\title{
Tania Leme de Almeida
}

\section{ESTUDO DA ATENUAÇÃO DOS CONTAMIINANTES IDE LIIQUUIDOS PERCOLADOS NO SOLO}

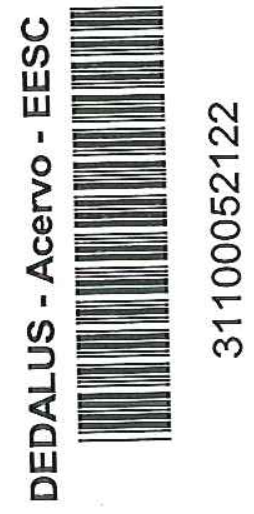

Dissertação apresentada à Escola de Engenharia de São Carlos da Universidade de São Paulo, como parte dos requisitos para obtenção do Título de Mestre em Hidráulica e Saneamento.

Orientador: Prof. Assoc. VALDIR SCHALCH

São Carlos 


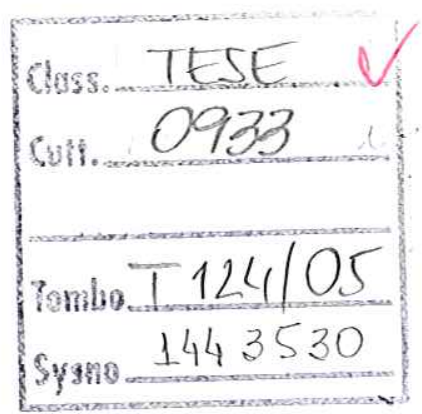

Ficha catalográfica preparada pela Seção de Tratamento da Informação do Serviço de Biblioteca - EESC/USP

Almeida, Tania Leme de
Es47e Estudo da atenuação dos contaminantes de líquidos percolados no solo / Tania Leme de Almeida. -- São Carlos, 2005.

Dissertação (Mestrado) -- Escola de Engenharia de São Carlos-Universidade de São Paulo, 2005.

Área: Hidráulica e Saneamento.

orientador: Prof. Assoc. Valdir Schalch.

1. Resíduos sólidos. 2. Aterro sanitário. 3. Líquidos percolados. 4. Solo. 5. Metal pesado. 6. Atenuação natural. I. Título. 
FOLFA DE JULGAMENTO

Candidato: Engenheira TANIA LEME DE ALMEIDA

Dissertação defendida e julgada em 23-03-2005 perante a Comissão Julgadora:

Prof. Associado VALDIR SCHALCH (Orimitador)

A PROVADO

(Escola de Engenharia de São Carlos/USP)

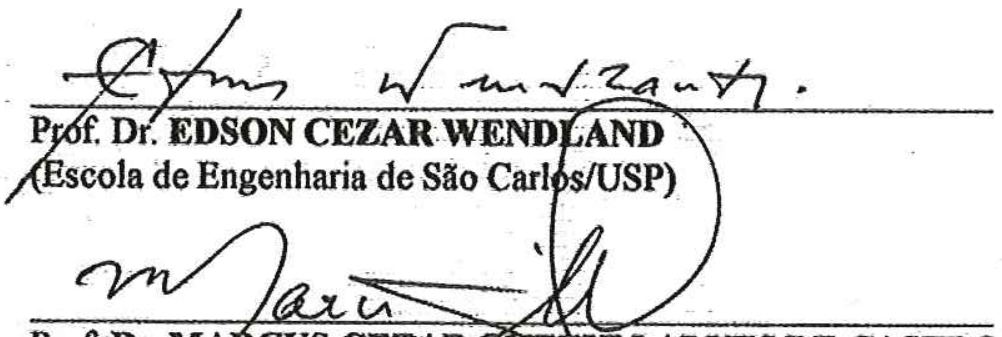

Prof: Dr. MARCUS CEZAR A TSSUM ALVES DE CASTRO

(Centro Universitário de Araraquara/UNIARA)

Ayrooado
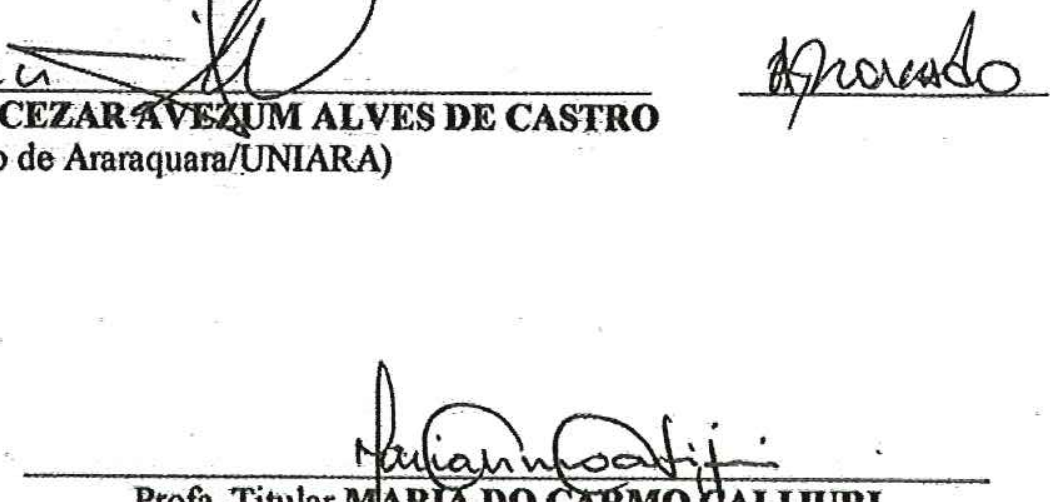

Profa. Titular MARIA DO CAKMO OALIJURI

Coordenadora do Programa de Pós-Graduaçăo em

Engenharia (Hidráulica e Saneamento) e

Presidente da Comissão de Pós-Graduação 
Aos meus pais, Edélcio e Sonia, em especial, pela compreensão, paciência, ajuda e exemplo de vida. 
A Deus que me deu força e luz para trilhar esse caminho;

Ao PPG-SHS que possibilitou a realização do presente estudo;

Ao Conselho Nacional de Pësquisa (CNPq) pela bolsa de estudo concedida;

À. Fundação de Amparo a Pesquisa do Estado de São Paulo (FAPESP) pelo auxílio à pesquisa concedida;

Ao Prof. Valdir Schalch pela oportunidade, confiança e orientação durante o desenvolvimento do presente estudo;

Aos amigos Adriana Antunes Lopes e Ronan Cleber Contrera pela amizade, dedicação e orientação fornecida durante todo o desenvolvimento do estudo;

Ao técnico Níbio José Mangerona do Laboratório de Polímeros do Instituto de Física de São Carlos, pela amizade e ajudä durante os momentos difíceis;

Aos técnicos do Laboratório de Saneamento do Departamento de Hidráulica e Saneamento, Paulo Fragiacomo, Júlio César Trofino, Maria Aparecida P. Viudes e, em especial, à Juliana Gonçalves dos Santos, pelo carinho e ajuda prestada durante as análises;

Aos Professores Edson César Wendland e Marcus César Avezum Alves de Castro, pelas valiosas sugestões durante o desenvolvimento deste estudo;

Ao Prof. Osni Pejon; por permitir o uso do Laboratório de Geologia do Departamento de Geotecnia, para. execução das análises e recomendações sobre a caracterização do solo;

Ao técnico Antônio Garcia do Eaboratório de Geologia do Departamento de Geotecnia, pelo auxílio dedicado durante as análises para caracterização do solo;

Ao Prof. Frederico Fábio Mauad pela concessão do espaço para montagem do experimento do laboratório e.por todo auxílio prestado;

Aos técnicos Waldomiro Antonio Filho, José Roberto Maramarque e, demais colegas do Núcleo de Hidrometria do Centro de Recursos Hídricos e Ecologia Aplicada (CRHEA) pelo auxílio, amizade e principalmente, por fazeram os dias no laboratório mais alegres;

Ao funcionário do CRHEA; Sr. Maurício Vizioli ,por toda atenção e ajuda;

A todos os funcionários do SHS-EESC-USP; 
As colegas Denise Conceição de Góis Santos, Monique Toledo Salgado e Karina Querne de Carvalho pela amizade, ajuda e incentivo;

A Professora Maria do Carmo Calijuri pela confiança e ajuda;

As secretárias da Pós Graduação do Departamento de Hidráulica e Saneamento, Maria Auxiliadora de C. Altieri Pin (Sá) e Pavlovna Damião Rocha Bueno (Pavi) pelo auxílio durante todo o curso de pós-graduạção; momentos;

Aos meus irmãos, Fábio e Rodrigo, e à Nina, pelo amor e carinho em todos os

A José Marcos Garrido Beraldo toda minha gratidão, pelo amor, carinho, dedicação e incentivo nesta fase da minha vida;

A TODOS que me ajudaram a concluir essa etapa....

Muito obrigada! 
"Senhor, conceda-me serenidade necessária para aceitar as coisas que não posso mudar, coragem para mudar as coisas que posso e sabedoria para distinguir umas das outras" 


\section{RESEGMO}

ALMEIDA; T. L. de (2005) Estudo da atemação dos contaminantes de líquidos percolados no solo. Dissertação (Mestrado) - Escola de Engenharia de São Carlos, Universidade de São Paulo, São Carlos, 2005.

A maioria dos municípios brasileiros dispõe os resíduos sólidos domiciliares em locais a céu aberto, sem controle e critério, contribuindo para a poluição das águas superficiais e do lençol freático. Estudos da.contaminação de solos e seus mecanismos são cada vez mais explorados devido à necessidade de segurança, a longo prazo, exigida para sistemas de contenção de resíduos. A movimentação de chorume dos aterros para os solos, águas superficiais e subterrâneas coloca em risco a saúde pública pela contaminação. Estudos recentes constataram a existência de processos que permitem a atenuação natural dos contaminantes presentes nestes percolados. $\mathrm{O}$ adequado entendimento destes processos pode dar origem a uma série de benefícios possíveis de serem aplicados em aterros antigos, novos ou naqueles que ainda serão concebidos. $\mathrm{O}$ presente trabalho avaliou a atenuação de contaminantes, presentes no chorume, pelo solo por meio de experimento desenvolvido em colunas de percolação. O chorume e o solo utilizados neste experimento são provenientes do aterro sanitário de São Carlos SP $\Theta$ solo utilizado foi caracterizado quanto à composição físico-química para verificar o transporte do percolado nas colunas e a interação solo-contaminante. As curvas características do transporte de contaminantes traçadas apresentaram baixas concentrações de $\mathrm{Pb}$ (Chumbo), Cd (Cádmio), Fe (Ferro), Zn (Zinco) e Mn (Manganês) nas amostras efluentes. Já o Na (Sódio), K (Potássio), Cl (Cloro), Ni (Níquel) e Cu (Cobre) foram preferencialmente lixiviados com o chorume percolante, evidenciando a variação da faixa de concentração de cada elemento no percolado. Os perfis de concentração dos metais pesados mostraram que existe uma frente de contaminação, apresentando uma relação entre a concentração do metal sorvido no solo e sua concentração no percolado. As curvas de retenção de metais no solo mostraram que o $\mathrm{Cd}, \mathrm{Pb}, \mathrm{Cr}, \mathrm{Cu}$ e $\mathrm{Mn}$ foram preferencialmente sorvidos no solo em relação ao $\mathrm{Fe}, \mathrm{Zn}$ e Ni. O solo em questão apresentou bom potencial para retenção dos contaminantes presentes no chorume, apesar de ser classificado como arenoso e de suas características químicas não se enquadrarem nos parâmetros adequados para sua utilização em áreas de disposição de resíduos : sólidos urbanos. Seu uso em base de aterros sanitários de pequeno porte pode ser considerado, desde que suas características sejam melhoradas por meio da mistura com geossintéticos. Este procedimento acarreta certa economia na construção de camadas impermeabilizantes, pois dispensa o uso de argilas e evita seu transporte de locais distantes do aterro.

Palavras-chave: Resíduos Șólidos; Aterro Sanitário; Líquidos Percolados; Solo; Metal Pesado; Atenuação Naţural. 


\section{ABSFRACT}

AEMEIDA, T. L. de (2005). Study the pollutants attemuation of the leachate in the soil. M. Sc. Dissertation - Escola de Engenharia de São Carlos, Universidade de São Paulo, São Carlos,2005.

The most of Brazilian municipal cities disposes solid waste in places at opened sky, without control and criterion, contributing to the pollution of the surface and groundwater. Studies concerning soil contamination and their mechanisms have been explored more and more due to the long term security requirements demanded for residue containment systems: The movement of leachate from the landfill to the soils, surface and groundwaters put on risk the public health because of the contamination. Recent studies verify the existence of processes that allow the attenuation in natural way of the present pollutants in these leachates. The appropriate understanding of these processes propitiates a series of possible benefits of they be applied in old landfill, new or in those that will be implanted. The present work evaluated the attenuation of pollutants, presents in the leachate by the soil through experiment developed in percolation columns. The leachate and soil used in this experiment have came from the sanitary landfill of São Carlos - SP. The collected soil was characterized as to composition physical-chemical to verify the transport of the leachate in the columns and the interaction soil-pollutant. The breakthrough curves traced have been observed that $\mathrm{Pb}$ (Lead), $\mathrm{Cd}$ (Cadmium), $\mathrm{Fe}$ (Iron), $\mathrm{Zn}$ (Zinc) and Mn (Manganese) came in low concentration in the effluents leachate. Already the Na (Sodium), K (Potassium), Cl (Chlorine), Ni (Nickel) and Cu (Copper) have been preferably leached with the leachate, showing accurrence of a wide range of concentrations of each species at leachate. Concentration profiles of the heavy metals indicated the existence of a contamination plume, showing relationship between concentration of the metal absorved in the soil and in the leachate. The curves of material's retention for the soil showed that the $\mathrm{Cd}, \mathrm{Pb}$, $\mathrm{Cr}, \mathrm{Cu}$ and $\mathrm{Mn}$ were preferably absorved by the soil in relation to the $\mathrm{Fe}, \mathrm{Zn}$ and $\mathrm{Ni}$. The soil in subject has presented good potential of retention for the present pollutants in the leachate in spite of being classified as sandy and they chemical characteristics don't frame in the appropriate parameters for use in areas of solid waste disposal. Your use in base of sanitary landfill of small load can be considered, since your characteristics have been improved through the mixture of this soil with geo synthetics, involving certain economy at construction of waterproof layers; ; exempting the clay use and avoid the transport of this material for distant places of the landfill.

Keyswords: Solid waste; Sanitary Landfill; Leachate; Soil; Heavy metals; Natural attenuation 


\section{GISTRA DE FIGURAS}

FIGURA 1 - Variação de parâmetros selecionados, indicadores das fases de estabilização da matéria orgânica em um aterro sanitário.

FIGURA 2 - Variação da concentração do efluente - Curva Característica de Transporte ou Breakthrough curve.

FIGURA 3 - Aterro Sanitário de São Carlos: Local de coleta do solo.

FIGURA 4 - Solo coletado na base do aterro (amostras deformadas).

FIGURA 5 - Solo coletado na base do aterro (amostras indeformadas).

FIGURA 6 - Secagem do solo amostrado.

FIGURA 7 - Curva Granulométrica do solo amostrado......................................... 50

FIGURA 8 - Diagrama Triangular para definição da classe textural do solo.

FIGURA 9 - Partes estruturais das colunas para o teste de percolação. 55

FIGURA 10 - Local de coleta de chorume para percolação das colunas: Caixa de acúmulo do Aterro Sanitário de São Carlos.

FIGURA 11 - Amostra de chorume analisado antes da percolação nas colunas.

FIGURA 12 - Acondicionamento do chorume coletado..

FIGURA 13 - Curvas de variação da Condutividade elétrica em função do número de vazios percolados (VP) para as Colunas 1 e $2 \ldots \ldots \ldots \ldots \ldots \ldots \ldots \ldots \ldots \ldots \ldots . . . . . . . . . . . . . . .66$

FIGURA 14 - Curvas de variação do Potencial hidrogeniônico em função do número de vazios percolados (V.P) para as Colunas 1 e 2 .

FIGURA 15 - Curva de variação do Potencial elétrico em função do número de vazios percolados.(VP) para as Colunas 1 e 2

FIGURA 16 - Curva de variação da Turbidez em função do número de vazios

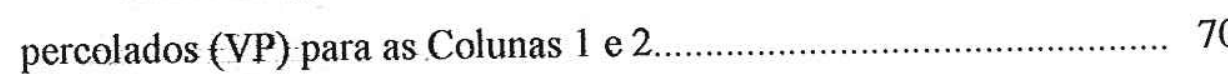

FIGURA 17 - Curva de variação da Demanda Química de Oxigênio em função do número de vazios percolados (VP) para as Colunas 1 e $2 \ldots \ldots \ldots \ldots \ldots \ldots . . .71$

EIGURA 18 - Curvas de transporte para $\mathrm{Pb}, \mathrm{Cd}$ e $\mathrm{Fe}$ versus número de vazios percolados (VP) versus $\mathrm{pH}$ do chorume efluente nas Colunas 1 e $2 \ldots . .75$

FIGURA 19 - Curvas de transporte para $\mathrm{Na} \mathrm{K}$ e $\mathrm{Cl}$ versus número de vazios percolados (VP) versus $\mathrm{pH}$ do chorume efluente nas Colunas 1 e $2 \ldots . .77$ 
FIGURA 20 - Curvas de transporte para $\mathrm{Zn}$ e Mn versus número de vazios percolados (VP) versus $\mathrm{pH}$ do chorume efluente nas Colunas 1 e $2 \ldots . .79$

FIGURA 21 - Curvas de transporte para $\mathrm{Cu}$ e $\mathrm{Ni}$ versus número de vazios percolados (VP) versus $\mathrm{pH}$ do chorume efluente nas Colunas 1 e $2 \ldots . .80$

FIGURA22 - Perfil de distribuição de metais após 5,0 volumes de poros percolados com chorume na Coluna 1

FIGURA 23 - Perfil de distribuição de metais após 5,0 volumes de poros percolados com chorume na Coluna 2 .

FIGURA 24 - Perfil de distribuição de metais após 5,0 volumes de poros percolados com água na Coluna 3 


\section{HSTA DE QUADROS}

QUADRO 1 - Processos físicos, químicos e biológicos que controlam a migração de contaminantes........................................................ 16

QUADRQ:2 - Principais fontes antropogênicas de emissão de metais pesados.

QUADRO 3 - Minerais primários e respectivos elementos metálicos pesados que o solo pode fornecer.

QUADRO 4 - Adsorção seletiva de metais pesados em diferentes solos......

QUADRO 5 - Variáveis físicas e químicas analisadas com os métodos utilizados e respectivas referências. 


\section{LISTA DE TABELAS}

TABELA.1 - Superficie específica e capacidade de troca catiônica dos principais componentes das frações argila, silte e areia.

TABELA2 - Propriedades físicas do solo amostrado. 48

TABELA 3 - Parâmetros físicos calculados do solo. 48

TABELA 4 - Propriedades químicas do solo estudado.

TABELA 5 - Valores da CTC e SE do solo estudado, conforme a massa da amostra e o volume de azul de metileno empregado.

TABELA 6 - Valores de $\Delta \mathrm{pH}_{\mathrm{H} 2 \mathrm{O}}, \Delta \mathrm{pH}_{\mathrm{KCl}}, \Delta \mathrm{pH}$ e $\mathrm{pH}_{0}$ para o solo analisado.

TABELLA 7 - Concentração de metais pesados no solo coletado, em condições naturais (condições de campo)

TABELA 8 - Composição da água coletada do poço de uso regular do CRHEA antes do início da percolação nas colunas experimentais

TABELA 9 - Caracterização do chorume percolado antes e depois da acidificação e enriquecimento com soluções salinas de $\mathrm{Cr}, \mathrm{Pb}$, $\mathrm{Cu}, \mathrm{Mn}, \mathrm{Zn}$ e $\mathrm{Cd}$.

TABELA 10 - Comparação dos dados obtidos na caracterização do solo versus aspectos utilizados na seleção de áreas para localização de aterros sanitários

TABELA 11 - Comparação dos valores orientadores para solos do Estado de São Paulo versus :- solo do aterro sanitário de São Carlos 


\section{EISTA DE SIGLAS}

ABNT - ... Associação Brasileira de Normas Técnicas

APHA - _.. American Public Health Association

ASTM - American Society for Testing and Materials

CETESB - Companhia de Tecnologia de Saneamento Ambiental

CRHEA - Centro de Recursos Hídricos e Ecologia Aplicada

EESC - Escola de Engenharia de São Carlos

IPT - Instituto de Pesquisa Tecnológica do Estado de São Paulo

IBGE - - Instituto Brasileiro de Geografia e Estatítica

NBR - : Norma Brasileira Registrada

NEPER - - Núcleo de Estudo e Pesquisa em Resíduos Sólidos

USP- - Universidade de: São Paulo 
LISTA DE: SÍMBOHOS

$\% \mathrm{C}$ - Porcentagem de Carbono

$\rho$-... Massa Especiffica do Solo $\left(\mathrm{M} / \mathrm{L}^{3}\right)$

$\rho \mathrm{d}$ - $\quad$ Massa Específica Seca:do.Solo $\left(\mathrm{M}_{\mathrm{L}} \mathrm{L}^{3}\right)$

$\rho \mathrm{s}$ - $\quad$ Massa Específica dos Sólidos do:Solo $\left(\mathrm{M} / \mathrm{L}^{3}\right)$

UT-... Unidade de Turbidez

$\mu \mathrm{g}-\quad$ Micrograma

AVT - Ácidos Voláteis Tpotal

$\mathrm{Ca}$ - Cálcio

$\mathrm{CaCO}_{3}$ - Cärbonato de Cálcio

Cd- Cádmio

$\mathrm{CdCl}_{2}$ - Cloreto de Cádmio

Ce-Concentraęão Eflụente

CE- Condutividade Elétrica

$\mathrm{CH}_{4}-$ Metano

$\mathrm{Cl}$ - Cloro/Cloreto

$\mathrm{cm}^{3}$ - Centímetro Cúbico

cmol-Centimol

Co- Concentração:Inicial ou Inflụente

$\mathrm{CO}_{2}$ - Dióxido de Carbono

$\mathrm{CO}_{3}^{2-}$ Carbonato

COT - Carbono Orgânico Total

Cr-... Cromo

CTC - Capacidadede Traca de Cátions

$\mathrm{Cu}$ - Cobre

DBO - Demanda Bioquímica de Oxigênio

DQO - Demanda Química de Oxigênio

e-. Índice de Vazios

Eh - Potencial de Oxi-redụção

$\mathrm{Fe}-\quad$ Ferro

g- Grama

$\mathrm{H}^{+}$- Íon Hidrogênio

$\mathrm{H}_{2}$ - Gás Hidrogênio 


\begin{tabular}{|c|c|}
\hline $\mathrm{H}_{2} \mathrm{O}-$ & Água \\
\hline $\mathrm{HCl}-$ & Ácido Clorídrico \\
\hline $\mathrm{HCO}^{3-}-$ & Bicarbonato \\
\hline $\mathrm{K}-$ & Potássio \\
\hline $\mathrm{KCl}-$ & Cloreto de Potássio \\
\hline $\mathrm{Kg}=$ & Quilograma \\
\hline $\mathrm{L}-$ & Litro \\
\hline$M-$ & Molar \\
\hline$m^{2}-$ & Metro Quadrado \\
\hline meq- & Miliequivalente \\
\hline $\mathrm{mg}=$ & Miligrama \\
\hline $\mathrm{Mg}-$ & Magnésio \\
\hline $\mathrm{Mn}-$ & Manganês \\
\hline $\mathrm{mS}-$ & Micro Simens \\
\hline $\mathrm{mV}-$ & Milivolt \\
\hline $\mathrm{N}-$ & Normal \\
\hline$n-$ & Porosidade \\
\hline $\mathrm{N}_{2-}-$ & Gás Nitrogênio \\
\hline $\mathrm{Na}-$ & Sódio \\
\hline $\mathrm{Ni}-$ & Níquel \\
\hline $\mathrm{O}_{2}$ & Gás Oxigênio \\
\hline OD - & Oxigênio Dissolvido \\
\hline $\mathrm{OH}^{-}-$ & Hidroxila \\
\hline $\mathrm{Pb}-$ & Chumbo \\
\hline $\mathrm{pH}-$ & Potencial Hidrogeniônico \\
\hline ppm - & Parte por Milhão \\
\hline $\mathrm{SE}-$ & Superfície Específica \\
\hline $\mathrm{SO}_{4}-$ & Sulfato \\
\hline $\mathrm{Sr}-$ & Grau de Saturação \\
\hline UNT - & Unidade de Turbidez \\
\hline $\mathrm{VP}-$ & Volume de Poros \\
\hline $\mathrm{Vv}-$ & Volume de Vazios \\
\hline$w-$ & Umidade \\
\hline
\end{tabular}


Zn- Zinco 


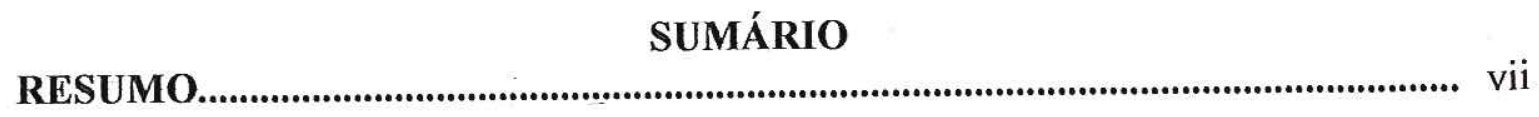

ABSTRACT................................................................................................................ viii

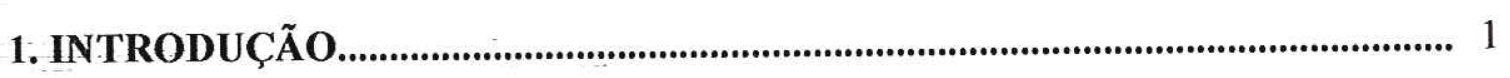

2. REVISÃO BIBLIOGRÁFICA.............................................................................. 5

2.1.Resíduos Sólidos................................................................................... 5

2.2.Sistema de disposição final de Resíduos Sólidos.................................................. 7

2.2.1.Lixão

2.2.2.Aterro Controlado

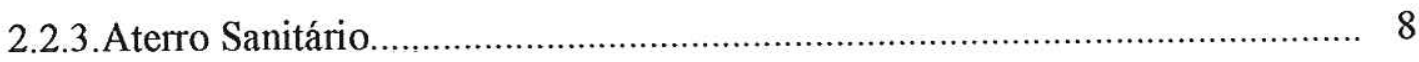

2.3.Líquidos Percolados

2.4.Poluição e Contaminação do Solo e da Água Subterrânea........................................ 11

2.5.Aspectos Geológicos a serem considerados na localização de Aterro Sanitário....... 13

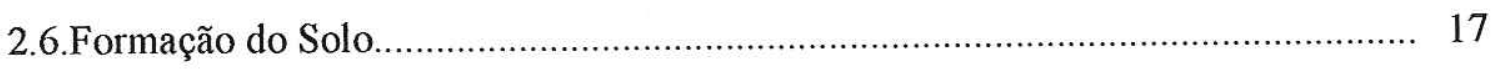

2.6.1.Solo como atenuador natural ....................................................................... 18

2.7.Metais pesados no solo .......................................................................... 19

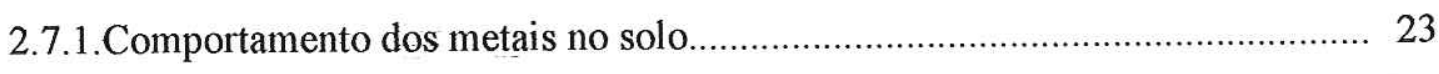

2.7.2.Retenção de metais pesados....................................................................... 26

2.7.3.Características de alguns metais................................................................. 28

2.8.Transporte de Contaminantes em Meio Poroso …………...................................... 34

2.8.1.Mecanismos físicos de transporte ............................................................ 34

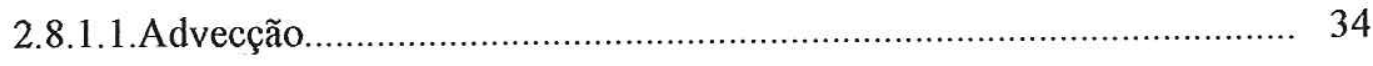

2.8.1.2.Dispersão Hidrodinâmica............................................................... 35

2.8.2. Mecanismos químicos que influenciam o transporte ................................... 36

2.8.2.1.Sorção/Dessorção............................................................................ 37

2.8.2.2.Troca Iônica ............................................................................. 38

2.8.2.3.Complexação, Precipitação, Reações Redox e Ácido/Base.................. 40

2.9.Ensaios de Coluna ......................................................................................... 41

2.10.Considerações finais.................................................................................... 43

3. METODOLOGIA................................................................................................... 45

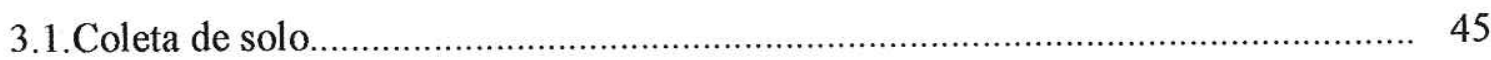

3.2.Caracterização física do solo............................................................................. 48

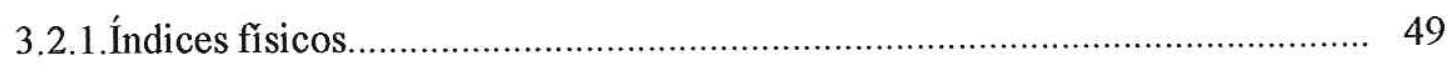

3.2.1.1.Massa específica dos sólidos............................................................ 49 


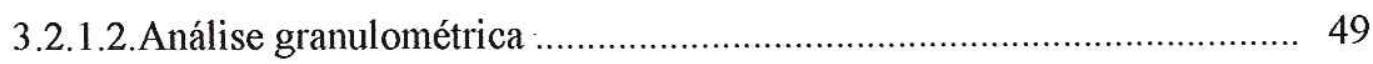

3.3. Caracterização química do solo..................................................................... 51

3.3.1.Determinação da CTC e SE .................................................................... 51

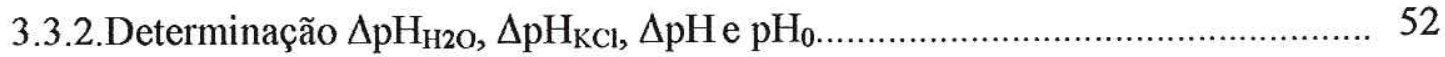

3.3.3.Determinação da condutividade elétrica....................................................... 53

3.3.4. Determinação dos teores de metais pesados............................................... 54

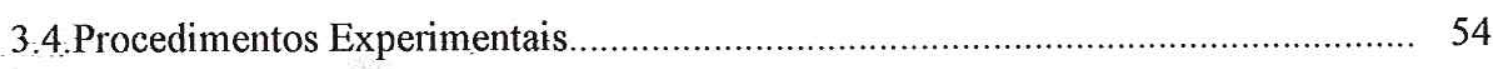

3.4.1.Montagem das colunas......................................................................... 54

3.4.2.Saturação das colunas de solo...................................................................... 56

3.4.3. Coleta do chorume

3.4.4.Preparo do chorume para início do teste de percolação................................. 58

3.4.5.Coleta de amostras efluentes....................................................................... 60

3.4.6.Desmontagem das colunas experimentais ............................................. 61

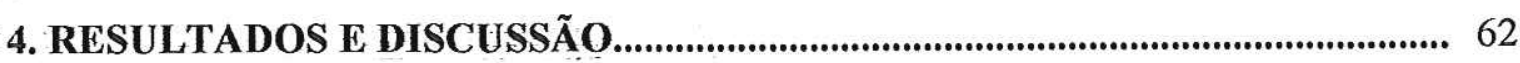

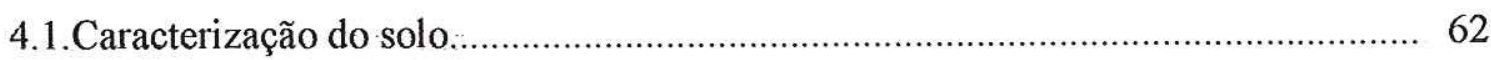

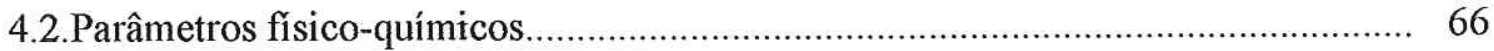

4.3.Curvas características de transporte de contaminantes.......................................... 73

4.4.Perfil de retenção de contaminantes inorgânicos pelas colunas de solo................... 81

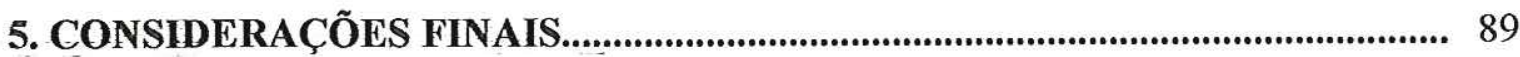

6. SUGESTÕES PARA TRABALHOS FUTUROS................................................ 91

7. REFERÊNCIAS BIBLIOGRÁFICAS............................................................. 92

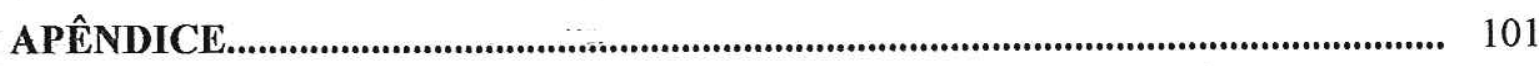




\section{INTRODUÇÃO}

Os esforços para a disposição segura dos resíduos gerados pelo homem têm sido ineficazes, principalmente porque não acompanham o crescimento de sua produção e, assim, a disposição inadequada de resíduos no solo, com conseqüente contaminação das águas superficiais e subterrâneas, é reconhecida como um dos graves problemas da atualidade. Os efeitos do lançamento dos rejeitos na natureza são incalculáveis e recaem na escassez e contaminação da água e no aumento das doenças associadas à poluição ambiental.

Entre as técnicas de disposição final de resíduos sólidos, os aterros sanitários são os que apresentam maior custo, principalmente quando se dispõe de áreas apropriadas. Apesar da disposição direta dos resíduos no solo ser uma forma corrente de disposição para a maioria dos municípios brasileiros, poucos estudos têm sido conduzidos para avaliar os efeitos provocados pelo percolado ou chorume, que se infiltra no solo.

A decomposição dos resíduos sólidos em locais de disposição destes materiais ocorre devido a ação microbiana. O produto da biodegradação dos resíduos somado à água que infiltra nas células forma o líquido chamado de chorume ou percolado. As características físico-químicas e microbiológicas do percolado variam em função da origem e idade dos resíduos originalmente dispostos, bem como da fase de decomposição do processo. De forma geral, este percolado contém, em concentrações variadas, compostos orgânicos, inorgânicos, além de metais pesados que podem contaminar o meio ambiente e ser tóxico aos seres vivos.

A poluição das camadas saturadas do solo ocorre geralmente devido à localização dos lixões e aterros em ambientes geológicos desfavoráveis e também devido à forma inadequada de disposição de resíduos. Deve-se ter o conhecimento geológico e hidrogeológico do local onde os resíduos serão dispostos e também das características dos poluentes, pois permitirá determinar o comportamento destes no meio físico, visto que o chorume pode percolar pelo solo, atingindo os recursos hídricos 
superficiais e/ou subterrâneos promovendo sua contaminação e o provável comprometimento.

A maioria dos estudos não fornece subsídios para determinar qualitativamente os efeitos sobre o solo e sobre o próprio líquido que escoa pelo meio poroso. Em função das indefinições encontradas, verifica-se que há uma tendência nas condutas estabelecidas por órgãos ambientais na adoção de sistemas confinantes, que acaba inviabilizando soluções para os pequenos municípios, devido à necessidade do emprego de geomembranas para impermeabilização dos respectivos aterros sanitários. Assim, quanto maiores as exigências técnicas, menores serão as possibilidades de um pequeno município atenda-as integralmente, podendo se transformar em sistema desordenado de disposição de resíduos.

Assim, sistemas de impermeabilização são requeridos para a construção de aterros de resíduos sólidos devido ao elevado potencial poluente do percolado e ao fato de minimizarem a contaminação ambiental, mas são caros e oneram o custo de construção das células dos aterros.

Uma solução intermediária para restringir o escoamento do chorume para os aqüíferos subterrâneos é a utilização de um solo adequado em sua base, de forma que apresente baixa permeabilidade. Assim, o conhecimento dos processos envolvidos nesse escoamento, através das condições de permeabilidade natural do solo, permitiria estabelecer quais parâmetros deveriam ser avaliados para viabilizar ambientalmente as instalações, e também definir potencialmente sua capacidade de confinar e atenuar os eventuais impactos sobre o solo.

McBean et al. (1995) descrevem que os solos apresentam um sistema complexo e dinâmico em que interagem continuamente os processos físicos, químicos e biológicos. O solo é um sistema: heterogêneo e polidisperso de componentes sólidos, líquidos e gasosos, em diversas proporções, sendo que é também bastante poroso e pode apresentar água em seus interstícios, que se constitui como meio solvente. Os solos são constituídos de substâncias de alta ou baixa solubilidade, de uma grande variedade de compostos orgânicos e de organismos vivos e, ainda, apresentam um meio favorável no qual ocorrem atividades biológicas complexas de forma simultânea.

A força de interação e a predominância de uma reação sobre outra é controlada pelos constituintes específicos do solo, assim as interações solo-chorume e as reações físico-químicas envolvidas durante a percolação, resultam na atenuação da carga de 
contaminantes do chorume... Esse processo de atenuação resulta na redução da concentração de contaminantes durante o respectivo transporte através do solo.

As principais formas de atenuação são mecanismos físicos (filtração, difusão e dispersão e absorção), químicos (precipitação/dissolução, adsorção/dessorção, complexação, troca iônica e reações de redox) e microbiológicos (biodegradação aeróbia e anaeróbia) (YONG etal., 1992).

Estudos atuais indicam a possibilidade de atenuação natural dos contaminantes do chorume a partir da sua percolação em solos, onde foi verificada em solos constituídos de material arenoso (CHRISTENSEN et al., 2001). Apesar das evidências sobre a atenuação natural, ainda não foram conduzidos estudos suficientes que investiguem as diversidades, mecanismos, taxas e fatores governantes deste processo. Dessa forma, muitas de suas aplicações continuam sendo desconsideradas (CHRISTENSEN et al.,2001).

O objetivo principal deste estudo foi avaliar o transporte do líquido percolado no solo do aterro sanitário do município de São Carlos e verificar a atenuação dos contaminantes, principalmente os metais pesados, presentes neste líquido.

Para tal, os parâmetros físico-químicos do solo foram avaliados através das curvas de variação da Condutividade Elétrica (CE), Potencial hidrogeniônico $(\mathrm{pH})$, Potencial Elétrico ou Redox (Eh), Turbidez e Demanda Química de Oxigênio (DQO) em função do número de volume de poros (ou de vazios) percolados (VP). As Curvas Características de Transporte dos pontos de concentrações relativas (Concentração efluente/Concentração inicial - $-\mathrm{Ce} / \mathrm{Co}$ ) dos contaminantes presentes no chorume percolante $-\mathrm{Zn}, \mathrm{Pb}, \mathrm{Cd}, \mathrm{Fe}, \mathrm{Mn}, \mathrm{Cu}, \mathrm{Na}, \mathrm{K}, \mathrm{Ni}$ e $\mathrm{Cl}$ - versus o número de poros percolados (VP) foram traçadas. E, também os perfis de concentração dos metais pesados através das curvas de retenção (para $\mathrm{Cd} ; \mathrm{Pb}, \mathrm{Cu}, \mathrm{Fe}, \mathrm{Zn}, \mathrm{Mn}, \mathrm{Ni}$ e $\mathrm{Cr}$ ) foram obtidas por meio de teste de percolação em colunas após 5,0 VP percolados com chorume.

Assim, para elaboração desta dissertação procurou-se reunir os assuntos relevantes ao tema, abrangendo alguns conceitos importantes, muitas vezes básicos.

Inicialmente foram apresentadas a definição de resíduos sólidos e as formas de disposição destes, além de alguns aspectos sobre contaminação e poluição de águas e solos, como o comportamento dos metais no solo. Em seguida, foram apresentados os principais mecanismos de transporte e atenuação de contaminantes no meio poroso, bem como os aspectos fundamentais a serem considerados em ensaios de colunas. 
Os capítulos seguintes foram dedicados ao experimento efetuado, englobando a caracterização do solo coletado, montagem das colunas experimentais, os aspectos metodológicos e, por último, os resultados e conclusões dos experimentos.

Como finalização, foram apresentadas as considerações finais e sugestões para trabalhos futuros. 


\section{REVISÃO BIBLIOGRÁFICA}

\subsection{RESÍDUOS SÓLIDOS}

O aumento populacional e o avanço da tecnologia estão trazendo à tona um problema que se agrava a todo o momento, a produção de "lixo", que é uma conseqüência inevitável do dia-a-dia. $\mathrm{O}$ volume produzido está aumentado de forma rápida e sua velocidade de produção é maior que a de degradação. O Estado de São Paulo; que possui 645 municípios e uma população de aproximadamente 37 milhões de habitantes (SÃO PAULO, 2004) produz cerca de 25.856 toneladas desses resíduos por dia, sendo que $63 \%$ são dispostos a céu aberto, $18,4 \%$ são dispostos em aterros controlados e 13,8\% em aterros sanitários (IBGE, 2002).

Todo esse resíduo sólido produzido preocupa as autoridades e pesquisadores do assunto devido à dificuldade de obtenção de locais adequados para seu destino e também devido aos danos ambientais que podem causar. Assim, a enorme quantidade de resíduos sólidos produzidos não constituem apenas problema estético, mas também uma ameaça ao homem e ao meio ambiente, esgotando rapidamente os espaços úteis disponíveis para a disposição desses resíduos produzidos.

No Brasil, os resíduos sólidos seguem os critérios estabelecidos pela Associação Brasileira de Normas Técnicas (ABNT), a qual apresenta uma relação de normas: NBR 10004 (2004) Resíduos Sólidos - Classificação; NBR 10005 (2004) Procedimento para obtenção de extrato lixiviado de resíduos sólidos; NBR 10006 (2004) Procedimento para obtenção de extrato solubilizado de resíduos sólidos; NBR 10007 (2004) Amostragem de resíduos sólidos; NBR 8419 (1992) Projetos de aterros sanitários de resíduos sólidos urbanos, entre outras.

Resíduos Sólidos são aqueles os quais se encontram nos estados sólidos e semisólidos e resultam de atividades de origem industrial, doméstica, hospitalar, comercial, agrícola, de serviços e de varrição. Estão inseridos os lodos provenientes de sistemas de tratamento de água e os gerados em equipamentos e instalações de controle de poluição, 
e-também determinados líquidos cujas particularidades não permitem o seu lançamento na rede pública de esgotos ou corpos de água, ou exijam para isso soluções técnica e economicamente inviáveis em face à melhor tecnologia disponível (NBR 10004 ABNT, 2004).

Através da NBR 10004 (ABNT, 2004), a ABNT classifica os resíduos sólidos conforme seu grau de periculosidade: Resíduos Classe I - Perigosos e Resíduos Classe II - Não Perigosos (resíduos Classe II A - Não Inertes e resíduos Classe II B - Inertes). Os resíduos radioativos possuem legislação específica e o seu gerenciamento é de responsabilidade da Conselho Nacional de Energia Nuclear (CNEN) não se enquadrando nesta classificação.

Conforme BIDONE e POVINELLI (1999), a composição dos resíduos sólidos domiciliares varia muito em função dos hábitos culturais, sociais e da situação econômica da população. Portanto, os resíduos sólidos podem ser classificados em fưção da fonte de origem cọmo:

- Urbanos: Incluem os resíduos domiciliares e o comercial produzido em escritórios, supermercados, restaurantes, lojas e hotéis; e os de serviços provenientes da limpeza urbana; além dos resíduos de varrição, limpeza de galerias, terrenos, podas e capinação;

- Industriais: Correspondem aos resíduos gerados nos diversos tipos de indústrias de processamento;

- Serviços de Saúde: São os resíduos provenientes de farmácias, hospitais, unidades ambulatoriais de saúde; clínicas médicas e veterinárias, consultórios médicos e adontológicos, laboratórios de análises clínicas e patologias, instituições de ensino e pesquisa médica, bancos de sangue e outros estabelecimentos prestadores de assistência médica e-sanitária;

- Portos, Aeroportos, Terminais Rodoviários e Ferroviários: Constituem resíduos sépticos que contém ou podem conter germes patogênicos, tais como materiais de higiene e de asseio pessoal; restos de alimentos entre outros, e que podem veicular doenças provenientes de outras cidades, estados e países;

- Agrícolas: São os resíduos provenientes das atividades da agricultura e da pecuária, como embalagens de adubos, defensivos agrícolas, restos de colheita e esterco animal. A maior preocupação são as embalagens de agroquímicos, pelo seu alto grau de toxicidade, tendo legislação específica para tal;

- Entulho: Constitui resíduos de construção civil (demolições, restos de obras, solos de escavações, entre outrios). 
- Radioativos: São os resíduos provenientes do aproveitamento de combustíveis nucleares, e seu gerenciamento é de competência da CNEN.

\subsection{SISTEMAS DE-DISPOSIÇÃO FINAL DE RESÍDUOS SÓLIDOS}

Os-resíduos sólidos não são-prioridade dos planos de governo e essa postura dos administradores públicos se reflete no cenário brasileiro (LOPES, 2004). Dessa forma, os-lixões predominam como forma de disposição final dos resíduos sólidos urbanos na maioria dos municípios brasileiros, representando 63,6\%, conforme a Pesquisa Nacional de Saneamento Básico (IBGE, 2002). Os aterros controlados vêm em seguida, ocorrendo em $18,4 \%$ dos municípios e os aterros sanitários com a menor proporção, correspondendo a $13,8 \%$ dos municípios estudados (IBGE, 2002).

Observa-se uma tendência para confundir aterro sanitário com vazadouros, depósitos, lixões e demais métodos, que desprovidos de critérios científicos ou ecológicos são condenados do ponto de vista sanitário. Assim, os resíduos sólidos, principalmente os domiciliares, após serem recolhidos, seguem para local de disposição final que variam, de acordo com cada município, como descritos a seguir:

\subsubsection{LIXÃO}

O lixão é uma forma inadequada de disposição de resíduos sólidos, que representa a descarga deste material sobre o solo, sem medidas de proteção ao meio ambiente e à saúde pública. Esse lançamento pode acarretar problemas à saúde pública, por permitir a proliferação de insetos, roedores, geração de maus odores, poluição do solo e das águas superficiais e subterrâneas, através da percolação do chorume ou infiltração do percolado (IPT, 1995).

É o método mais utilizado pelos municípios brasileiros e a pior forma de disposição em todos os aspectos, mas $63,6 \%$ dos municípios ainda tem este método como forma de disposição final de seus resíduos sólidos urbanos (IBGE, 2002). 


\subsubsection{ATERRO CONTROLANDO}

É um método de disposição final de resíduos sólidos no solo, na qual se utiliza de princípios de engenharia para o confinamento dos resíduos sólidos, com cobertura diária de material inerte sobre os resíduos sólidos. Mas, aterros controlados não dispõem de impermeabilização de base, sistema de tratamento de chorume ou de dispersão dos gases gerados (ABNT, 1985).

\subsubsection{ATERRO SANITÁRIO}

Aterro Sanitário, segundo a NBR 8419/92 da ABNT, é uma técnica de dísposição de resíduos sólidos urbanos no solo, sem causar danos ou riscos à saúde pública e à segurança, minimizando os impactos ambientais. Este método utiliza princípios de engenharia para confinar os resíduos sólidos a menor área possível e reduzí-los ao menor volume permissível, cobrindo-os com uma camada de terra na conclusão de cada jornada de trabalho ou em intervalos menores se necessário.

Antes da implantação, o terreno a ser utilizado deverá passar por estudos criteriosos, considerando aspectos ambientais, sociais, econômicos e políticos, ou seja, aspectos voltados à saúde pública, topografia do local, sondagens, permeabilidade do solo, dados meteorológicos, zoneamento, legislação, vizinhança, custos e à circulação de veículos na região (OLIVEIRA, 2001).

Técnicas de engenharia e normas operacionais específicas são aplicadas para manter o confinamento seguro dos resíduos, como a presença de sistemas de drenagem periférica e superficial para transporte da água de chuva; drenagem de fundo para a coleta de lixiviado; sistemas de tratamento para o lixiviado drenado, bem como dissipadores e queima dos gases gerados durante o processo de bioestabilização da matéria orgânica (BIDONE e POVINELLI, 1999).

O estudo da biodegradação dos resíduos e monitoramento de alguns parâmetros em aterros sanitários mostram que a estabilização da matéria orgânica passa por diversas fases, surgindo vários modelos que representam este fato. POHLAND e 
GOULD (1986) ${ }^{1}$ apud SCHALCH(1992) apresentaram um modelo com cinco fases de estabilização da matéria orgânica, como ilustrado na FIGURA 1.

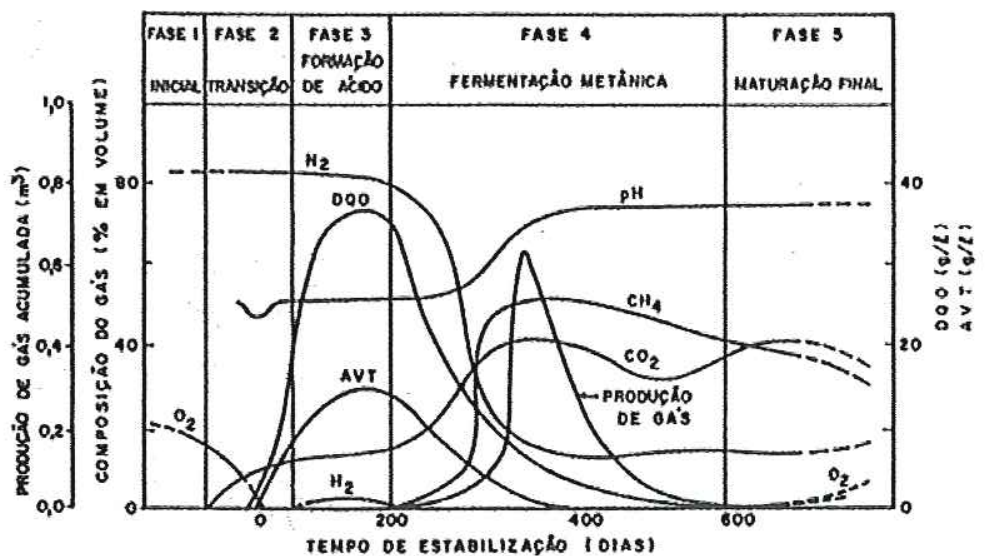

FIGURA 1 - Variação de parâmetros selecionados, indicadores das fases de estabilização da matéria orgânica em um aterro sanitário FONTE - POHLAND e GOULD (1986), apud SCHALCH (1992)

Na primeira fase, denominada de fase de ajustamento, as atividades do aterro sanitário são iniciadas e ocorre acumulação de umidade que favorece a realização das reações que proporcionam a produção de gás e líquidos percolados. A ação microbiana estimula a conversão dos resíduos e a estabilização com várias fases sucessivas, cada uma variando em intensidade e duração, de acordo com as condições operacionais predominąntes.

A-etapa seguinte, denominada de fase de adaptação inicial ou fase de transição, a capacidade de campo - limite máximo de umidade que um resíduo pode reter — é alcançada e a formação do gás e dos líquidos percolados refletem a passagem da condição aeróbia para a anaerọ́bia.

A fase 3 ou fase de formação de ácidos, define a predominância da formação de ácidos voláteis totais (AVT) com decréscimo nos valores do $\mathrm{pH}$, elevação da concentração da Demanda Química de Oxigênio (DQO) dos líquidos percolados e aumento da mobilidade das espécies iônicas.

A fase 4 ou fase de fermentação metanogênica, é acompanhada por uma produção adicional e conversão dos compostos intermediários, em metano e excesso de dióxido de carbono, além da redução da intensidade de formação de líquidos

\footnotetext{
${ }^{1}$ POHLAND e GOULD (1986) Co-disposal of municipal refuse and industrial waste sludge in landfilts: Hater Science Technology, v.18, n.12, p.177-192.
} 
percolados, aumento dos valores do $\mathrm{pH}$, abaixamento do potencial de oxidação-redução e uma acelerada complexação e redução das espécies iônicas.

$\mathrm{Na}$ fase 5 ou fase de maturação final, os nutrientes tornam-se escassos e uma menor quantidade de substratos disponíveis são degradados, a produção de gás decresce e os constituintes orgânicos e inorgânicos dos líquidos percolados apresentam condição de pós-estabilização.

\subsection{LÍQUHDOS PERCOLADOS}

Chorume ou sumeiro é o líquido produzido pela decomposição de substâncias contidas nos resíduos sólidos, de cor escura, mau cheiro e elevada Demanda Bioquímica de Oxigênio (DBO), formado pela digestão da matéria orgânica sólida, por ação de exoenzimas produzidas pelas bactérias. Essas exo-enzimas solubilizam a matéria orgânica para que possa ser assimilada pelas células bacterianas (SCHALCH, 1984).

A água da chuva, que cai sobre o aterro sanitário percola pelo lixo e carrega o chorume e a matéria orgânica, dando origem ao percolado ou lixiviado. A NBR 8419 (ABNT, 1992) define percolado, como o líquido que passa através de um meio poroso causando sérios problemas ambientais. A alta carga orgânica e a complexa composição desse líquido podem comprometer a qualidade de um manancial, seja através do deflúvio para corpos de água superficiais, ou através da infiltração em lençóis subterrâneos, já que a DBO dos líquidos provenientes de aterros sanitários é muito elevada, cerca de 30 a 100 vezes maior que o esgoto (COSTA LEITE et al., 1982 ${ }^{2}$, apud SCHALCH, 1984).

As características dos percolados variam de local para local, sazonalmente, e também ao longo da vida útil de um aterro, apresentando constantes mudanças no que se refere à vazão gerada, à composição química e à concentração. Portanto, seu volume e sua capacidade de lixiviação depende da quantidade de água e precipitação atmosférica que atinge os resíduos, da quantidade e qualidade da matéria orgânica e do tipo de solo, que em última análise pode permitir uma infiltração maior do chorume nas camadas mais profundas do solo (HEITZMANN Jr., 1999).

\footnotetext{
${ }^{2}$ COSTA LEITE et al., (1982) Avaliação da produção de percolado do lixo e da capacidade filtrante de aterros samitários. Revista Engenharia Sanitária, 21 (01), p.90-99.
} 
A composição química dos líquidos percolados varia com a idade do aterro sanitário. Análises de líquidos percolados, coletados durante a fase ácida da decomposição, mostram altos valores de DQO, DBO, nutrientes, metais pesados, além de baixos valores de $\mathrm{pH}$. Por autro:lado, líquidos percolados coletados durante a fase de fermentação metanogênica, apresentam valores de $\mathrm{pH}$ que podem estar na faixa de 6,5 a $7 ; 5$ e valores de DQO; DBO e nutrientes significativamente menores que os da fase ácida: Da mesma forma, as concentrações de metais pesados também são bem menores porque a maioria dos metạis $\cdot$ são menos solúveis em $\mathrm{pH}$ aproximadamente neutro (TCHOBANOGLOUS et al., 19993).

Os resíduos sólidos domiciliares gerados no Brasil contém mais de $50 \%$ de matéria orgânica, sendo que o confinamento e o não revolvimento desta proporciona o total consumo de oxigênio: pela ação bacteriana, dando início a decomposição anaeróbia. Assim, a maior parte da fração deste resíduo é passível de degradação biológica, o que torna inevitável a formação de percolado, como observado por SCHALCH (1984).

Os líquidos percolados são: aqueles que compõe a fase líquida do aterro e sua geração é função da interação de fatores como composição dos resíduos, geologia, hidrogeologia, meteorologia, topografia ; compactação das células, impermeabilização e cabertura vegetal (GADOTTH, 1997).

A produção é freqüentemente observada: dentro de poucos meses após o início da operação do aterro, quando a capacidade de campo do aterro é excedida e o resíduo fica saturado com água 0 grau de saturação dependerá da presença ou ausêncią de cobertura, tipo de material de cobertura, composição do lixo, grau de compactação, condições climáticas e conteúdo inicial de água presente no resíduo (CLARETO et al., 1997).

\subsection{POLUIÇÃO E CONTAMINAÇÃO.dO SOLO E DA ÁGUA SUBTERRÂNEA}

Os resíduos sólidos podem poluir e contaminar os recursos naturais.

Os termos contaminação. e poluição são utilizados regularmente como șinônimos. Este fato pode ser justificicado pela origem dessas palavras, que significąm a mesma coisa. BRANCO (1991) analisou a origem e significado dessas palavras e cita 
que poluição deriva do latim polluere que significa manchar, sujar e a palavra contaminação, do latim significa:misturar, infectar, sujar e manchar.

BRANCO (1991) distingue os termos da seguinte forma: contaminação refere-se à simples transmissão pela água de: elementos compostos ou microorganismos que possam prejudicar a saúde do homem ou de animais que a utilizam, sendo um veículo

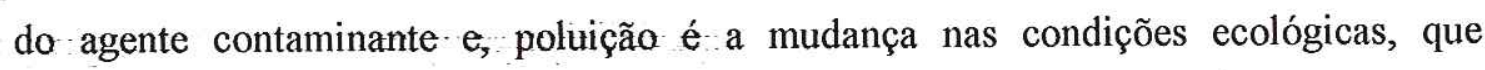
produzem. transformações no ambiente, de modo a torná-lo impróprio ao desenvolvimento de populações. $O$ autor ainda cita que o conceito de contaminação está associado ao de poluição, ou que constitui um aspecto particular deste.

FREEZE e CHERRY (1979) sugerem definições mais simples, porém com a mesma essência das definições acima. Para estes autores todos os solutos introduzidos no sistema hidrológico, como resultado das atividades do homem, são contaminantes e, quando a concentração destes atingem níveis ameaçadores, o termo contaminate é substituído por poluente.

Da mesma forma, de acordo com CETESB (2003a) "contaminação é a introdução no meio ambiente de organismos patogênicos, substâncias tóxicas ou outros elementos, em concentraçães que possam afetar a saúde humana. É um caso particular de połuição".

Observa-se que os conceitos são confundidos, mas é possível definí-los separadamente. Contaminação é a transmissão pela água de elementos, compostos ou microorganismos que podem prejudicar a saúde do homem ou de animais que a bebem. Neste caso a água desempenha um papel de veículo do agente contaminante, e não de ambiente ecológico alterado. Poluição se caracteriza por seus efeitos ecológicos oriundos de transformações do meio ambiente, de forma que este se tornaria impróprio para o desenvolvimento das populações.

Normalmente, contaminação e poluição estão associadas porque podem ter a mesma origem: a introdução de resíduos estranhos à natureza do ambiente. Estes resíduos são comumente de natureza complexa e contêm substâncias que prejudicam ecologicamente o meio e, ao mesmo tempo, elementos nocivos à saúde do homem e dos animais terrestres (PASCHOALATO, 2000).

Os principais contaminantes da água subterrânea são metais pesados, substâncias organo-químicas, elementos radioativos, fertilizantes, pesticidas e microorganismos segundo LEITE (1997). 
Os contaminantes do solo são classificados com relação à sua origem: urbanos (líquidos de aterros sanitários; resíduos sólidos entre outros); industriais (produtos químicos tóxicos) e agrícolas (pesticidas, produtos fitossanitários entre outros). Os contaminantes do solo também podem ser classificados em relação às suas características física (radioatividade), química (solventes) e bacteriológica (bactérias, vírus) segundo LEITE (1997).

\subsection{ASPECTOS GEOLÓGICOS A SEREM CONSIDERADOS NA LOCALIZAÇÃO DE ATERROS SANITÁRIOS}

A proteção do meia ambiente em que um aterro está localizado, contra conseqüências adversas da disposição de resíduos, é um problema da atualidade que envolve questões de geologia para análise da migração dos contaminantes, a partir dos locais onde são dispostos e também da engenharia, de forma a garantir estabilidade dos locais usados para a disposięão (FREITAS, 1996).

Sob o aspecto geológico, o local para a disposição final de resíduos não deve conter fraturas ou estruturas que permitam a infiltração do chorume na água subterrânea, pois as condições geológicas e hidrogeológicas podem propiciar a migração de contaminantes. Desta forma; sondagens geofísicas, método raio gama, eletrorresistividade, polarização induzida, magnetometria, entre outros métodos podem ajudar na escolha do local e no monitoramento da água subterrânea (NASCIMENTO, 2001).

Ainda hoje, os aterros são projetados e monitorados de forma imprópria para a proteção da água subterrânea, pelo conhecimento incompleto do tempo de residência do chorume nas camadas compactadas, da integridade de liners $^{3}$, da heterogeneidade dos aqüíferos, além das trajetórias dos contaminantes (FREITAS, 1996).

Segundo as normas de projeto e execução de aterros sanitários, estes devem dispor de sistemas de impermeabilização de base (liners) para minimizar a migração de contaminantes presentes no chorume, de forma que não atinjam o solo de fundação e, conseqüentemente, possíveis aquíferos existentes. Para construção dos liners podem ser utilizados diversos materiais, de formas diferentes e dentre os tipos de liners mais

\footnotetext{
${ }^{3}$ Liners são barreiras protetoras colocadas sobre o fundo e as paredes de aterros e lagoas e que devem reter o máximo a percolação de flứdos contaminantes para o meio físico, também denominadas de menbrana para impermeabilização de base.
} 
comuns, destacam-se os depósitos naturais de solos de baixa permeabilidade, os de argila compactada e os geossintéticos (CHRISTENSEN et al., 2001).

O impacto de um aterro na qualidade da água subterrânea depende de inúmeros fatores, dentre os quais, a natureza da barreira que pretende limitar e controlar a migração de contaminantes é o mais importante. Barreiras de solo, contendo argilominerais em quantidade suficiente para produzir baixa permeabilidade, são utilizadas para evitar a rápida migração de percolados dos aterros (CHRISTENSEN et al., 2001).

A argila pode atuar, também, como importante meio para a atenuação de alguns dos constituintes químicos do chorume, devido a processos como adsorção, precipitação e biodegradação, sendo que a mais importante função dos liners argilosos é a capacidade de atenuação dos contaminantes a longo prazo (THORNTON et al., 2000).

Emprega-se liners sintéticos (solo/geomembrana) para impermeabilização das bases dos aterros sanitários, constituídos por geomembrana intercalada nas camadas de argila compactada (LEITE, 1997). No entanto, nenhum material utilizado nos sistemas de impermeabilização de base é totalmente impermeável aos constituintes químicos do chorume e, alguns deles poderão migrar através. da barreira por adveç̧ão ou difusão (TONNAER, 1998).

Em projetos de aterros sanitários é necessário estimar o transporte advectivo e/ou difusivo através do liner, de forma que a quantidade de contaminantes liberada dos aterros seja mínima e os impactos no ambiente desprezíveis. GUIGUER (1987) ${ }^{4}$ apud ANTONIALLI (2002) constatou a migração longitudinal da pluma de contaminante por 200 metros, decorridos 5 anos de instalação do aterro de Taubaté/SP, em área de aqǘfero livre, constituído por sedimentos argilo-arenosos da Formação Caçapava.

Outro estudo realizado por NASCIMENTO (2001) constatou a poluição do solo, das águas superfíciais e subterrâneas provocada pelo chorume no aterro sanitário de São João; localizado no município de São Paulo (SP), o qual opera desde 1992. O aterro passou por um processo de seleção de áreas, porém sua operação não foi eficaz de acordo com os resultados de monitoramento das águas.

CHRISTENSEN et al. (1992) afirmam que os contaminantes que infiltram no solo com a água são influenciados por processos que determinam suas taxas de acumulação, deslocamento e degradação. Dentre eles, o processo de adsorção é

\footnotetext{
${ }^{4}$ GUIGUER, J.N. Poluiçãa das águas subterrâneas por aterros sanitários: uma abordagem matemático exponenciat: (1987). 109p. Bissertação (Mestrado). Escola Politécniça. São Paulo.
} 
dominante no retardo do movimento destes materiais, mas cada tipo difere em seu estilo de adsorção. No caso de metais pesados, a mobilidade e a capacidade de adsorção vão depender do $\mathrm{pH}$, do conteúdo e tipos de argilas, entre outros.

A infiltração de percolado, geralmente, ocorre na forma de pluma, com migração descendente na direção da água subterrânea (IPT, 1995). Ainda segundo o IPT (1995), dentre os principais grupos de contaminantes ou poluentes e seus indicadores destacamse os cloretos, nitratos e metais pesados por indicarem fontes de contaminação.

A percolação e transporte de contaminantes ocorre, preferencialmente, em solos com estruturas da rocha matriz preservadas (TRESSOLDI, 1991). Na zona não saturada do solo, onde os poros são preenchidos por ar e água, o fluxo de água é dependente da força de gravidade e da forma dos poros, sendo vertical para baixo. Na zona saturada, os poros são preenchidos por água, o fluxo é dependente do gradiente hidráulico e os contaminantes podem se espalhar por grandes áreas e longas distâncias, após um certo período de tempo variável.

A presença de macroporos, cavidades e canalículos são fatores importantes para o aumento da velocidade de infiltração das águas e dos contaminantes que percolam na zona não saturada dos materiais não consolidados. Caracterizam-se, assim, as plumas de contaminação com concentrações variáveis no espaço e no tempo, dependendo das condições hidrogeológicas locais (TRESSOLDI, 1991).

Vários testes realizados durante a percolação de chorume em áreas de disposição finat de resíduos sólidos, mostram que as seguintes reações podem ocorrer no solo em contato com esses líquidos, segundo a experiência de BRANDL (1992): Troca de cátions e ânions; Adsorção (cátions e ânions); Quimiosorção e mundanças graduais entre adsorção e quimiosorção; Troca de prótons; Alteração das forças elétricas da superficie dos minerais de argila; Alteração do patencial do sistema; Neutralização dos ácidos e bases; Deslocamento das bases fracas ou ácidos fracos por compostos (ácidos ou básicos) mais fortes; Lixiviação/erosão do cimento dos poros; Dissolução/desintegração dos minerais de argila e nova formação de fluídos ligantes (precipitação de metais amorfos); Desenvolvimento de compostos gelatinosos e cristais; Cimentação, formação de concreções, solidificação, endurecimento e processos de aumento de resistência do solo; Alterações das propriedades de umidade da superfície dos grãos; Alteração na concentração iônica da água dos interstícios dos poros; Alteração das tensões capilares; Desenvolvimento de moléculas dipolares de água na superfície dos grãos de argila. 
O QUADRO 1 resume os principais processos físicos, químicos e biológicos que controlam a migração de contaminantes.

QUADRO 1 - Processos físicos, químicos e biológicos que controlam a migração de contaminantes

\begin{tabular}{|c|c|c|}
\hline $\begin{array}{l}\text { PROCESSOS } \\
\text { FÍSICOS }\end{array}$ & DESCRIÇÃO & EFEITOS \\
\hline Fluxo Subterrâneo & $\begin{array}{l}\text { A água subterrânea flui através dos poros } \\
\text { e fraturas, em solos e rochas. }\end{array}$ & $\begin{array}{l}\text { Transporta contaminantes } \\
\text { dissolvidos ou em solução. }\end{array}$ \\
\hline $\begin{array}{l}\text { Dispersão } \\
\text { Hidrodinâmica }\end{array}$ & $\begin{array}{l}\text { A água subterrânea flui mais rapidamente } \\
\text { em alguns poros e fraturas que em outros. } \\
\text { Há mistura de águas contaminadas e não } \\
\text { contaminadas. }\end{array}$ & $\begin{array}{l}\text { Reduz a concentração, mas } \\
\text { aumenta a área atingida pelos } \\
\text { contaminantes. }\end{array}$ \\
\hline Separação Gravimétrica & $\begin{array}{l}\text { Líquidos menos densos que a água tendem } \\
\text { a flutuar no topo dos aquíferos e os mais } \\
\text { densos tocalizam-se nas porções basais } \\
\text { destes. }\end{array}$ & $\begin{array}{l}\text { Depende da densidade do } \\
\text { contaminante, pode criar zonas de } \\
\text { concentração no topo ou na base } \\
\text { dos aqüíferos. }\end{array}$ \\
\hline Filtração & $\begin{array}{l}\text { Solos e rochas podem filtrar partículas em } \\
\text { suspensão nạ água subterrânea. }\end{array}$ & $\begin{array}{l}\text { Reduz a concentração dos } \\
\text { contaminantes em suspensão. }\end{array}$ \\
\hline Decaimento 1 & $\begin{array}{l}\text { Rearranjo na estrutura atômica, com a } \\
\text { formação de elemento mais estável e } \\
\text { emissão de energia. }\end{array}$ & $\begin{array}{l}\text { Reduz a concentração dos } \\
\text { contaminantes radioativos, } \\
\text { segundo taxas previsíveis, com } \\
\text { emissão de radioatividade. }\end{array}$ \\
\hline Volatili & $\begin{array}{l}\text { Contaminantes voláteis evaporam do } \\
\text { lençol freático para a zona não saturada ou } \\
\text { para a atmosfera. }\end{array}$ & $\begin{array}{l}\text { Reduz a concentração dos } \\
\text { contaminantes voláteis. }\end{array}$ \\
\hline Variação Térmica & Contaminantes com temperatura elevada. & $\begin{array}{l}\text { O calor dos contaminantes afeta } \\
\text { as propriedades físicas da água e } \\
\text { as propriedades químicas dos } \\
\text { resíduos. }\end{array}$ \\
\hline $\begin{array}{l}\text { PROR } \\
\text { QUÍl }\end{array}$ & DESCRIÇÃO & EFEITOS \\
\hline Adsarção e Troca Iônica & $\begin{array}{l}\text { Alguns contaminantes dissolvidos tendem } \\
\text { a aderir às superfícies dos minerais. }\end{array}$ & $\begin{array}{l}\text { Reduz a concentração e e/ou a } \\
\text { velocidade de migração. }\end{array}$ \\
\hline Reação de Oxi-redução & $\begin{array}{l}\text { Alterą̧ões da estrutura molecular e } \\
\text { propriedades iônicas dos confaminantes. }\end{array}$ & $\begin{array}{l}\text { Pode alterar a toxicidade, } \\
\text { comportamento químico } \\
\text { mobilidade dos contaminantes. }\end{array}$ \\
\hline Hidrólise & $\begin{array}{l}\text { Reações com água, que alteram a natureza } \\
\text { iônica e malecular dos contaminantes. }\end{array}$ & $\begin{array}{l}\text { Reduz a concentração dos } \\
\text { contaminantes. }\end{array}$ \\
\hline Complexação & $\begin{array}{l}\text { Contaminantes dissolvidos associam-se a } \\
\text { outros compostos para formar novos } \\
\text { produtos. }\end{array}$ & $\begin{array}{l}\text { Pode aumentar a mobilidade dos } \\
\text { contaminantes e alterar o } \\
\text { comportamento químico. }\end{array}$ \\
\hline $\begin{array}{l}\text { PROCE } \\
\text { BIOLÓG }\end{array}$ & DESCRIÇÃOO & EFEITOS \\
\hline $\begin{array}{l}\text { Transformação } \\
\text { Microbioquímica }\end{array}$ & $\begin{array}{l}\text { Bactérias e outros microorganismos } \\
\text { alteram ou decompõem contaminantes } \\
\text { orgânicos e alguns inorgânicos por reações } \\
\text { enzimáticas e respiração. }\end{array}$ & $\begin{array}{l}\text { Reduz a concentração de alguns } \\
\text { contaminantes, originando } \\
\text { produtos tóxicos. }\end{array}$ \\
\hline
\end{tabular}

Fonte:TRESSOLDI, 2002 


\subsection{FORMAÇÃO DO SOLO}

A palavra "solo" pode ter diversas conotações, dependendo da finalidade para qual se estuda. Por milhares de anos o homem olhou para o solo como sistema utilitário, mas essa situação mudou há 10000 anos quando este descobriu a agricultura e mais tarde o percebeu como material de construção. Até então, pouco ou nada se refletia sobre a origem e natureza do solo.

Pode-se dizer que tudo começou na China, que fez a mais antiga classificação dos solos para diferentes culturas e, mais tarde outras civilizações, como egípcia, grega e romana, também reconheceram a existência de diversos tipos de solos, possuindo atributos específicos não só para a produção agrícola, mas também para a construção civil (GUSMÃO FILHO, 2002).

A partir do século XIX, com a acumulação de conhecimentos, houve a necessidade de definir mais concretamente o solo, pois o homem passou a tirar sustento dele. Assim, outras questões começaram a surgir, como a proteção e a conservação dos solos, ecossistemas e aqüíferos; a construção de vias de transporte com cortes e aterros, de barragens, açudes e outras edificações; a exploração de minas, a irrigação e o lançamento de fundações. A engenharia passou a considerar o solo como sustento de suas obras (GUSMÃO FILHO, 2002).

Solo é a superfície inconsolidada que recobre as rochas, formado por um conjunto de corpos tridimensionais, resultante da ação integrada do clima e organismos sobre o material de origem, condicionado pelo relevo em diferentes períodos de tempo, o qual representa características que constituem a expressão dos processos e dos mecanismos dominantes de sua formação (RAIJ, 1991).

Os solos formam-se na natureza em conseqüência de cinco fatores: material de origem, clima, relevo, tempo e organismos (RAIJ, 1991).

O material de origem ou rocha matriz é o de maior importância na formação dos solos, sendo que a sua composição inicial irá condicionar a textura, a constituição mineralógica e a riqueza em nutrientes, definindo as características dos solos. Um material de origem desprovido de nutrientes, como velhas rochas sedimentares, empobrecidas pelo intenso intemperismo e processos geológicos desgastantes dão origem a solos pobres em nutrientes (GUERRA e CUNHA, 2003).

Durante o processo de formação do solo ocorre a destruição de minerais sob a ação do intemperismo. O intemperismo é um conjunto de processos físicos, químicos e 
biológicos que levam à desagregação química dos minerais das rochas devido ao efeito das condições atmosféricas. Esses processos atuam no material de origem do solo constantemente, promovendo reações que transformam a estrutura original dos minerais menos resistentes, levam à remoção de elementos químicos e à formação de novos minerais (GUERRA e CUNHA, 2003).

O intemperismo físico ocorre por variações na temperatura, calor, congelamento da água em fissuras, ação mecânica do vento e da água, levando à desagregação das rochas, sem afetar sua composição química. Já o intemperismo químico que altera a composição dos minerais das rochas, de acordo com a reação envolvida e pode ser de vários tipos. Ou seja, como a água é o agente principal das reações (auxiliado pelo oxigênio e o gás carbônico dissolvidos nela e também por ácidos orgânicos provenientes da decomposição de restos de seres vivos), a ação pode se dar por solubilização simples de compostos, por hidrólise (adição de $\mathrm{OH}^{-}$), hidratação (incorporação de $\mathrm{H}_{2} \mathrm{O}$ ), oxidação (perda de elétrons), redução (ganho de elétrons) ou carbonatação (VIEIRA, 1975).

Nos processos intempéricos a perda de sílica solúvel e de cátions básicos no material de origem é comum, como sódio $(\mathrm{Na})$, cálcio $(\mathrm{Ca})$, potássio $(\mathrm{K})$ e magnésio $(\mathrm{Mg})$ e, elementos como ferro (Fe), alumínio (Al), titânio (Ti) e manganês (Mn) sofrem uma concentração relativa (RAIJ, 1991).

Portanto, mostra-se relevante sabermos a composição do material de origem para identificar quais elementos são de ocorrência natural no solo ou não, facilitando a identificação de possíveis fontes de contaminação.

\subsubsection{SOLO COMO ATENUADOR NATURAL}

O reconhecimento de que a qualidade do solo pode também significar um problema de saúde pública e representar riscos para o ecossistema é recente. O caráter acumulativo e a baixa mobilidade dos poluentes são características principais da poluição do solo. Esse termo "połuição do solo" refere-se à presença de substâncias que alteram negativamente sua qualidade e podem afetar a vegetação, a qualidade da água subterrânea ou, ainda, representar risco para a saúde das pessoas que entrarem em contato direto com ele, já que a migração dos poluentes através do solo para as águas 
superficiais e subterrâneas é uma ameaça para a qualidade dos recursos hídricos (SANCHEZ, 2001).

A disposição de resíduos sólidos urbanos e industriais em locais inadequados pode promover a poluição do solo, muitos metais (como $\mathrm{Cd}, \mathrm{Cu}, \mathrm{Pb}, \mathrm{Sn}$ e $\mathrm{Zn}$ ) podem se dispersar no solo, nas águas subterrâneas e superficiais devido ao percolado. (SANCHEZ, 2001).

YONG et al: (1992) dissertam sobre a capacidade de sorção do solo em relação a vários tipos de solutos contaminantes, analisando a capacidade do solo como "tampão", ou seja, a capacidade de retenção de metais pesados e de sorção de constituintes. Através de experimentos em soluções ácidas, esses autores analisaram a capacidade de tamponamento de diversos argilo-minerais puros em comparação com o solo natural, mas infelizmente não especificaram o tipo de solo e elucidaram a grande capacidade de tamponamento da caulinita.

A atenuação do movimento de contaminantes no solo é de grande importância na proteção das áreas de disposição de resíduos, onde a maior ou menor capacidade do solo como atenuante ditará as regras dos processos construtivos dos selos de proteção destes locais.

\subsection{METAIS PESADOS NO SQLO}

O solo é um compartimento natural constituído por componentes minerais e orgânicos, com suas propriedades físicas, químicas e biológicas. A composição dos solos é extremamente diversa e governada por muitos fatores, sendo os mais importantes, as condições climáticas e o material de origem, ou seja, a rocha matriz (VIEIRA, 1975).

As substâncias naturalmente ausentes no solo são aquelas geradas antropogenicamente em processos industriais, onde a maior parte dos problemas ambientais causados pelos compostos gerados nesses processos é originada na destinação inadequada no solo de resíduos industriais e domésticos e por práticas agrícolas indiscriminadas. Já as substâncias naturalmente presentes no solo são as substâncias inorgânicạs de interesse ambiental (metais pesados) que ocorrem naturalmente no solo. Os valores de referência do padrão de qualidade do solo podem 
ser estabelecidos em função das suas concentrações naturais dos metais, considerando a variação das propriedades do solo (CETESB, 2001).

Alguns dos contaminantes presentes no solo, que geralmente apresentam-se de forma natural devido às características da rocha matriz e/ou também oriundos de fontes antropogênicas, são os metais pesados. Estes são elementos com peso específico maior que $6 \mathrm{~g} . \mathrm{cm}^{-3}$ ou que possuem um número atômico maior que 20 (ALLOWAY,1995).

A expressão "metais pesados" engloba metais, semi-metais e mesmo não metais (como o Selênio - Se), tratando-se de um conjunto heterogêneo de elementos. Entretanto, pode-se definir como qualquer elemento (metal, semimetal ou não metal) que esteja associado a problemas de poluição, utilizado genericamente para os elementos químicos que contaminam o meio ambiente, e podem provocar diferentes níveis de dano à biota (ALLOWAY, 1995).

Os seguintes elementos podem ser incluídos nesse grupo: Antimônio ( $\mathrm{Sb}$ ), Arsênio (As), Bário (Ba), Berílio (Be), Bismuto (Bi), Boro (B), Cádmio (Cd), Chumbo $(\mathrm{Pb})$, Cobalto $(\mathrm{Co})$, Cobre $(\mathrm{Cu})$, Cromo (Cr), Escândio ( $\mathrm{Sc})$, Estanho (Sn), Estrôncio (Sr), Ferro (Fe), Gálio (Ga), Ítrio (Y), Lantânio (La), Lítio (Li), Manganês (Mn), Mercúrio (Hg), Molibdênio (Mo), Níquel (Ni), Prata (Ag), Tecnécio (Tc), Titânio (Ti), Vanádio (V), Zinco (Zn) e Zircônio.(Zr).

Os elementos $\mathrm{As}, \mathrm{Co}, \mathrm{Cr}, \mathrm{Cu}$, Se e $\mathrm{Zn}$ são essenciais aos organismos vivos e os que se apresentam com maior freqüência no solo são: $\mathrm{Cu}, \mathrm{Fe}, \mathrm{Mn}, \mathrm{Mo}, \mathrm{Zn}, \mathrm{Co}, \mathrm{Ni}, \mathrm{V}$, Alumínio (Al), Ag, Cd, Cr, Hg e Pb (MALAVOLTA, 1994).

Os teores de metais pesados solúveis no solo são geralmente baixos. Entretanto, o emprego de fungicidas, fertilizantes minerais e esterco de animais na agricultura, bem como o descarte de resíduos urbanos; domiciliares e industriais, podem elevar a concentração de metais pesados no solo a níveis capazes de causar danos à toda cadeia alimentar (ALLOWAY, 1995).

Das fontes potenciais de contaminação do solo, os resíduos urbanos e industriais apresentam grande variação nos teores de metais pesados, os quais estão intimamente relacionados à atividade econômica regional. Segundo MALAVOLTA (1994), os metais no solo são derivados do intemperismo, que age sobre a rocha matriz e também de fontes externas naturais (erup̨̣ão vulcânica) ou antrópicas (indústrias, agricultura). As maiores fontes de emissão de metais para o ambiente estão listados no QUADRO 2. 
QUADRO 2 - Principais fontes antropogênicas de emissão de metais pesados

\begin{tabular}{|c|c|}
\hline FONTE & $\begin{array}{l}\text { PRINCIPAIS METAIS } \\
\text { LANÇADOS }\end{array}$ \\
\hline Produção de metais não ferrosos & Todos \\
\hline Galvanoplastia & $\mathrm{Cu}, \mathrm{Cd}, \mathrm{Zn}, \mathrm{Cr}, \mathrm{Ni}$ \\
\hline Fabricação de baterias & $\mathrm{Cd}, \mathrm{Pb}, \mathrm{Hg}$ \\
\hline Fabricação de haletos de chumbo & $\mathrm{Pb}$ \\
\hline Emissão de veículos motores & $\mathrm{Pb}$ \\
\hline $\begin{array}{l}\text { Empregos menores do mercúrio (odontológico, } \\
\text { tintas a base de antraquinona) }\end{array}$ & $\mathrm{Hg}$ \\
\hline Processo de curtimento de couro & $\mathrm{Cr}$ \\
\hline $\begin{array}{l}\text { Destruição (por queima) da madeira tratada com } \\
\text { conservantes }\end{array}$ & As \\
\hline Desgaste de pneus & $\mathrm{Zn}$ \\
\hline Processos fotográficos & $\mathrm{Cd}, \mathrm{Cr}$ \\
\hline Produção de ferro e aço & Todos \\
\hline Fabricação de fertilizantes fosfatados & Todos \\
\hline Manufatura de cimento & $\mathrm{Cd}, \mathrm{Pb}, \mathrm{Hg}$ \\
\hline Atividades Agrícolas (Fertilizantes e Herbicidas) & $\mathrm{Cd}, \mathrm{Hg}, \mathrm{Cu}, \mathrm{Zn}$ \\
\hline Depósito de lixo (Aterro e Incineração) & Todos \\
\hline $\begin{array}{l}\text { Descarga de bota-fora de dragagens em águas } \\
\text { costeiras }\end{array}$ & Todos \\
\hline Descarga de resíduos de carvão & Todos \\
\hline $\begin{array}{l}\text { Depósito de esgoto e águas servidas que recebem } \\
\text { contribuição de muitas fontes acima }\end{array}$ & Todos \\
\hline Intemperismo natural e drenagem de minas & Todos \\
\hline Sistemas de encanamento doméstico & $\mathrm{Zn}, \mathrm{Pb}, \mathrm{Cu}$ \\
\hline
\end{tabular}

FONTE: BOFF, 1999 (modificado)

O critério para estabelecer a concentração natural de metais é a correlação de sua concentração com algumas propriedades físicas e químicas do solo, de forma que estas influenciam as condições micro-ambientais e são determinantes da adsorção de metais com a matéria orgânica e a porcentagem da fração argila (ALLOWAY, 1995). A 
presença de alguns metais é característico em determinados tipos de solo, como pode ser observado no QUADRO 3 a seguir.

QUADRO 3 - Minerais primários e respectivos elementos metálicos pesados que o solo pode fornecer

\begin{tabular}{cc}
\hline Mineral Primário & Metais \\
Olivina & $\mathrm{Fe}, \mathrm{Si}, \mathrm{Ni}, \mathrm{Co}, \mathrm{Mn}, \mathrm{Li}, \mathrm{Zn}, \mathrm{Cu}, \mathrm{Mo}$ \\
Hornblenda & $\mathrm{Fe}, \mathrm{Al}, \mathrm{Si}, \mathrm{Ni}, \mathrm{Co}, \mathrm{Mn}, \mathrm{Se}, \mathrm{Li}, \mathrm{Zn}, \mathrm{Cu}, \mathrm{Ga}, \mathrm{V}$ \\
Augita & $\mathrm{Al}, \mathrm{Si}, \mathrm{Ni}, \mathrm{Co}, \mathrm{Mn}, \mathrm{Se}, \mathrm{Li}, \mathrm{V}, \mathrm{Zn}, \mathrm{Pb}, \mathrm{Cu}, \mathrm{Ga}$ \\
Biotita & $\mathrm{Fe}, \mathrm{Al}, \mathrm{Si}, \mathrm{Rb}, \mathrm{Ba}, \mathrm{Ni}, \mathrm{Co}, \mathrm{Se}, \mathrm{Li}, \mathrm{Mn}, \mathrm{V}, \mathrm{Zn}$, \\
& $\mathrm{Cu}, \mathrm{Ga}$ \\
Apatita & $\mathrm{Pb}, \mathrm{Sr}$ \\
Anortita & $\mathrm{Al}, \mathrm{Si}, \mathrm{Sr}, \mathrm{Cu}, \mathrm{Ga}, \mathrm{Mn}$ \\
Andesina & $\mathrm{Al}, \mathrm{Si}, \mathrm{Sr}, \mathrm{Cu}, \mathrm{Ga}, \mathrm{Mn}$ \\
Oligoclásio & $\mathrm{Al}, \mathrm{Si}, \mathrm{Cu}, \mathrm{Ga}$ \\
Albita & $\mathrm{Al}, \mathrm{Si}, \mathrm{Cu}, \mathrm{Ga}$ \\
Ortoclásio & $\mathrm{Al}, \mathrm{Si}, \mathrm{Rb}, \mathrm{Ba}, \mathrm{Sr}, \mathrm{Cu}, \mathrm{Ga}$ \\
Moscovita & $\mathrm{Fe}, \mathrm{Ti}, \mathrm{Rb}, \mathrm{Ba}, \mathrm{Sr}, \mathrm{Ga}, \mathrm{V}$ \\
Ilmenita & $\mathrm{Fe}, \mathrm{Ti}, \mathrm{Co}, \mathrm{Ni}, \mathrm{Cr}, \mathrm{V}$ \\
Magnesita & $\mathrm{Fe}, \mathrm{Zn}, \mathrm{Co}, \mathrm{Ni}, \mathrm{Cr}, \mathrm{V}$ \\
Turmalina & $\mathrm{Fe}, \mathrm{B}, \mathrm{Al}, \mathrm{Si}, \mathrm{Li}, \mathrm{F}, \mathrm{Ga}$ \\
\hline
\end{tabular}

Fonte: GUERRA e CUNHA, 2003

Os metais estão presentes naturalmente nos solos, em concentrações variáveis de acordo com a sua gênese. As concentrações atuais encontradas nos solos são baixas devido à formação de complexos altamente estáveis destes elementos com ácidos húmicos ou a formação de óxidos e hidróxidos, o que reduz sua solubilidade no solo. No entanto, estas concentrações podem sofrer incremento devido a processos antrópicos, principalmente por fontes difusas. A maioria das informações disponíveis na literatura brasileira refere-se à fertilidade do solo e poucas referem-se à questão ambiental (ALLOWAY,1995).

Segundo MATIAZZO e ANDRADE (2000), trabalhos sobre comportamento de metais pesados em solos, sua fitodisponibilidade, com conseqüente passagem para a cadeia alimentar, é objeto de estudo na literatura mundial. Entretanto, no Brasil, esses estudos restringem-se a fornecer dados sobre $\mathrm{Cu}$ e $\mathrm{Zn}$, tendo em vista as limitações dos métodos analíticos utilizados para detectar concentrações traços de $\mathrm{Cd}, \mathrm{Hg}$ e $\mathrm{Pb}$ (MALAVOLTA, 1994).

A possibilidade de contaminação das plantas e do lençol freático pela disposição ineorreta de resíduos sólidos domiciliares e industriais contendo metais pesados é uma 
das principais preocupações atuais. Os metais pesados podem provocar graves problemas para a saúde das pessoas que os consomem durante período prolongado ou em quantidades elevadas, pois são acumulativos (MATTIAZZO e ANDRADE, 2000).

Os metais são elementos altamente tóxicos aos seres vivos e têm recebido considerável atenção com respeito a acumulação no solo, assimilação pelas plantas e contaminação das águas subterrâneas (YONG et al., 1992).

A maior parte dos metais estão sob a forma de sais, óxido ou hidróxidos. Mas alguns metais $(\mathrm{Pb}$ e $\mathrm{Hg})$ podem estar presentes na forma orgânica. As espécies orgânicas tendem a ser mais tóxicas que as inorgânicas e para as espécies inorgânicas serem tóxicas precisam estar disponíveis na forma dissolvida. Diante deste fato, reforçase a necessidade de constante monitoramento e intensa investigação sobre a complexação e precipitação de metais pesados no solo, visando minimizar a sua movimentação através do perfil do solo (CHRISTENSEN et al., 2001).

\subsubsection{COMPORTAMENTO DOS METAIS PESADOS NOS SOLOS}

O comportamento químico dos metais no solo é bastante complexo e influenciado por diferentes tipos de reações, tais como adsorção, complexação, precipitação, oxidação e redução, que definem a biodisponibilidade desses elementos para as plantas. A solubilidade e lixiviação definem a disponibilidade desses elementos nos solos e, conseqüentemente, o seu potencial de risco para a saúde humana e para o meio ambiente (LANGE et al., 2001). A disponibilidade dos metais pesados no solo representa uma condição, na qual os elementos químicos sofrem interferência de fatores relacionados aos atributos do solo, à natureza dos elementos, à presença de outros elementos, às suas interações e à natureza dos resíduos orgânicos dispostos no solo (ALLOWAY, 1995).

Em relação ao solo, as propriedades como $\mathrm{pH}$, potencial redox, capacidade de troca de cátions (CTC), teor de matéria orgânica e seu estágio de decomposição, teor de óxidos de ferro, alumínio e manganês, características dos minerais de argila, além de propriedades físicas como porcentagem de areia, silte e argila (que definem textura do solo), atividade biológica e fatores ambientais, são as variáveis que devem ser consideradas em relação à dinâmica e disponibilidade dos metais no perfil do solo (OLIVEIRA et al., 2001). 
Em locais de disposição de resíduos sólidos urbanos sobre o solo, existem mecanismos referentes à capacidade de assimilação de metais pesados, que envolvem a combinação de: mobilização por lixiviação (particularmente em condições ácidas); precipitação de metais por sulfeto, carbonato ou hidróxido; imobilização aumentada por condições redutoras, juntamente com a filtração e sorção durante a recirculação de percolado; mobilização e remobilização pela complexação com substâncias húmicas (ROSS, 1990).

$\mathrm{O} \mathrm{pH}$ é a propriedade do solo que interfere de forma mais intensa na disponibilidade dos metais (exceto para $\mathrm{As}, \mathrm{Mo}, \mathrm{Se}$, e alguns estados de valência do $\mathrm{Cr}$ ), já que afeta a capacidade de complexação de metais em água, determinando quando um metal está precipitado ou dissolvido. Os metais pesados têm suas disponibilidades reduzidas quando ocorre a elevação do $\mathrm{pH}$, em decorrência da formação de precipitados, do aumento da intensidade de adsorção aos colóides do solo e por conferir maior estabilidade aos complexos que se formam entre os metais e a fração húmica dos solos (ALLOWAY, 1995).

Em solos ácidos ( $\mathrm{pH} 4,2$ a 6,6) Cd, $\mathrm{Hg}$, Ni e $\mathrm{Zn}$ apresentam relativa solubilidade, e para os elementos As, $\mathrm{Be}$ e $\mathrm{Cr}$ apresentam solubilidade mais restrita. Nessa mesma condição, $\mathrm{Cu}, \mathrm{Pb}$ e Se têm solubilidades sensivelmente reduzidas. Quando se trata de solos neutros ou com certa alcalinidade $(\mathrm{pH} \mathrm{6,7} \mathrm{a} \mathrm{7,8),} \mathrm{As} \mathrm{e} \mathrm{Cr}$ são de relativa solubilidade; $\mathrm{Be}, \mathrm{Cd}, \mathrm{Hg}$ e $\mathrm{Zn}$ são de solubilidade limitada e $\mathrm{Cu}, \mathrm{Pb}$ e $\mathrm{Ni}$ são praticamente insolúveis (MENEZES, 1995).

O potencial redox de um solo interfere na valência dos metais, nas formas químicas que podem originar e, também no $\mathrm{pH}$ do solo. Assim, em função da forma de ocorrência do metal e do pH do meio, podem existir condições mais ou menos favoráveis à disponibilidade dos metais. Normalmente, quando predominam condições redutoras no solo, queda no nível de oxigênio e de íons $\mathrm{H}^{+}$livres, têm-se uma diminuição do potencial redox, resultando em aumento no $\mathrm{pH}$. Esse fenômeno contribui para que haja redução da disponibilidade de metais, na medida em que originam formas menos solúveis desses elementos (ALLOWAY, 1995).

A capacidade de troca de cátions de um solo refere-se à quantidade de cargas negativas presentes nas superfícies das suas frações coloidais. Tais cargas, de acordo com suas quantidades e características intrínsecas, conferem variação na capacidade do solo de adsorver cátions (ALLOWAY, 1995). 
OLIVEIRA et al. (2001) observaram que os efeitos prejudiciais da presença de metais, provenientes da destinação final de resíduos sólidos, manifestaram-se em solos com baixa capacidade de troca catiônica ( CTC menor que 5 meq/100g de solo) e baixos conteúdos de argila, particularmente quando o $\mathrm{pH}$ do solo (determinado em água) estava em torno de 4,0. No entanto, segundo estes mesmos autores, os parâmetros mais indicados para definir a quantidade máxima de metais permitida em um solo sem causar danos, estejam eles presentes num resíduo orgânico ou inorgânico, são o conteúdo de argita e de óxidos de ferro e alumínio.

Os minerais de argila, a matéria orgânica, os óxidos e hidróxidos são as frações que, de acordo com suas naturezas e níveis de ocorrência, definem a CTC do solo. Quando se trata de solos intemperizados, a matéria orgânica, os óxidos e hidróxidos, assumem grande importância e passam ser a maior fonte de cargas negativas superficiais, definindo a capacidade de adsorção do solo (ALLOWAY, 1995).

Segundo MATOS (1995), os solos podem apresentar uma grande variedade de sítios de adsorção, com diferentes propriedades de ligações e grande quantidade de complexos aquoso-iônicos e não iônicos capazes de participarem da adsorção e, possivelmente, dos processos de precipitação de metais.

A matéria orgânica e os óxidos do solo apresentam sistemas de aprisionamento de metais. Entre esses sistemas, pode-se citar a formação de quelatos complexos, que são formados da associação de frações orgânicas e minerais, ou seja, complexos organominerais, representados pela ligação de um radical orgânico de carga negativa e um mineral de argila também de carga negativa, que é possível pela presença de um cátion polivalente posicionado entre as duas estruturas. Essas estruturas aprisionam os metais, tornando-os, não disponíveis (ALLOWAY, 1995).

A oxidação da matéria orgânica do solo promove uma drástica redução na quantidade de metais adsorvidos. Todos os metais pesados formam compostos pouco solúveis com uma série de ânions facilmente encontrados no solo, tais como carbonato, fosfato e silicato. Entretanto, o fator principal de imobilização desses metais é a formação de complexos polidentados (quelatos) com os componentes húmicos do solo, sendo que a manutenção da matéria orgânica do solo é fundamental para aumentar a retenção de metais pesados (ALLOWAY, 1995).

Os ácidos húmicos e fúlvicos apresentam radicais carboxílicos e hidroxilas que reagem formando quelatos. As formas nativas dos quelatos nos solos originam-se de composto e complexos derivados de substâncias húmicas. Os quelatos são estruturas 
químicas cíclicas em que um elemento metálico central neutraliza as cargas negativas superficiais da matéria orgânica (ALLOWAY, 1995).

Os óxidos e hidróxidos de ferro, alumínio e manganês, retêm os elementos metálicos pesados na forma precipitada nos solos. A formação de complexos metálicos com compostos orgânicos, principalmente ácidos húmicos e fúlvicos, diminui a disponibilidade e toxidez de metais pesados e reduz sua mobilidade no solo (ALLOWAY, 1995).

Assim, restam as frações adsorvidas aos complexos coloidais do solo e aquelas que se encontram solúveis na solução do solo. Estas podem ser absorvidas pelas plantas ou serem lixiviadas para pontos mais baixos, podendo contaminar as águas subterrâneas.

\subsubsection{RETENÇÃO DE METAIS PESADOS}

O conhecimento dos mecanismos de retenção destes metais é de grande utilidade para projetos de contenção de contaminantes. A habilidade dos solos de reterem metais pesados é diretamente proporcional à sua capacidade de tamponamento, ou seja, depende da resistência do solo a variações de $\mathrm{pH}$, assim os mecanismos de retenção são diferentes para $\mathrm{pH}$ distintos.

De acordo com as condições ambientais ( $\mathrm{pH}$, Eh, Temperatura) e a composição dos solos, os metais podem ser retidos sob a forma de óxidos, hidróxidos, carbonatos, cátions trocáveis e ou confinados à matéria orgânica. Estudos com suspensões de caulinita, ilita e montmorilonita puras obtiveram aumento acentuado na capacidade de retenção para metais pesados e, dentre os argilominerais estudados, a ordem de retenção obtida foi a seguinte: Montmorilonita > Ilita > Calinita, o que está de acordo com a disposição dos valores de CTC e superfície específica para estes minerais (YONG et al., 1992).

As características de retenção diferem entre os metais e entre os tipos de solo, pois a preferência de adsorção entre as espécies metálicas não é igual para os diferentes tipos de solo. É necessário entender os mecanismos de adsorção envolvidos na retenção de metais pesados e o papel dos vários constituintes, tanto no solo quanto no chorume contaminante (YONG et al., 1992). 
Espera-se um comportamento competitivo entre os íons de metais pesados por sítios de adsorção no solo, quando várias espécies estiverem associadas num mesmo resíduo de contaminação. YONG et al. (1992) ao realizarem um ensaio de equilíbrio em lote com suspensões de ilita e montmorilonita e soluções de $\mathrm{Pb}, \mathrm{Cu}, \mathrm{Zn}$ e $\mathrm{Cd}$ sob iguais concentrações, adicionou doses sucessivas de um ácido variando de 0 até $200 \mathrm{cmol} \mathrm{H}^{+}$/ $\mathrm{kg}$ de solo. Os resultados destes ensaios apresentaram uma retenção diferente para cada metal e a ordem de seletividade permaneceu igual para solos testados, porém as quantidades retidas e as alterações de $\mathrm{pH}$ foram afetadas pela presença de outros íons metálicos na solução, sendo marcante a característica de retenção da montmorilonita.

A quantidade de metais pesados adsorvidos pelo solo podem ser confrontadas com o pH da solução do solo. Assim, a seletividade na retenção destes metais em um solo a base de ilita foi a seguinte: $\mathrm{Pb}>\mathrm{Cu} \geq \mathrm{Zn} \approx \mathrm{Cd}$; e para a montmorilonita, dois padrões foram obtidos conforme YONG et al. (1992): (1) $\mathrm{pH}$ da solução do solo $\leq 3: \mathrm{Pb}$ $>\mathrm{Cd}>\mathrm{Zn}>\mathrm{Cu}$; e (2) $\mathrm{pH}>3: \mathrm{Pb}>\mathrm{Cu}>\mathrm{Zn}>\mathrm{Cd}(\mathrm{BOFF}, 1999)$.

As diferenças na adsorção seletiva foram induzidas pelas propriedades do solo e dos metais, sendo que o QUADRO 4 a seguir mostra a ordem de seletividade destes, estabelecida para diferentes constituintes do solo.

QUADRO 4 - Adsorção seletiva de metais pesados em diferentes solos

\begin{tabular}{cc}
\hline MATERIAL & ORDEM DE SELETIVIDADE \\
\hline Caulinita (pH 3,5-6) & $\mathrm{Pb}>\mathrm{Ca}>\mathrm{Cu}>\mathrm{Mg}>\mathrm{Zn}>\mathrm{Cd}$ \\
Caulinita (pH 5,5-7,5) & $\mathrm{Cd}>\mathrm{Zn}>\mathrm{Ni}$ \\
Montmorilonita (pH 3,5-6) & $\mathrm{Ca}>\mathrm{Pb}>\mathrm{Cu}>\mathrm{Mg}>\mathrm{Cd}>\mathrm{Zn}$ \\
Montmorilonita (pH 5,5-7,5) & $\mathrm{Cd} \approx \mathrm{Zn}>\mathrm{ni}$ \\
Óxidos de $\mathrm{Al}$ (amorfos) & $\mathrm{Cu}>\mathrm{Pb}>\mathrm{Zn}>\mathrm{Cd}$ \\
Óxidos de Fe (amorfos) & $\mathrm{Pb}>\mathrm{Cu}>\mathrm{Zn}>\mathrm{Cd}$ \\
Ácido Fúlvico (pH - 5) & $\mathrm{Cu}>\mathrm{Pb}>\mathrm{Zn}$ \\
Ácido Húmico (pH 4-6) & $\mathrm{Cu}>\mathrm{Pb}>\mathrm{Cd}>\mathrm{Zn}$ \\
Solos minerais, sem matéria orgânica (pH -5$)$ & $\mathrm{Pb}>\mathrm{Cu}>\mathrm{Zn}>\mathrm{Cd}$ \\
Solos minerais, com 20 - 40 g/kg matéria & $\mathrm{Pb}>\mathrm{Cu}>\mathrm{Cd}>\mathrm{Zn}$ \\
orgânica &
\end{tabular}

FONTE: YONG et al., 1992 (modificado)

Durante a especiação de metais pesados ocorre a formação de complexos com ligantes na fase aquosa, resultando numa competição com os sólidos do solo pela adsorção destes solutos. A presença de vários ligantes no resíduo de lixiviação interfere ná adsorção de metais pesados pelo solo devido à formação de contiplexos solúveis. Este 
comportamento dificulta a previsão do transporte de contaminantes (YONG et al., 1992).

Como exemplo, tem-se a adsorção de íons cloreto $\left(\mathrm{Cl}^{-}\right)$e do cádmio $(\mathrm{Cd})$ pela superfície dos sólidos no solo, tal como em solos com argila caulinítica. A interação entre estes íons é significativa, uma vez que as concentrações típicas de $\mathrm{Cd}^{\mathrm{e}} \mathrm{de} \mathrm{Cl}^{-}$no chorume de aterros sanitários são em média, respectivamente 17 ppm e de 34 à 2800 ppm. Os complexos monomoleculares formados no chorume entre um íon metálico central e vários ânions ligantes podem ser positivos, negativos ou neutros e assumem as seguintes combinações: $\mathrm{CdCl}^{+}, \mathrm{CdCl}^{0}{ }_{2}, \mathrm{Cd} \mathrm{Cl}^{-}{ }_{3}$ e $\mathrm{CdCl}^{2-}{ }_{4}$ e, estas formas de $\mathrm{Cd}$ não são adsorvidas pelo solo (YONG et al., 1992).

\subsubsection{CARACTERÍSTICAS DE ALGUNS METAIS}

De acordo com DAMASCENO (1996), citando diversos outros autores, as principais características de alguns metais são:

\section{Cádmio:}

É um elemento que faz parte do Grupo IIB, com densidade $8,60 \mathrm{~g} / \mathrm{cm}^{3}$ e uma coloração azulada e dúctil. $\mathrm{O}$ estado de oxidação natural é $\mathrm{Cd}^{+2}$. Apresenta covalência moderada e alta afinidade pelos grupos sulfetos, o que leva a um aumento de sua solubilidade em lipídeos, sua bioacumulação e sua toxicidade. O Cd no organismo pode substituir o $\mathrm{Zn}$ em muitas reações, desativando certos complexos enzimáticos (DAMASCENO, 1996).

A utilização do $\mathrm{Cd}$ na indústria é muito variada, é utilizado em indústrias de galvanoplastia, na fabricação de baterias, em tubos de televisores, lâmpadas fluorescetes e como pigmento e estabilizador de plásticos polivinílicos (LARINI, 1993).

No ambiente aquático, o Cd é oxifilico e sulfofilico. Muitos dos tipos de matéria orgânica (como açucares, aminoácidos, polissacarídeos, ácidos hidroxílicos e carboxílicos de natureza aromática e alifática) também possuem doadores para a formação de complexos com esse elemento. As águas não poluídas possuem menos do que $1 \mu \mathrm{g} / \mathrm{L}$ de $\mathrm{Cd}$. A contaminação das águas superficiais pode ocorrer por descarga de resíduos industriais, lixiviação de aterro sanitário, ou de solos que recebem lodo de esgoto (DAMASCENO, 1996). 
Sabe-se que a adsorção deste elemento ao solo aumenta com o pH e, a partir de um pH maior ou igual a 7, praticamente todo o metal é adsorvido (LARINI, 1993).

As principais vias de exposição ao $\mathrm{Cd}$ são os alimentos, a água para consumo humano, ar, cigarros e exposição industrial.

Os efeitos de intoxicação aguda por Cd são muitos sérios e entre eles estão a hipertensão, problemas nos rins, destruição dos tecidos dos testículos e destruição dos glóbulos vermelhos do sangue. Acredita-se que grande parte da ação fisiológica do Cd ocorre devido à sua similaridade a $\mathrm{Zn}$. $\mathrm{O} \mathrm{Cd}$ pode substituir o $\mathrm{Zn}$ em algumas enzimas, causando alterações e impedindo a atividade catalítica de tais enzimas (DAMASCENO, 1996).

\section{Chumbo:}

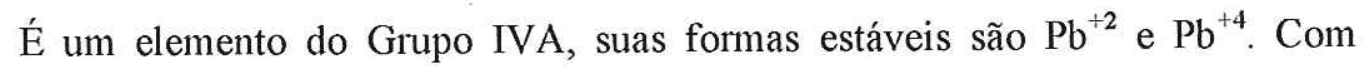
exceção dos nitratos e acetatos, a maioria dos sais de chumbo é insolúvel em água. Possui densidade $11,34 \mathrm{~g} / \mathrm{cm}^{3}$ e é utilizado em larga escala no mundo na fabricação de baterias, aditivos para gasolina, pigmentos, projétil para armas de fogo, soldas, na preservação de madeira, na pintura de barcos, na indústria petrolífera, em óleos lubrificantes e na fabricação de lâminas (DAMASCENO,1996).

$\mathrm{O}$ teor de $\mathrm{Pb}$ em rios e lagos encontra-se na faixa de 1 a $10 \mu \mathrm{g} / \mathrm{L}$, porém valores maiores foram registrados onde a contaminação ocorre como resultado de atividades industriais-(LARINI, 1993).

As principais vias de exposição ao $\mathrm{Pb}$ são água para consumo humano, alimentos, ar, cigarros. A toxicidade aguda causada pelo $\mathrm{Pb}$ provoca várias disfunções nos rins, no sistema reprodutivo, figado, no cérebro e sistema nervoso central. A vítima pode ter dores de cabeça e musculares, sentir cansaço e irritação e a toxicidade moderada pode causar anemia (LARINI,1993).

\section{Cromo:}

É um metal lustroso, branco, rígido e do Grupo VIB.

Possui densidade de $7,19 \mathrm{~g} / \mathrm{cm}^{3}$, é utilizado na fabricação de ligas metálicas empregadas na indústrias de transporte, construções e fabricação de maquinários e de tijolos refratários. Também é utilizado na indústria têxtil, fotográfica, de vidros e é um oxidante no processo de obtenção da sacarina, na purificação de óleos e gorduras e como dessecador em colas, tintas e géis (LARINI, 1993). 
Os níveis de $\mathrm{Cr}$ na água são relativamente baixos $(9,7 \mu \mathrm{g} / \mathrm{L})$, embora níveis maiores já tenham sido relatados como conseqüência do lançamento nos rios de resíduos contendo este metal. $\mathrm{O} \mathrm{Cr}^{+3}$ é um cátion essencial ao ser humano, que se mostra necessário para o metabolismo da glicose, lipídios, para a utilização de aminoácidos em vários sistemas, e também para a prevenção da diabete e arteriosclerose. As principais vias de exposição ao $\mathrm{Cr}$ são água para o consumo humano, alimentos, ar, cigarros (DAMASCENO, 1996).

$\mathrm{O} \mathrm{Cr}^{+6}$ existe somente nas formas de óxidos $\left(\mathrm{CrO}_{3}, \mathrm{CrO}_{4}{ }^{2-} \mathrm{e}^{-} \mathrm{Cr}_{2} \mathrm{O}_{7}{ }^{2-}\right) \cdot \mathrm{O} \mathrm{Cr}^{+6}$ e o $\mathrm{Cr}^{+5}$ são formas intermediárias entre $\mathrm{Cr}^{+3}$ e $\mathrm{Cr}^{+4}$. $\mathrm{O} \mathrm{Cr}^{+2}$ existe, mas se oxida rapidamente, não sendo persistente. $\mathrm{O} \mathrm{Cr}^{+3}$ é mais inerte, porém o estado de $\mathrm{Cr}^{+6}$ é mais tóxico. A forma hexavalente do $\mathrm{Cr}$ é reconhecida como carcinogênica, causando câncer no trato digestivo e nos pulmões, podendo causar também dermatites e úlceras na pele e

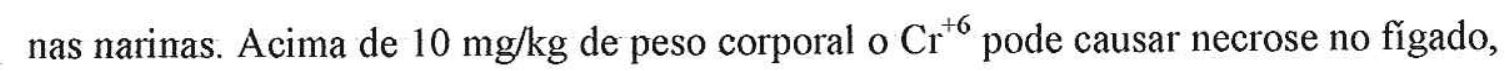
nefrites e morte, e abaixo desse valor pode causar irritação na mucosa gastrointestinal (DAMASCENO, 1996).

\section{Cobre:}

$\mathrm{O} \mathrm{Cu}$ é amplamente distribuído pela natureza no estado livre e também em sulfetos, arsenatos, cloretos e carbonatos. É mole e dúctil, possuindo alta condutividade térmica e elétrica. $\mathrm{O} \mathrm{Cu}$ pertence a terceira série do Grupo dos metais de transição, podendo ser encontrado no estado de oxidação $+1,+2 \mathrm{e}+3$.

É um microconstituinte orgânico importante para os seres vivos. Nas metaloenzimas altamente específicas, ele está fortemente associado às proteínas $\mathrm{e}$, freqüentemente, constitui o centro ativo da célula viva, catalizando somente alguns tipos de reações específicas. $\mathrm{O} \mathrm{Cu}^{+1}$ está presente em enzimas capazes de conduzir o oxigênio, além de ser necessário na formação de substâncias. Porém, acima dos valores permitidos, é um elemento perigoso por ser causador de várias doenças agudas ou crônicas no ser humano (DAMASCENO, 1996).

Ele pode ocorrer nas águas naturais como resultado da atividade das indústrias que usam sais e catalizadores de cobre ou que beneficiam ou laminam este metal. Sua utilização se dá, principalmente, na indústria elétrica de automóveis.

Ele é rapidamente absorvido pelo solo, sendo que este processo depende do tipo de solo, do $\mathrm{pH}$, dos cátions presentes, da presença de ligantes e dos óxidos de Manganês e Ferro. Após o mercúrio, é o metal mais tóxico (DAMASCENO, 1996). 
Níquel:

Tem coloração branco-prateada, é maleável, dúctil e possui boa condutividade térmica e elétrica. Seus estados de oxidação variam de -1 a +4 , mas no estado natural aparece como +2 .

Está classificado entre um ácido intermediário em relação aos seus doadores, refletindo sua abundância na crosta terrestre, associado a carbonatos, óxido, silicatos, ferro, mercúrio, arsenatos, sulfetos e teluriatos. Tem papel fundamental no metabolismo bioquímico e, em excesso, provoca câncer (LARINI, 1993).

Possui densidade de $8,90 \mathrm{~g} / \mathrm{cm}^{3}$ e por ser altamente resistente a corrosão pode ser utilizado na produção de aço inoxidável; na indústria de galvanoplastia; na fabricação de baterias juntamente com $\mathrm{Cd}$ (baterias Ni-Cd) em componentes eletrônicos; produtos de petróleo; pigmentos; fertilizantes e como catalisadores para hidrogenação de gorduras.

Os problemas mais significantes de contaminação de águas com Ni estão associados à descarga de efluentes industriais contendo altos níveis deste metal. Normalmente, o nível de $\mathrm{Ni}$ nas águas superficiais varia entre 5 a $20 \mu \mathrm{g} / \mathrm{L}$ (DAMASCENO, 1996).

As principais vias de expesição ao $\mathrm{Ni}$ são a água para o consumo humano, alimentos, ar, exposição industrial e cigarros. Sabe-se que o Ni é relativamente não tóxice e as concentrações a que o homem encontra-se exposto são aceitáveis (LARINI, 1993).

As concentrações tóxicas de $\mathrm{Ni}$ podem causar muitos efeitos, entre eles, o aumento da interação competitiva com cinco elementos essenciais $(\mathrm{Ca}, \mathrm{Co}, \mathrm{Cu}, \mathrm{Fe}$ e Zn), provocando efeitos mutagênicos pela ligação do Ni aos ácidos nucléicos; efeitos teratogênicos; indução de câncer nasal, pulmonar e na laringe e aparecimento de tumores malignos nos rins (DAMASCENO, 1996).

Zinco:

É um elemento que faz parte do Grupo IIB, tem habilidade de formar complexos com amônia, aminas e cianetos. É um ácido intermediário entre forte e fraco, ou seja, forma complexos com bases fortes (oxigênio) e bases fracas (enxofre). O $\mathrm{Zn}$ é hidrolisado a um $\mathrm{pH} 7,5$ e forma $\mathrm{Zn}(\mathrm{OH})_{2}$ em $\mathrm{pH} 8,0$. Em pH baixo $(6,5)$, complexa com matéria orgânica e com minerais (LARINI, 1993). 
Possui densidade de $7,14 \mathrm{~g} / \mathrm{cm}^{3}$, é empregado na galvanização de produtos de ferro, utilizado em baterias, fertilizantes, lâmpadas, televisores, aros de rodas e também é usado em pinturas, plásticos, borrachas, em alguns cosméticos e produtos famacêuticos.

É um elemento essencial ao ser humano, com uma necessidade diária de 10 a 20 mg, sendo necessário na síntese de proteínas e ácidos nucléicos, bem como na divisão mitótica das células. Esse metal tende a ser menos tóxico que os demais, porém os sintemas de toxicidade por Zn são vômitos, desidratação, dores de estômago, náuseas, desmaios e descordenação dos músculos (DAMASCENO, 1996).

\section{Mereúrio:}

Possui densidade de $13,54 \mathrm{~g} / \mathrm{cm}^{3}$, é utilizado em baterias, termômetros, fungicidas, amalgama dentário e produtos famacêuticos.

Efluentes de esgoto industrial, às vezes, podem conter até 10 vezes o nível de $\mathrm{Hg}$ encontrado em águas naturais.

As vias de absorção do Hg são inalação de vapores, ingestão e absorção cutânea. Os efeitos toxicológicos de $\mathrm{Hg}$ são neurológicos, incluindo irritabilidade, paralisia, cegueira, loucura, quebra de cromossomos e defeitos de nascença (DAMASCENO, 1996).

\section{Manganês-e Ferro:}

O Mn e o Fe são elementos abundantes na crosta terrestre, presentes nas formas insolúveis $\left(\mathrm{Fe}^{3+}\right.$ e $\left.\mathrm{Mn}^{4+}\right)$ numa grande quantidade de tipos de solos e, por isso seus compostos são encontrados por todos os corpos de água, mesmo em concentrações reduzidas. $\mathrm{Na}$ água, podem estar sob a forma reduzida ou oxidada, suspensa, adsorvida a partículas e complexada a substâncias orgânicas. Em pH abaixo de 7,5, com baixas concentrações de $\mathrm{O}_{2}$ e baixo potencial redox, ocorre redução de $\mathrm{Fe}^{3+}$ para $\mathrm{Fe}^{2+}$. A forma reduzida de Fe torna-se solúvel sob a forma de bicarbonato $\left(\mathrm{Fe}(\mathrm{HCO} 3)_{2}\right)$ ou como íons $\mathrm{Fe}^{3+}$ em equilíbrio com o hidróxido de ferro, após sua oxidação (CRHISTENSEN et al., 2001).

A forma reduzida de $\mathrm{Fe}$ precipita-se sob a forma de $\mathrm{Fe}(\mathrm{OH})_{2}, \mathrm{FeCO}_{3}$ e $\mathrm{FeS}$. O $\mathrm{Mn}$ reage de maneira semellhante ao ferro, precipitando como $\mathrm{MnCO}_{3}, \mathrm{MnS}$ e $\mathrm{Mn}(\mathrm{OH})_{2}$ e solubiliza-se como $\mathrm{Mn}\left(\mathrm{HCO}_{3}\right)_{2}$. A diferença é que $\mathrm{MnS}$ não é tão solúvel quanto $\mathrm{FeS}$ 
(CHRISTENSE et al., 2001). Não foi encontrado na literatura relatos com toxicidade causadas por Fe e Mn.

Macrocomponentes:

São chamados de macrocomponentes os íons Sódio (Na), Cálcio (Ca), Potásio $(\mathrm{K})$, Magnésio $(\mathrm{Mg})$, Sulfato $\left(\mathrm{SO}_{4}\right)$, Cloreto $(\mathrm{Cl})$ e Ácido Carbônico $\left(\mathrm{HCO}_{3}\right)$ que compreendem mais do que $90 \%$ dos existentes na águas naturais. Eles estão normalmente presentes em concentrações maiores que $1 \mathrm{mg} / \mathrm{L}$ em chorumes e/ou águas subterrâneas. (FREEZE \& CHERRY, 1979).

Estes macrocomponentes não constituem um problema muito severo de poluição para as águas de subsuperfície. Contudo, os padrões de qualidade da água potável normalmente incluem a maior parte desses componentes e, freqüentemente, as concentrações no chorume excedem significativamente estes padrões. Além disso, alguns desses componentes são importantes no controle do ambiente redox e na atenuação dos metais pesados (CHRISTENSEN et al., 1992a).

O Potássio é um elemento do primeiro grupo da tabela periódica (metais alcalinos), sendo muito solúvel em água. Possui propriedades semelhantes ao Sódio, com o qual normalmente está agrupado. Estes não se encontram livres na natureza e são abundantes em rochas constituídas por silicatos complexos com feldspatos e ortoclásio. Também aparecem em grandes quantidades em zonas áridas ou constituindo depósitos litorâneos nas formas de sulfatos, nitratos, cloretos, carbonatos, bórax, entre outros (LAFUENTE, 1996).

Segundo CHEREMISINOFF (1995), o Potássio está freqüentemente presente em pequenas quantidades nas águas naturais, já que são adsorvidos pelas ilitas, sendo que uma das fontes de contaminação que elevam bruscamente o teor deste são os resíduos da industrialização da beterraba.

O Potássio, assim como o Sódio, têm alta concentração em corpos fluídos e estão amplamente distribuídos por todo o corpo humano, não sendo considerados como elementos traço, mas sim macrocomponentes. Por serem bastante móveis, eles participam na condução de impulsos nervosos para o cérebro (FÓRSTNER \& WITTMANN, 1981).

O Cloreto $\left(\mathrm{Cl}^{-}\right)$, juntamente com os bicarbonatos $\left(\mathrm{HCO}^{3-}\right)$, carbonatos $\left(\mathrm{CO}_{3}{ }^{2-}\right)$ e sulfatos $\left(\mathrm{SO}_{4}{ }^{2-}\right)$ são considerados os ânions predominantes em águas naturais (KNOX et al., 1993). Considera-se que o Cloreto não sofra qualquer reação química ou físico- 
química em aquíferos e, como tal, é considerado inerte ou conservativo (CHRISTENSEN et al., 1992a).

\subsection{TRANSPORTE DE CONTAMINANTES EM MEIO POROSO}

Na previsão dos impactos de uma área de disposição de resíduos sólidos é necessário o conhecimento dos mecanismos e parâmetros de transporte de contaminantes envolvidos. A migração de contaminantes em meios porosos é governada por diversos processos, dentre os quais destacam-se os processos físicos que envolvem os fenômenos de advecção e dispersão hidrodinâmica, e também os químicos, que englobam as diversas reações químicas que ocorrem entre a solução contaminada e o solo, implicando em ganho ou perda de massa do soluto para o solo (OLIVEIRA, 2002).

O conhecimento dos efeitos decorrentes da atenuação destes fenômenos é grande, entretanto há carência de informações quanto à natureza dos processos envolvidos. Estes processos ocorrem de forma simultânea, de maneira que a predominância de um- processo depende das condições físicas e químicas do meio envolvido. A seguir serão mostrados alguns dos processos físicos e químicos que controlam o transporte de substâncias solúveis através do meio poroso.

\subsubsection{MECANISMOS FÍSICOS DE TRANSPORTE}

Os principais mecanismos físicos que governam o transporte de contaminantes miscíveis estão relacionados com processos de transporte de solutos que são Advecção e Dispersão Hidrodinâmica (dispersão mecânica e difusão molecular).

\subsubsection{ADVECÇÃO}

FREEZE \& CHERRY (1979) definem a advecção como componente do movimento do soluto atribuído ao transporte pela água em fluxo, onde a taxa de transporte de soluto está relacionada com a velocidade da água no meio poroso. Portanto, considera-se o estudo da advecção como a avaliação do próprio movimento da água nos meios porosos. 
A advecção é um mecanismo de transporte, por meio do qual a migração do soluto ocorre devido ao fluxo hidráulico do fluído em que está dissolvido. No transporte advectivo de solutos que não interagem com o meio poroso, a frente de contaminação é abrupta e move-se a uma velocidade igual à velocidade do fluído percolante, geralmente a água, sem que seu pico de concentração seja alterado (BEAR,1972).

\subsubsection{DISPERSÃO HIDRODHNÂMHCA}

É o fenômeno responsável pelo espalhamento do poluente no meio poroso, constitui-se na tendência ao espalhamento do soluto nos caminhos pelos quais este percorre e, como resultado do espalhamento, ocorre expansão e diluição da pluma de contaminação. Embora a massa total do contaminante não varie, a pluma ocupa um volume maior no meio poroso (BEAR, 1972).

A dispersão hidrodinâmica é o aspecto macroscópico dos movimentos das moléculas e íons dissolvidos através dos poros e dos vários fenômenos físicos e químicos que ocorrem dentro dos poros. A dispersão hidrodinâmica possui duas componentes: a dispersão mecânica e a difusão molecular (BEAR, 1972).

A dispersão mecânica é um processo de mistura mecânica que ocorre em função das variações locais da velocidade de fluxo do fluído dentro do meio poroso (BEAR, 1972), portanto é causada pelo movimento do fluído.

Com o passar do tempo, uma determinada pluma torna-se mais dispersa, à medida que diferentes porções do soluto são transportadas com diferentes velocidades, devido à heterogeneidade do meio (FREEZE e CHERRY, 1979).

Medindo-se a concentração do efluente ao longo do tempo e traçando o resultado em um gráfico em termos de concentração relativa $(\mathrm{Ce} / \mathrm{Co})$ em função da razão entre o volume percolado (VP) e o volume de vazios da amostra (Vv), obtém-se a curva normalizada da FIGURA 2. Esta é denominada Curva Característica de Transporte ou, mais freqüentemente, é utilizado o termo inglês breakthrough curve (OLIVEIRA, 2002). 


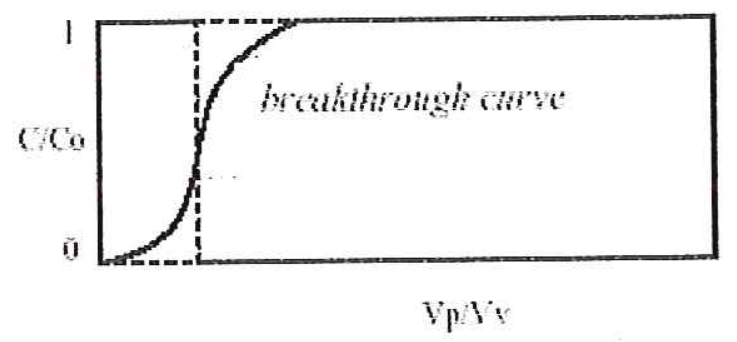

FIGURA 2 - Variação da concentração do efluente - Curva Característica de Transporte ou Breakthrough curve FONTE - OLIVEIRA (2002)

A partir dessa curva os parâmetros que controlam a dispersão hidrodinâmica e o retardamento podem ser determinados.

A difusão molecular é o processo irreversível no qual os constituintes iônicos e moleculares se movem sob a influência da energia cinética na direção do gradiente de concentração, portanto é a mistura causada por movimento molecular aleatório devido à energia cinética do soluto (FREEZE e CHERRY, 1979). Uma vez estabelecido o gradiente, as moléculas e íons-tendem a se deslocar das regiões de maior concentração para as de menor, visando equalizar a concentração em toda a massa do fluído, sendo que o transporte difusivo ocorre mesmo na ausência de fluxo hidráulico. $)$

A presença de partículas de solo dificulta o processo de difusão, uma vez que, este envolve o movimento das espécies de interesse na água presente nos poros, entre essas partículas (ROWE et al., 1995).

No meio poroso, a difusãe é menor do que em soluções livres devido à tortuosidade das trajetórias de fluxo; pequeno volume de fluído para o fluxo (porosidade); retenção de íons e moléculas nas superfícies das partículas (retardamento); biodegradação de solutos orgânicos; ente outros (ROWE et al., 1995).

Em solos de textura fina, de baixa condutividade hidráulica e velocidades de fluxo, a difusão molecular se torna o principal mecanismo de contaminação, excedendo até o efeito da advecção (OLIVEIRA, 2002).

\subsubsection{MECANISMOS QUIIMICOS QUE INFLUENCIAM O TRANSPORTE}

As reações químicas que podem alterar a concentração do soluto no fluído percolante, ou seja, os processos químicos que afetam o transporte de contaminantes inorgânicos nos materiais em subsuperficie são a sorção/dessorção, a troca iônica, a 
complexação, a oxidação/redução e a especiação (dissolução/precipitação) conforme FREEZE e CHERRY (1979).

\subsubsection{SORÇÃO/DESSORÇÃO}

São os dois mecanismos de maior importância que afetam o transporte de contaminantes e, por isso os mais estudados.

A sorção é definida como a migração de um soluto (íon, moléculas e compostos) para a interface de uma partícula sólida e a dessorção é a remoção. As interfaces de maior interesse para o destino e transporte de solutos em subsuperfície são líquido/sólido e gás/sólido. Assim, o termo sorção envolve adsorção (acumulação de um soluto numa interface) e absorção (partição entre duas fases) segundo KNOX et al. (1992).

Devido à complexidade e dificuldade de discernimento entre várias reações, YONG et al. (1992) recomendam a utilização do termo sorção para caracterizar o processo geral em que os solutos (íons, moléculas e demais compostos) são repartidos entre a fase líquida e sólida do solo. Estes autores defendem a idéia de que quando a distinção entre os mecanismos de atenuação é dificil, o termo sorção deve ser utilizado.

YONG et al. (1992) distinguem três mecanismos presentes nos processos de transferência (adsorção) ou remoção (dessorção) de soluto da fase aquosa do sistema solo-contaminante: Troca Iônica (acumulação do soluto em um sítio de sorção por atração eletrostática entre carga do solo e do soluto); Adsorção Física (resultado da atração de Van de Waals ou de forças similares, onde contaminantes em solução são atraídos pelas partículas do solo, em resposta ao desequilíbrio de cargas) e Adsorção Química (resulta de uma reação química entre superfície do sólido e o soluto, ou seja, um tipo de reação específica através da qual ocorre ligação de elementos da fase líquida na sólida, por ligações covalentes).

A adsorção é um dos mais importantes processos químicos que ocorrem nos solos, determinando a quantidade de nutrientes, metais, pesticidas e outros químicos orgânicos que são retidos nas superfícies dos sólidos e, é também um dos principais processos que afeta o transporte de nutrientes e contaminantes nos solos (OLIVEIRA, 2002). 
BOFF (1999) cita que os pricipais fatores que controlam a capacidade de adsorção do solo são: a superfície específica dos minerais constituintes, conteúdo de argila, matéria orgânica (\% C) e óxidos e hidróxidos de Fe e Al.

$\mathrm{O}$ processo de adsorção no solo consiste na adesão de íons e moléculas do fluído na superfície dos sólidos, especialmente partículas da fração argila, pois estas têm uma carga elétrica alta, devido à sua grande área superficial (FREEZE e CHERRY, 1979).

A fração argila inclui, além dos argilominerais que possuem estrutura cristalina definida, de silício, alumínio e oxigệnio (alumino-silicatos), também os materiais inorgânicos não cristalinos (sesquióxidos - óxidos de alumínio e ferro hidratados) e matéria orgânica (OLIVEIRA, 2002).

A quantidade de cátions necessários à neutralização das partículas é denominada Capacidade de Troca Catiônica (CTC), sendo uma propriedade do mineral utilizada para avaliar a capacidade do solo em reter e trocar cátions. Na TABELA 1 estão relacionados os valores de superfície específica e capacidade de troca catiônica dos principais componentes das frações argila, silte e areia dos solos (OLIVEIRA, 2002).

TABELA 1 - Superfície específica e capacidade de troca catiônica dos principais componentes das frações argila, silte e areia dos solos

\begin{tabular}{ccc}
\hline Mineral ou Partícula & $\begin{array}{c}\text { Superfície específica } \\
\left(\mathrm{m}^{2} / \mathrm{g}\right)\end{array}$ & $\begin{array}{c}\text { CTC } \\
(\mathrm{cmol} / \mathrm{Kg} \text { ou meq/100g) }\end{array}$ \\
\hline Caulinita & $10-20$ & $3-15$ \\
Ilita & $70-120$ & $10-40$ \\
Clorita & $79-150$ & $10-40$ \\
Vermiculita & $300-500$ & $100-150$ \\
Esmectita & $700-800$ & $60-150$ \\
Silte & $<1$ & Muito pequena \\
Areia fina & $<0,1$ & Muito pequena \\
Areia grossa & $<0,01$ & Muito pequena \\
\hline
\end{tabular}

Fonte: VIEIRA, 1975

\subsubsection{TROCA IÔNICA}

Normalmente, o principal mecanismo de retenção de íons dissolvidos é a troca iônica, processo reversível em que íons previamente retidos na fase sólida são substituídos por outros que tenham maior afinidade com o mineral, compensando a carga desequilibrada na superfície das partículas. Como a carga líquida das superfícies é usualmente negativa, os íons atraídos às superficies são cátions (FREEZE e CHERRY, 1979). 
A principal diferença entre adsorção e troca iônica reside nas equações modelo. $\mathrm{Na}$ adsorção, a equação utiliza a concentração de um elemento químico, enquanto nas equações de troca envolvem vários. Também há dificuldade de discernimento entre esses dois-processos e os demais- que ocorrem nos sólidos, sendo que a maior diferença está no fato de que as reações de adsorção e troca iônica são somente limitadas pela capacidade de adsorção (e/ou troca) do solo, enquanto as outras envolvem condições de temperatura e pressão como agentes de variação (BOFF, 1999).

A troca iônica é uma categeria da adserção que envolve íons de cargas opostas aos sólidos do solo, também chamados de contra-íons. O excesso de contra-íons que recobre os demais f́ons de mesmo sinal são denominados de íons trocáveis e a capacidade de troca de cátions do sistema é o número máximo desses contra-íons presentes- numa dupla camada elétrica por unidade de troca sob um determinado conjunto de condições em solução (YONG et al., 1992).

As reações- de troca iônica ocorrem em constituintes do solo, como em frações argilosas e não argilosas. O soluto na água dos poros que reage com a superfície da partícula do solo incluem cátions, ânions e moléculas-não iônica (YONG et al., 1992)

A seletividade de troca de íons na superficie carregada dos solos é em função da valêneia e dos-raios iônieos- dos elementos envolvidos. Os íons de mesma valência, porém com raios iônicos diferentes, possuem poder de troca mais elevado do que aqueles com tamanhos maiores e assim os cátions podem ser arranjados em uma série que retrata seu poder de substituição. Embora a posição nesta série dependa do tipo de argila e íon que está sendo substituído, de acordo com KNOX et al. (1993) os cátions tendem a se apresentarem arranjados na seguinte ordem de aumento da força de substituição: $\mathrm{Na}^{+}<\mathrm{Li}^{+}<\mathrm{K}^{+}<\mathrm{Rb}^{+}<\mathrm{Cs}^{+}<\mathrm{Mg}^{2+}<\mathrm{Ca}^{2+}<\mathrm{Ba}^{2+}<\mathrm{Cu}^{2+}<\mathrm{Al}^{3+}<\mathrm{Fe}^{3+}<$ $\mathrm{Th}^{4+}$.

As reações de troca iônica que criam interações entre cargas superficiais, íons e moléculas (solutos) na água do solo, não afetam as cargas nas superfícies ativas, mas as reações de adsorção que ocorrem em superficie são importantes no desenvolvimento de processos de retenção de contaminantes (YONG et al., 1992). 


\subsubsection{COMPLEXAÇÃO, PRECIPITAÇÃO, REAÇÕES REDOX E ÁCIDO/BASE}

A complexação é um processo que ocorre quando um cátion metálico reage com um ânion que funciona como um ligante e, assim, os metais podem ser complexados pelos ânios $\mathrm{OH}^{-}, \mathrm{Cl}^{-}, \mathrm{SO}_{4}{ }^{2-}, \mathrm{CO}_{3}{ }^{2-}, \mathrm{PO}_{3}{ }^{3-}, \mathrm{CN}^{-}$, que se comportam como ligantes (YONG et al., 1992).

A precipitação é o principal agente de retenção dos metais pesados e ocorre quando o soluto migra da fase aquosa para a superficie das partículas, resultando na formação de uma nova substância solúvel. Uma alteração nas condições de pH, potencial redox, concentração dos elementos traços, tempo, temperatura, pode fazer com que as substâncias químicas inorgânicas mudem sua forma. A forma do elemento tem grande impacto na mobilidade, reatividade e toxicidade química (ROWE et al., 1995).

Portanto, a precipitação é o processo em que espécies dissolvidas são desprendidas da solução e que só ocorre quando condições de supersaturação existem, ou seja, a concentração da solução é relativamente alta, de forma que seu grau de solubilidade é excedido (ROWE et al., 1995).

$\mathrm{O}$ pH afeta a precipitação e a dissolução de óxidos e hidróxidos (quando o $\mathrm{OH}^{-}$ atua como agente precipitador). Com valores de $\mathrm{pH}$ altos, os mecanismos de precipitação dominam e a quantidade de metais pesados sorvidos em solos argilosos aumenta. Assim, os metais pesados podem ser removidos do solo através da precipitação, como hidróxidos e carbonatos, ou por coprecipitação, como óxidos e hidróxidos de ferro e manganês. Com o decréscimo do $\mathrm{pH}$, os mecanismos de precipitação se tornam menos importantes e a troca de cátions (dessorção e dissolução) predomina. Os metais pesados ganham mobilidade e a adsorção nas partículas de solo argiloso decresce efetivamente, devido à competição nos locais de troca com o $\mathrm{H}^{+}$ (YONG et al., 2001).

Assim, pode-se observar que o $\mathrm{pH}$ e potencial redox (Eh) são as variáveis dominantes no controle do potencial de liberação de poluente fornecidos à fase aquosa, sua dispersão no ambiente e disponibilidade para biota.

Essas variáveis (pH e Eh), juntamente com as substâncias orgânicas e ligantes inorgânicos, são importantes no controle das formas e da solubilidade dos cátions de metais pesados em plumas de lixiviação. Na ausência de matéria orgânica, os principais 
compostos que governam as trajetórias de solubilidade dos metais pesados são os sulfetos e carbonatos. Para alguns metais, os fosfatos, óxidos e hidróxidos podem limitar a solubilidade (CHRISTENSEN et al., 1992a).

Sob condições oxidantes à ligeiramente redutoras em $\mathrm{pH}$ alcalino, a solubilidade dos cátions de metais pesados decresce devido à precipitação de óxidos, hidróxidos, sulfatos ou carbonatos. Em valores de $\mathrm{pH}$ neutros ou moderadamente alcalinos em condições redutoras, formas amorfas ou cristalinas são reduzidas geralmente pelo enxofre. O tipo de produto de precipitação pode ser determinado a partir das relações de estabilidade em diagramas de $\mathrm{Eh}-\mathrm{pH}$, sendo que os elementos mais importantes no controle da solubilidade do íon metálico em sistemas naturais são o enxofre e o carbono (BOFF,1999).

Na presença de oxigênio livre (valor positivo para potencial de redução padrão) $\mathrm{Me}^{2+}$ (metal com valência $2+$ ) é estável em valores de $\mathrm{pH}$ menores do que 7 a 8 . Com o aumento do $\mathrm{pH}$, o carbonato e o hidróxido tornam-se as fases estáveis. Para valores negativos do potencial de redução, o sulfeto permanece na fase estável sobre uma ampla variação de $\mathrm{pH}(\mathrm{BOFF}, 1999)$.

\subsection{ENSAIOS DE COLUNA}

São ensaios clássicos que reproduzem os processos de interação entre um fluído e um material qualquer, fornecendo estimativas dos parâmetros envolvidos. Em aplicações geoambientais, o objetivo básico da avaliação desse processo é definir o comportamento dos fluídos contaminantes no solo, esteja ele em estado natural ou modificado, fornecendo subsídios imprescindíveis para construção e avaliação dos liners (TRESSOLDI, 2002).

YONG et al (2001) citam que estes ensaios são destinados a vários propósitos:

1) Estudar a adsorção e atenuação de contaminantes;

2) Determinação (estimativa) do número de volumes de poros necessários para a chegada de um contaminante;

3) Obtenção das informações necessárias para o cálculo dos parâmetros de retardamento, utilizados nos modelos de transporte de contaminantes;

4) Determinação (estimativa) dos parâmetros de transporte (dispersão/difusão molecular) que controlam a migração de contaminantes no solo. 
Geralmente nos ensaios de coluna são utilizados dispositivos simples, para anulação do efeito de alguns parâmetros, controle e quantificação de outros, dependendo da finalidade para qual se destina o ensaio. A complexidade do sistema aumenta à medida que novos parâmetros vão sendo acrescentados à analise. Sistemas complexos envolvendo soluções com grande variedade de contaminantes e grande heterogeneidade do solo necessitam de grandes aparatos para controle e mensuração dos parâmetros, além de grande experiência no tratamento e interpretação dos dados (TRESSOLDI, 1991).

Na maioria dos estudos de contaminação em solos, as colunas são construídas de maneira geral, em três partes: o reservatório-fonte, onde se coloca a solução contaminante; a intermediária, onde se coloca o corpo de solo e o reservatório de coleta, onde o fluído que percolou no solo é amostrado. Os dados da contaminação do solo são obtidos pelo monitoramento da concentração do contaminate no reservatório-fonte e também através da análise dos seus teores presentes na amostra de solo (BOFF, 1999).

TRESSOLDI (2002) apresenta alguns procedimentos mais utilizados para ensaios de coluna:

1) Técnicas associadas ao solo (amostragem, peneiramento, umedecimento, empacotamento, entre outros);

2) Técnicas associadas às soluções influentes (coleta de resíduos líquidos anaeróbios, manutenção da estabilidade das soluções durante a operação dos equipamentos para fluídos diferentes, entre outros);

3) Técnicas associadas aos efluentes (amostragem, preservação das amostras, análises química, entre outros);

4) Tratamento dos dados (curvas de chegada, atenuação, movimento dos poluentes, incorporação de variáveis, entre outros);

5) Previsão do movimento dos poluentes, aplicação direta das curvas de chegada e desenvolvimento de modelos de equações universais.

É importante salientar que as etapas acima descritas possuem um sentido generalístico, sendo que os procedimentos diferem muito, dependendo da finalidade para que o ensaio se dispõe.

Uma variedade de aparatos podem ser utilizados nos ensaios de coluna, porém todos eles seguem o mesmo princípio - contato entre contaminante e solo. Assim, como os procedimentos diferem para cada aplicação, o mesmo ocorre quanto aos 
dispositivos utilizados e os equipamentos variam conforme os tipos de líquidos em estudo (BOFF, 1999).

Os métodos utilizados para o cálculo dos parâmetros de transporte de contaminantes em experimentos de coluna classificam-se em estáveis e transientes (YONG et al., 2001). Nos métodos estáveis não há fornecimento de contaminante após o início do ensaio, enquanto nos transientes, o abastecimento de contaminantes na fonte é contínuo.

A diminuição da concentração na fonte é um dos métodos estáveis que tem grande aplicação no estudo da difusão molecular. Neste ensaio o fluxo é impedido de chegar até o extremo inferior da coluna (YONG et al., 2001).

Como exemplo de um método transiente, cita-se o ensaio de percolação do solo por fluídos contaminantes, em que o gradiente hidráulico é controlado e a coleta de amostras é regular. Os resultados obtidos são apresentados sob a forma de diagramas de curvas características de transporte (breakthrough curves) que são construídas através da -relação concentração relativa (Concentração no reservatório de coleta/Concentração inicial) versus número de volume de poros (VP) e tempo (LEITE, 1997).

\subsection{CONSIDERAÇÕES FINAIS}

De acordo com observado na literatura, a disposição final de resíduos sólidos vem ocorrendo de forma inadequada e descontrolada, sem maiores preocupações por parte dos governantes, onde essa realidade terá que ser alterada se há a intenção de preservação das águas superficiais e subterrâneas.

Portanto apesar da tendência de evolução dos aterros, de depósitos abertos e incontrolados à instalações projetadas para minimizar o impacto potencial adverso dos resíduos no ambientes, a geração de percolados permanece como conseqüência indesejável e, inevitável.

A possibilidade de atenuação natural dos contaminantes do chorume a partir de sua percolação no solo tem sido verificada, onde, na ausência de riscos ambientais, ela poderia representar uma alternativa de remediação. E, também, a constatação de sua ocorrência, permitiria sua exploração como propriedade e parâmetro para escolha de substratos de aterros. Baseado nessa possibilidade, este trabalho vem avaliar a capacidade atenuadora do solo em reter contaminantes presentes em líquidos percolados 
de aterro sanitário, de forma a aplicar seus resultados em medidas de prevenção da degradação ou até remediação dos ambientes adjacentes ao aterro.

Para avaliação da atenuação de chorume em solo é indicado teste em colunas por refletirem melhor as condições naturais e as características adsortivas destes, - propiciando uma melhor simulação da atenuação. 


\section{METODOLOGIA}

A seguir serão apresentadas as metodologias empregadas para elaboração deste trabalho.

\subsection{COLETA DE SOLO}

Foram coletadas amostras de solo no Aterro Sanitário do município de São Carlos/SP, à Rodovia Washington Luiz km 231, distanciado cerca de $12 \mathrm{~km}$ do centro urbano, com uma área total de $70.000 \mathrm{~m}^{2}$, altitude média de $763 \mathrm{~m}$ nas coordenadas $21^{\circ}$ 56' 57,9' latitude Sul e 47 $55^{\prime} 17,1^{\prime}$ ' longitude oeste de Greenwich, georreferenciadas utilizando sistema de posicionamento global (GPS) de navegação, marca Garmin, Modelo Etrex Vista.

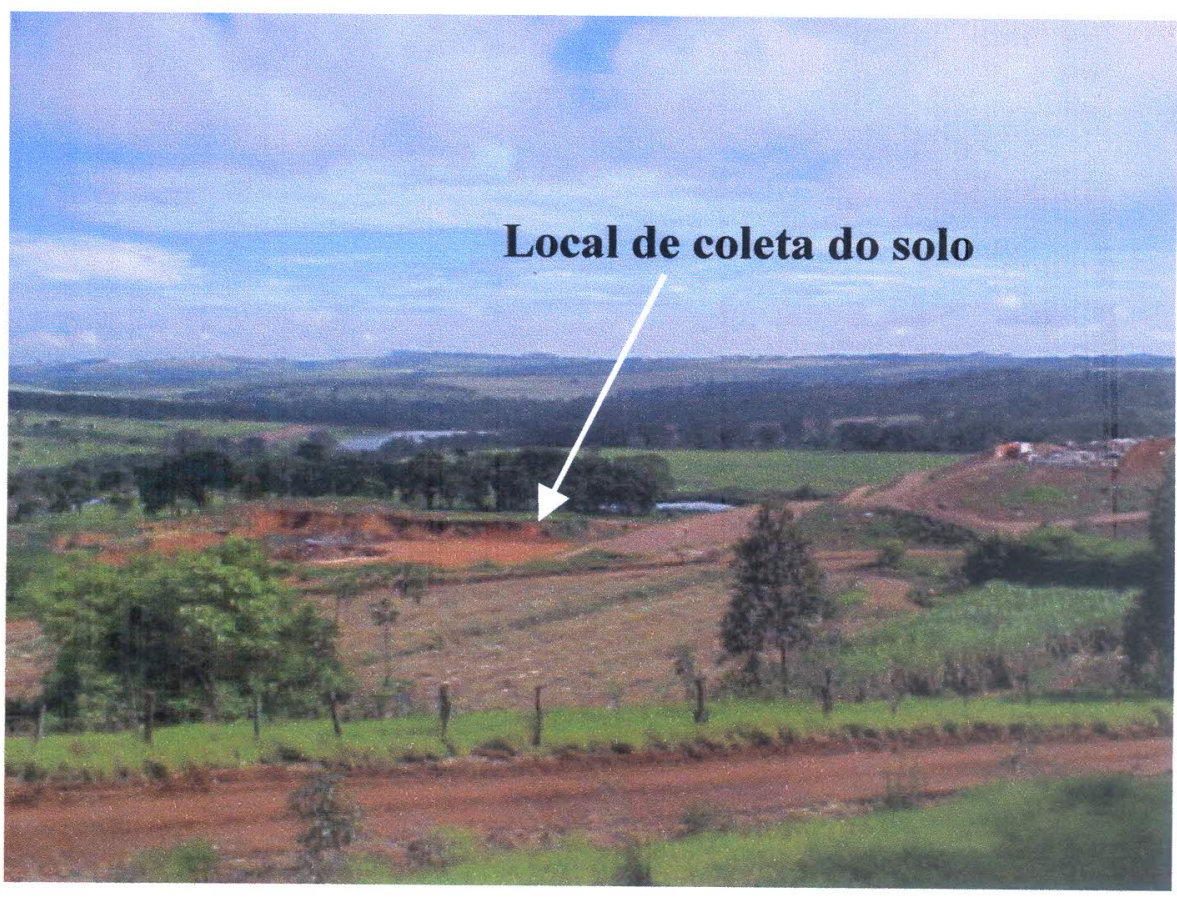

FIGURA 3 - Aterro sanitário de São Carlos: Local de coleta do solo $(15 / 11 / 2004)$ 
As amostras foram coletadas em pontos previamente selecionados e localizados na base do aterro, desprezando-se a cobertura superficial, para atenuar os efeitos de substâncias indesejáveis, como matéria orgânica e resíduos de ação antrópica.

As amostras coletadas foram preparadas e submetidas às análises físicas, ou seja, para determinação de parâmetros físicos do solo, como granulometria, massa específica dos sólidos ( $\rho s)$, umidade (w). A partir desses parâmetros, determinados em laboratório, foram calculados demais parâmetros por relação massa/volume, como porosidade (n), índice de vazios (e), grau de saturação (Sr), massa específica do solo $(\rho)$ e volume de poros ou de vazios (VP). Foram feitas, também, análises químicas do solo coletado, a fim de caracterizar a capacidade de troca catiônica (CTC), superfície específica (SE), potencial hidrogeniônico $(\mathrm{pH})$, condutividade elétrica (CE) e os teores de metais pesados em condição natural.

As análises laboratoriais foram realizados no laboratório de Solos do Departamento de Geotecnia da Escola de Engenharia de São Carlos.

Sabendo-se que a confiabilidade dos resultados dos ensaios dependem da qualidade e da representatividade da amostra retirada do solo, foram tomados os devidos cuidados durante a amostragem para manter a estrutura, o teor de umidade e a textura do solo amostrado.

Foram coletados dois tipos de amostras para execução dos ensaios de laboratório: amostras deformadas (amostras representativas dos solos quanto a textura e constituição mineral, as quais não conservam a estrutura do solo in situ, nem a umidade do mesmo, no local e data da amostragem) e indeformadas (amostras representativas do solo quanto à estrutura, umidade, constituição mineralógica e as demais mencionadas para as amostras deformadas). Ambos os tipos de amostras - deformadas e indeformadas - foram pré-tratadas e ensaiadas para as determinações físicas, conforme normas da Associação Brasileira de Normas Técnicas (ABNT 1984a, 1984b, 1986a, 1986b).

As amostras deformadas foram utilizadas para os ensaios de classificação granulométrica e massa específica dos sólidos. Foram coletados cerca de $50 \mathrm{Kg}$ de solo com auxilio de uma pá e as amostras foram acondicionadas em sacos plásticos e transportados ao laboratório do Núcleo de Estudo e Pesquisa em Resíduos Sólidos (NEPER) localizado no Centro de Recursos Hídricos e Ecologia Aplicada (CRHEA) do Departamento de Hidráulica e Saneamento da Escola de Engenharia de São Carlos USP. 


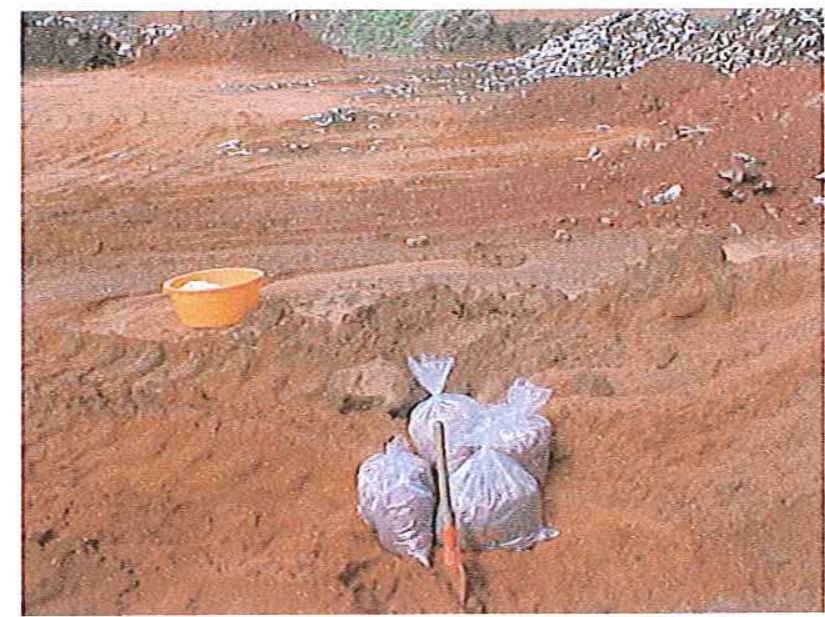

FIGURA 4 - Solo coletado na base do aterro (amostras deformadas) (15/11/2004)

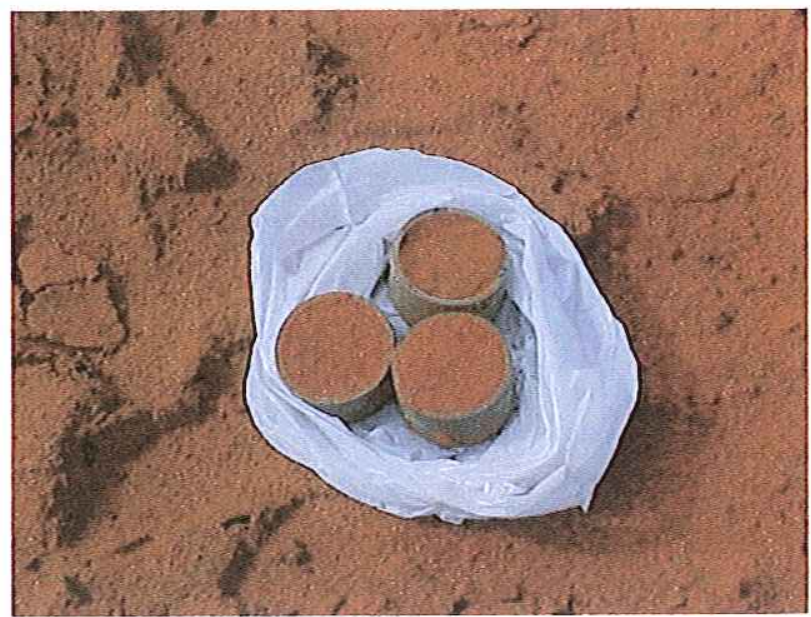

FIGURA 5 - Solo coletado na base do aterro

(amostras indeformadas) (15/11/2004)

No laboratório, para destorroamento e homogeneização, o solo foi colocado sobre lonas plásticas, submetido à secagem ao ar e à sombra, peneirado e, posteriormente, quarteado. Vale ressaltar que no campo, o solo coletado apresentou coloração bastante avermelhada, denotando a presença de óxidos de $\mathrm{Fe}$ e $\mathrm{Al}$.

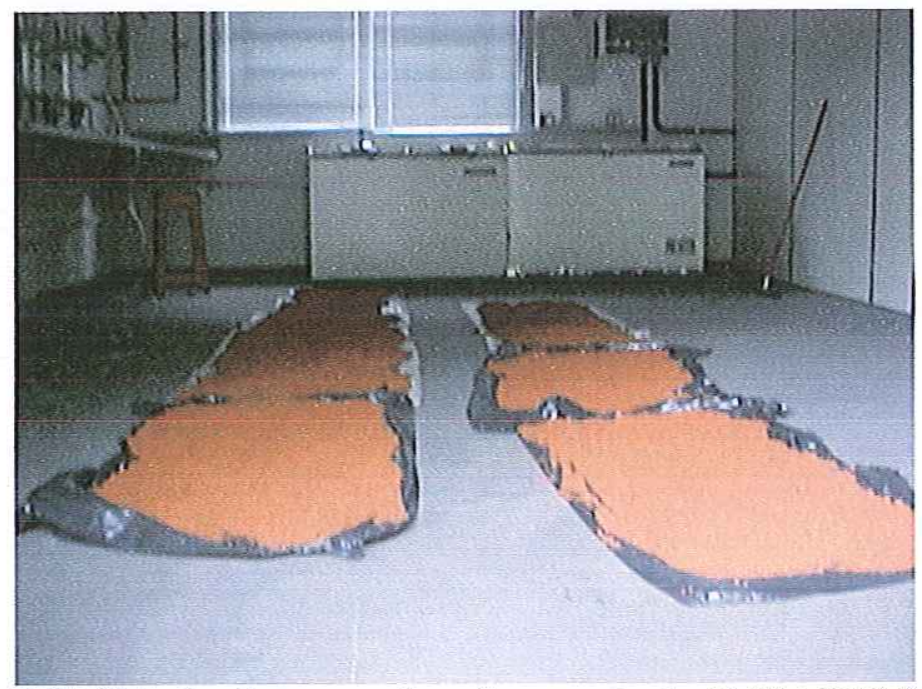

FIGURA 6 - Secagem do solo amostrado (15/11/2004)

As amostras indeformadas foram utilizadas para determinar as características do solo in situ, quanto aos índices físicos. As amostras foram retiradas do local através de amostradores especiais. Segundo NOGUEIRA (1995), esses amostradores são anéis com dimensões de 7,54 cm de diâmetro e uma ponta biselada, os quais durante a amostragem foram inseridos voltados para baixo e pressionados com o objetivo de penetrar no solo. Para que os anéis pudessem ser retirados do solo, foram feitos cortes 
horizontais por baixo das peças e, após retirados, as superfícies foram aparadas. A umidade do solo foi mantida com a colocação de papel filme de polietileno em toda a volta dos anéis.

\subsection{CARACTERIZAÇÃO FÍSICA DO SOLO}

Nesta etapa foram realizados ensaios necessários ao experimento de percolação, sendo que o resumo dos valores dos parâmetros resultantes da caracterização física, bem como as respectivas normas e detalhes sobre os procedimentos de ensaio, estão apresentados no TABELA 2. Maiores detalhes sobre os procedimentos de ensaio podem ser encontrados em NOGUEIRA (1995).

TABELA 2 - Propriedades físicas do solo amostrado

\begin{tabular}{c|c|c}
\hline Propriedades & Método & $\begin{array}{c}\text { Valor da } \\
\text { Propriedade }\end{array}$ \\
\hline Massa Específica dos Sólidos $\rho_{\mathrm{s}}$ & ABNT MB 28 & 2,68 \\
\hline Granulometria & & \\
Argila $(<0,002 \mathrm{~mm})$ & & $0 \%$ \\
Silte $(0,002-0,075 \mathrm{~mm})$ & & $6 \%$ \\
Areia Fina $(0,075-0,42 \mathrm{~mm})$ & ABNT MB 32 & $34 \%$ \\
Areia Média $(0,42-2 \mathrm{~mm})$ & & $41 \%$ \\
Areia Grossa $(>2 \mathrm{~mm})$ & & $19 \%$ \\
\hline Umidade & ABNT MB 33 & $10,65 \%$ \\
\hline
\end{tabular}

A partir destes parâmetros determinados em ensaios laboratoriais os demais foram calculados por relação massa/volume, como pode ser observado na TABELA 3.

TABELA 3 - Parâmetros físicos calculados do solo

\begin{tabular}{c|c|c}
\hline Parâmetros & Referência & Resultado \\
\hline Porosidade $(\mathrm{n})$ & ASTM $(1995)$ & $43 \%$ \\
\hline Índice de Vazios (e) & Carvalho (1997) & 0,75 \\
\hline Volume de Poros (VP) & ASTM (1995) & $2,73 \mathrm{~L}$ \\
\hline Grau de Saturação (Sr) & Carvalho (1997) & $37,9 \%$ \\
\hline Massa Específica do Solo $(\rho)$ & Nogueira $(1995)$ & $1,713 \mathrm{~g} / \mathrm{cm}^{3}$ \\
\hline Massa Específica Seca $\left(\rho_{\mathrm{d}}\right)$ & Nogueira $(1995)$ & $1,530 \mathrm{~g} / \mathrm{cm}^{3}$ \\
\hline
\end{tabular}




\subsection{1. ÍNDICES FÍSICOS}

\subsubsection{MASSA ESPECÍFICA DOS SÓLIDOS}

A determinação da massa específica dos sólidos do solo $\left(\rho_{\mathrm{s}}\right)$ foi realizado no Laboratório de Solos do Departamento de Geotecnia da Escola de Engenharia de São Carlos - USP, conforme a Norma MB-32 (ABNT, 1984 a). O resultado da massa específica encontrada foi de $2,68 \mathrm{~g} / \mathrm{cm}^{3}$.

\subsubsection{ANÁLISE GRANULOMÉTRICA}

A análise realizada na amostra de solo coletado foi baseado na Norma MB-32 (ABNT,1984 a) e executado em duas etapas, uma por peneiramento (areia e pedregulho) e outra por sedimentação (silte e argila).

Para o processo de peneiramento utilizou-se massa total inicial de $124 \mathrm{~g}$ contendo $8,3 \%$ de umidade onde foram utilizadas conjunto de conforme NBR 5734 (ABNT,1980). O solo foi colocado na peneira de maior abertura e o conjunto foi levado para vibrar por 20 minutos. Após esse procedimento, foi determinada a massa de sólidos retidos em cada peneira e no prato.

O processo realizado paralelamente complementa a análise granulométrica, determinando a parcela de solo fino, isto é, a porcentagem de argila e silte presentes no solo. Na amostra em condições naturais colocou-se água destilada e como dispersante químico, o Hexametanofosfato de Sódio $\left(\mathrm{Na}_{3} \mathrm{PO}_{4}\right)_{\mathfrak{n}}$, formando uma solução de $0,125 \mathrm{~L}$, a qual foi levada para um dispersor. Após a dispersão, a suspensão foi transferida para uma proveta graduada, acrescentando-se água destilada até atingir o volume de $1 \mathrm{~L}$. Após a mistura, foi colocada rapidamente a proveta em repouso e deu-se início a contagem de tempo. As leituras foram realizadas nos tempos 0,$5 ; 1 ; 2 ; 4 ; 8 ; 15 ; 30 ; 60$; 120; 240 e 480 minutos. Introduziu-se o densímetro e o termômetro na suspensão para cada leitura, sendo que no intervalo de leitura, estes foram colocados em outra proveta com água destilada.

Os valores obtidos para a granulometria foram: argila $=0 \%$; silte $=6 \%$, areia fina $=34 \%$, areia média $=41 \%$ e areia grossa $=19 \%$ (FIGURA 7$)$. 
PENERAS ABNT ( NBR 5734/80)

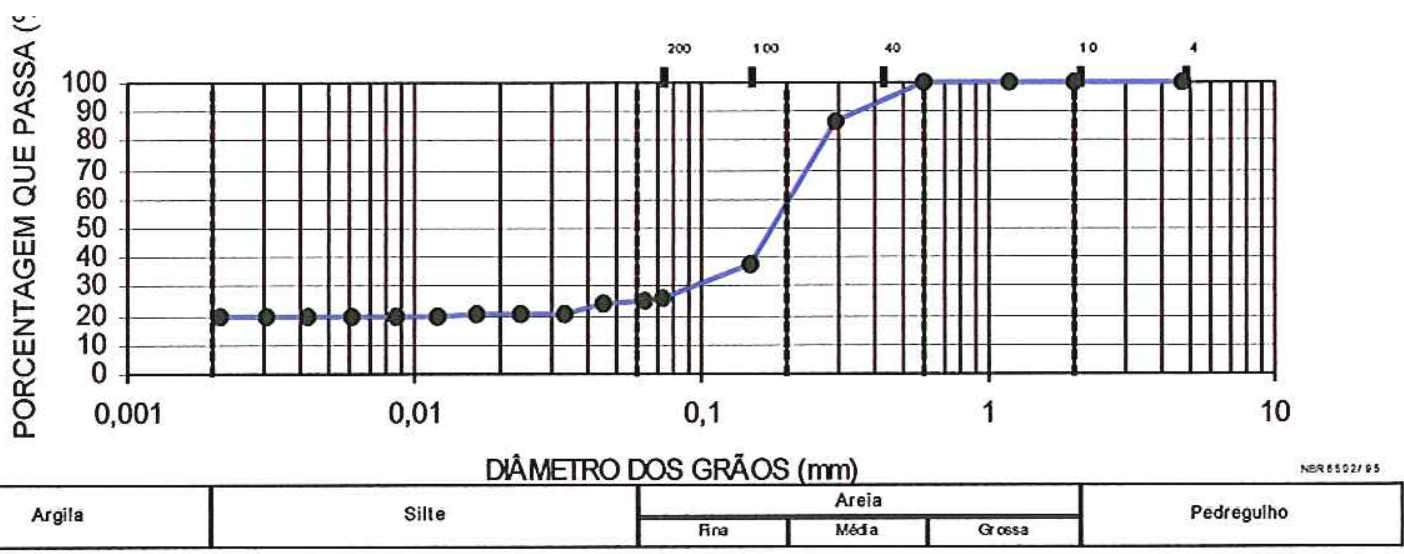

FIGURA 7 - Curva Granulométrica do solo amostrado

De acordo com a distribuição das partículas no solo, este recebe uma designação, sendo classificado em determinada classe textural. Utilizando-se o Diagrama Triangular para classificação do solo em que nesse triangulo eqüilátero dividido, encontram-se porcentagens de areia, silte e argila do solo e, em função da região $\mathrm{em}$ que se encontra o ponto de convergência dos valores de ocorrência, lê-se a denominação do solo. O triângulo eqüilátero mostrado na FIGURA 8 permite, de acordo com a distribuição granulométrica, classificar o solo coletado no Aterro Sanitário de São Carlos, como Areia.

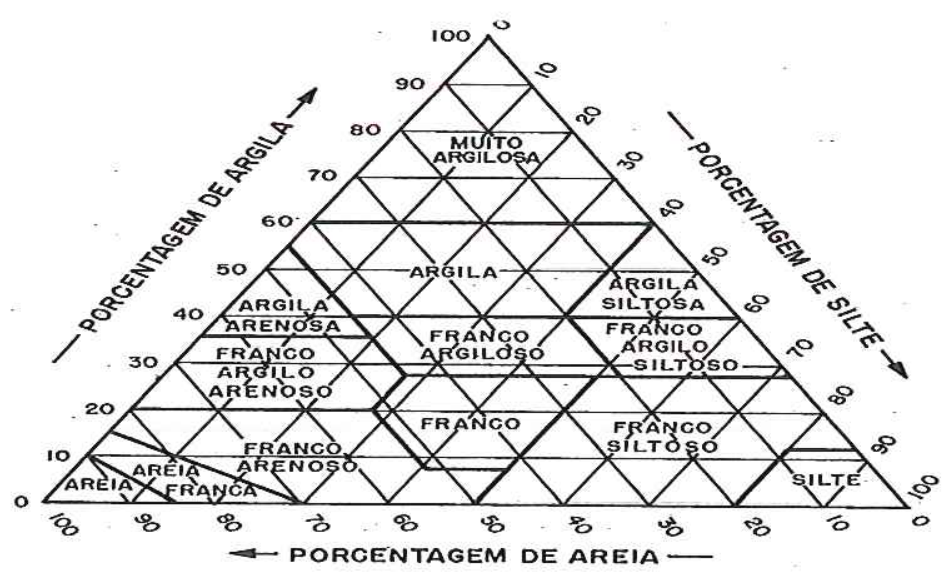

FIGURA 8 - Diagrama Triangular para definição da classe textural do solo FONTE: GUIMARÃES (2002)

Mas deve-se levar em consideração que os diagramas triangulares não levam em conta a forma da curva granulométrica (importante nos solos grossos) e a plasticidade (importante nos solos finos), em que uma boa classificação para a Mecânica dos Solos

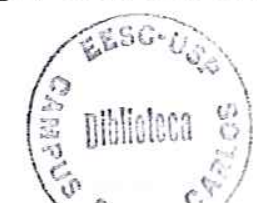


deve considerar esses dois parâmetros citados. Assim, de acordo com o Sistema Unificado de Classificação dos Solos (SUCS), que se baseia nos limites de liquidez, de plasticidade e da granulometria, o solo amostrado pode ser classificado como "Grosso", pois possui mais de $50 \%$ em peso dos grãos retidos na peneira de $0,075 \mathrm{~mm}$ e designado pela letra S (areia) (FORTES,2004).

\subsection{CARACTERIZAÇão QUíMICA DO SOLO}

A investigação de propriedades químicas do solo é relevante para interpretação dos resultados obtidos em ensaios de colunas. Os parâmetros caracterizam o solo e auxiliam na compreensão de possíveis processos que possam ocorrer durante o contato com as soluções contaminantes. Com este objetivo, o solo em estudo foi caracterizado quimicamente. A TABELA 4 apresenta as propriedades químicas do solo estudado.

TABELA 4 - Propriedades químicas do solo estudado

\begin{tabular}{l|c}
\hline \multicolumn{1}{c|}{ PROPRIEDADES } & SOLO \\
\hline CTC $(\mathrm{meq} / 100 \mathrm{~g})-$ Azul de Metileno & 2,58 \\
\hline Superfície Específica $\left(\mathrm{m}^{2} / \mathrm{g}\right)$ & 20,25 \\
\hline $\mathrm{pH}$ do solo $\left(\mathrm{H}_{2} \mathrm{O}\right)(1: 2,5$ solo: solução) & 4,77 \\
\hline $\mathrm{pH}$ do solo $(\mathrm{KCl})(1: 2,5$ solo: solução) & 4,32 \\
\hline$\triangle \mathrm{pH}\left(\mathrm{pH} \mathrm{KCl}-\mathrm{pH} \mathrm{H}_{2} \mathrm{O}\right)$ & $-0,45$ \\
\hline Condutividade Elétrica $(\mathrm{mS} / \mathrm{cm})$ & 6,50 \\
\hline
\end{tabular}

\subsubsection{DETERMINAÇÃO DA CAPACIDADE DE TROCA CATIÔNICA (CTC) E SUPERFÍCIE ESPECÍFICA (SE)}

Para obtenção dos valores de CTC e SE do solo foi utilizado o Método de Adsorção por Azul de Metileno, descrito por PEJON (1992). O azul de metileno $\left(\mathrm{C}_{16} \mathrm{H}_{18} \mathrm{~N}_{3} \mathrm{SCl}, 3 \mathrm{H}_{2} \mathrm{O}\right.$ - Cloridato de metilamina) é um corante catiônico orgânico que substitui cátions adsorvidos no solo. A quantidade de corante suficiente para ocupar todos os sítios de adsorção mede diretamente a CTC e SE. Nesta metodologia utilizouse 2 a $4 \mathrm{~g}$ de solo (massa úmida) que passa pela peneira de $2 \mathrm{~mm}$ de abertura de malha.

Calculou-se a superfície específica através da equação (1):

$$
S E=\frac{3,67 \cdot V}{M}
$$


Onde:
$\mathrm{SE}$ - Superfície Específica $\left(\mathrm{m}^{2} / \mathrm{g}\right)$
V - Volume da solução de Azul de Metileno gasto (mL)
$\mathrm{M}$ - Massa do solo seco (g)

A Capacidade de Troca de Cátions (CTC) expressa em meq/100g foi obtida a partir da seguinte equação (2) (PEJON,1992):

$$
C T C=\frac{V \cdot C \cdot 100}{M}
$$

Onde:

V - Volume da solução de Azul de Metileno gasto (mL)

C - Concentração da solução de azul de metileno gasta (Normalidade)

M - Massa do solo seco (g)

Maiores detalhes sobre estes ensaios poderão ser encontrados na referência citada. Os valores de CTC e da SE do solo coletado estão apresentadas na TABELA 5.

TABELA 5 - Valores da CTC e SE do solo estudado, conforme a massa da amostra e o volume de azul de metileno empregado

\begin{tabular}{c|c|c|c|c}
\hline \multirow{2}{*}{ Amostra } & $\begin{array}{c}\text { Massa da } \\
\text { Amostra (g) }\end{array}$ & $\begin{array}{c}\text { Volume de } \\
\text { Azul de } \\
\text { Metileno (mL) }\end{array}$ & $\begin{array}{c}\text { Superfície } \\
\text { Específica } \\
\left(\mathbf{m}^{\mathbf{2}} / \mathbf{g}\right)\end{array}$ & $\begin{array}{c}\text { CTC } \\
(\mathbf{m e q} / \mathbf{1 0 0 g})\end{array}$ \\
\cline { 2 - 5 } & 0,9966 & 5,5 & 20,25 & 2,58 \\
\hline
\end{tabular}

\subsubsection{DETERMINAÇÃO DO $\Delta \mathrm{pH}, \mathrm{pH}_{0}, \Delta \mathrm{pH}_{\mathrm{H} 2 \mathrm{O}} \mathrm{E} \Delta \mathrm{pH}_{\mathrm{KCl}}$ DO SOLO}

$\mathrm{O} \Delta \mathrm{pH}$ permite reconhecer rapidamente a predominância ou não de carga variável no solo. Para isso, basta medir o pH de suspensão do solo em água e em $\mathrm{KCl}$ (1N). Com esses valores calculou-se o parâmetro $\Delta \mathrm{pH}$, defínido como a equação 3 :

$$
\Delta p H=p H(K C l)-p H\left(H_{2} O\right)
$$

$\mathrm{O}$ sinal e a magnitude do $\Delta \mathrm{pH}$ correspondem ao sinal e à magnitude da carga superficial. Se o $\Delta \mathrm{pH}$ for zero, tiver valor negativo pequeno ou valor positivo, há indicação de que o solo seja dominado com carga variável. Se o $\Delta \mathrm{pH}$ for fracamente 
negativo, nada se pode afirmar sobre a carga (variável ou permanente). Obteve-se o valor de pH0 para o solo amostrado utilizando-se a equação 4 a seguir:

$$
p H_{0}=2 p H(K C l)-p H\left(H_{2} O\right)
$$

$\mathrm{O}$ pH do solo foi medido segundo procedimentos de CAMARGO et al. (1996). Nesta metodologia, uma razão 1:2,5 de volume solo/solução foi utilizada, sendo que nos ensaios efetuados a massa foi considerada, mas o volume não. A justificativa decorre da dificuldade de obtenção de volumes precisos para solos em condição úmida. As quantidades foram de $10 \mathrm{~g}$ de solo para $25 \mathrm{~g}$ de líquido (água ou $\mathrm{KCl}$ ) com a mensuração sendo efetuada em eletrodo de vidro combinado.

Por meio da TABELA 6 é possível observar que o valor obtido de $\triangle \mathrm{pH}$ para o solo coletado foi de $-0,45$, indicando um suave predomínio de cargas negativas. Assim os resultados de $\mathrm{pH}_{\mathrm{H} 2 \mathrm{O}}, \mathrm{pH}_{\mathrm{KCl}}, \mathrm{pH}_{0}$ também são apresentados.

TABELA 6 - Valores de $\Delta \mathrm{pH}_{\mathrm{H} 2 \mathrm{O}}, \Delta \mathrm{pH}_{\mathrm{KCl}}, \Delta \mathrm{pH}$ e $\mathrm{pH}_{0}$ para o solo analisado

\begin{tabular}{c|c|c|c|c}
\hline \multirow{2}{*}{ Amostra } & $\mathbf{p H}_{\mathbf{H} 2 \mathrm{O}}$ & $\mathbf{p H}_{\mathbf{K C l}}$ & $\Delta \mathbf{p H}$ & $\mathbf{p H}_{\mathbf{0}}$ \\
\cline { 2 - 5 } & 4,77 & 4,32 & $-0,45$ & 3,87 \\
\hline
\end{tabular}

\subsubsection{DETERMINAÇÃO DA CONDUTIVIDADE ELÉTRICA}

A condutividade elétrica do solo foi medida segundo procedimentos de CAMARGO et al. (1996). Nesta metodologia uma razão 1:1 de massa solo/ volume solução foi utilizada. As quantidades foram de $50 \mathrm{~g}$ de solo para $50 \mathrm{~g}$ de água destilada, sendo que a mistura foi agitada de 15 em 15 minutos durante duas horas. Após esse período de agitação, o sobrenadante foi filtrado para posterior mensuração, que foi efetuada utilizando-se condutivímetro.

Para amostra analisada a condutividade elétrica do solo foi de $6,5 \mathrm{mS} / \mathrm{cm}$.

\subsubsection{DETERMINAÇÃO DOS TEORES DE METAIS PESADOS}

O solo coletado foi submetido à análise quanto aos teores de metais pesados trocáveis $(\mathrm{Zn}, \mathrm{Pb}, \mathrm{Cd}, \mathrm{Ni}, \mathrm{Cr}, \mathrm{Fe}, \mathrm{Mn}$ e $\mathrm{Cu})$ por Espectrometria de Absorção Atômica (EAA), em que as amostras foram submetidas ao Método de Digestão Acida com $\mathrm{HCl}$ 
0,1M (CETESB, 1994) no Laboratório de Saneamento do Departamento de Hidráulica e Saneamento da Escola de Engenharia de São Carlos - USP.

A concentração de metal das amostras antes do solo ser colocado nas colunas para o teste de percolação, permitiu a determinação de quantidades de metais presentes no solo amostrado em condições naturais, ou seja, em condições de campo.

Os valores da concentração inicial de metais no solo podem ser vistos na TABELA 7.

TABELA 7 - Concentração de metais pesados no solo coletado, em condições naturais (condições de campo)

\begin{tabular}{c|c|c|c|c|c|c|c|c}
\hline \multirow{2}{*}{$\begin{array}{c}\text { Metais } \\
(\mathbf{m g} / \mathbf{K g})\end{array}$} & $\mathbf{Z n}$ & $\mathbf{P b}$ & $\mathbf{C d}$ & $\mathbf{N i}$ & $\mathbf{F e}$ & $\mathbf{M n}$ & $\mathbf{C u}$ & $\mathbf{C r}$ \\
\cline { 2 - 8 } & 32,0 & $<0,1$ & $<0,3$ & $<0,4$ & 5500,0 & 29,0 & 50,0 & $<0,25$ \\
\hline
\end{tabular}

\subsection{PROCEDIMENTOS EXPERIMENTAIS}

\subsubsection{MONTAGEM DAS COLUNAS}

O experimento foi desenvolvido no Laboratório do Núcleo de Estudo e Pesquisa em Resíduos Sólidos (NEPER) do Centro de Recursos Hídricos e Ecologia Aplicada (CRHEA) pertencente ao Departamento de Hidráulica e Saneamento da Escola de Engenharia de São Carlos - USP.

Para execução do teste de percolação foram montadas colunas de acrílico e preenchidas com o solo coletado do Aterro Sanitário de São Carlos.

As colunas foram divididas em duas partes:

- uma inferior, de maior dimensão ( $9 \mathrm{~cm}$ de diâmetro e $100 \mathrm{~cm}$ de altura) onde o solo fícou armazenado e foi percolado com o chorume;

- e uma superior, de menor dimensão ( $9 \mathrm{~cm}$ de diâmetro e $24 \mathrm{~cm}$ de altura), onde procedeu-se o armazenamento e posterior coleta do chorume percolado na parte inferior.

Estas duas partes foram conectadas por registros de aço inox e acrílico, acopladas com mangueiras de silicone, fechadas com pinças, para a coleta do efluente, como apresentado na FIGURA 9. 


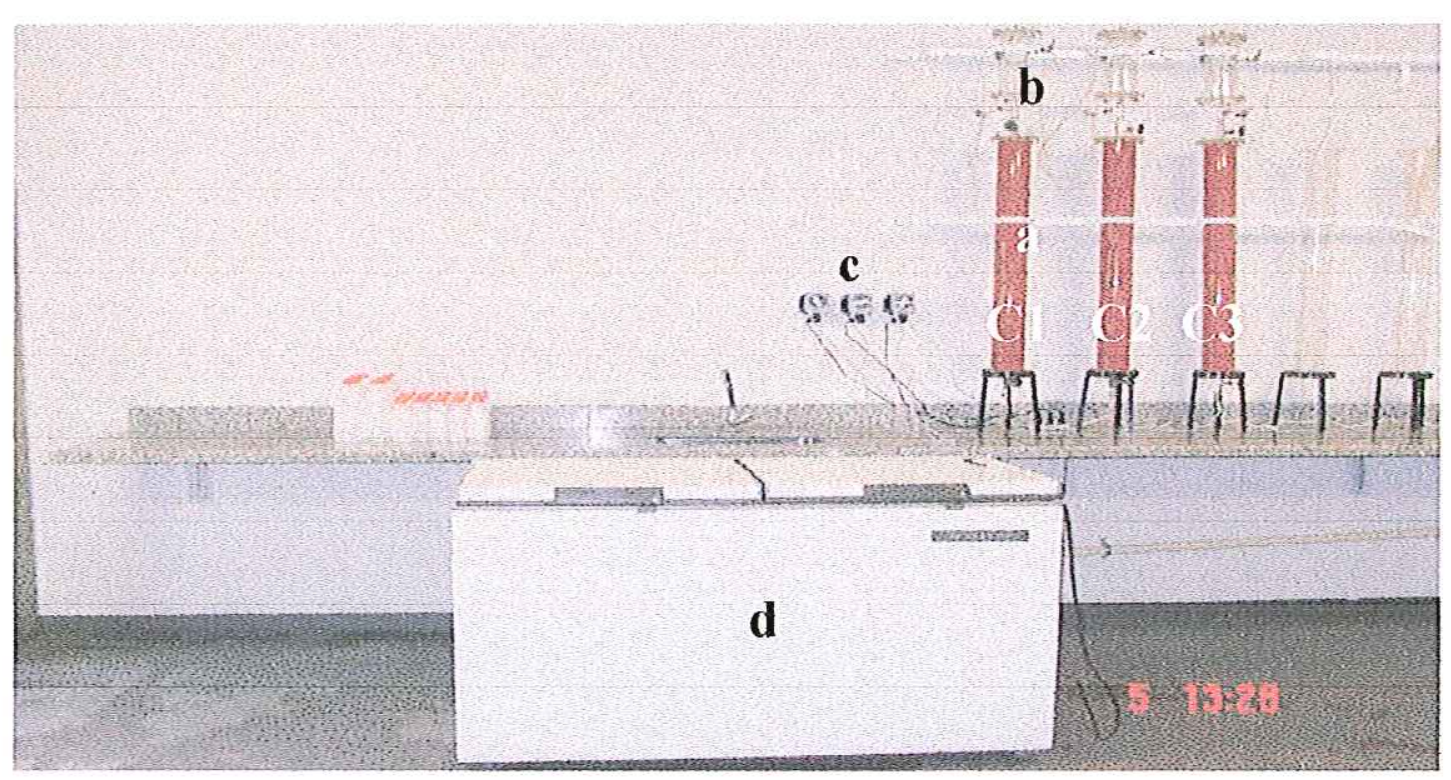

FIGURA 9 - Partes estruturais das colunas para o teste de percolação

a: Parte inferior - Armazenamento de solo;

b: Parte superior - Armazenamento de chorume percolante;

c: Bombas peristálticas;

d: Refrigerador para armazenamento do chorume;

C1: Coluna 1 percolada com chorume;

C2: Coluna 2 percolada com chorume e

C3: Coluna 3 percolada com água.

O experimento foi realizado tendo uma repetição onde foi testado um único tipo de chorume, percolado em um tipo de solo. Foram montadas três colunas, sendo duas colunas percoladas com chorume e uma coluna percolada somente com água. Portanto, esta coluna serviu de comparação com as demais para verificar a capacidade de retenção de contaminantes presentes no chorume pelo solo.

Para o bombeamento dos líquidos percolados foram utilizadas três bombas peristálticas, as quais foram calibradas para um fluxo diário de $250 \mathrm{~mL}$ (FIGURA 9), operadas em fluxo ascendente para prevenir canalização, ou seja, evitar a formação de caminhos preferenciais de percolação e permitir que todo o solo presente na coluna entrasse em contato com o líquido percolado (KJELDSEN, 1984). Assim, durante a montagem das colunas foi colocado uma tela fina de $2 \mu \mathrm{m}$ de abertura, abaixo de cada coluna, para assegurar um fluxo unidimensional e prevenir o entupimento da saída (TUXEN et al., 2000). 
Procurando minimizar a decomposição do chorume que alimentou as colunas durante todo o experimento, este foi armazenado em refrigerador em temperatura controlada (aproximadamente $4^{\circ} \mathrm{C}$ ), o qual foi perfurado para a passagem das mangueiras de silicone alimentadoras das colunas (FIGURA 9).

\subsubsection{SATURAÇÃO DAS COLUNAS DE SOLO}

Após montadas e preenchidas com solo e antes de entrar em contato com as soluções contaminantes, as colunas foram saturadas com água, coletada do poço localizado no Centro de Recursos Hídricos e Ecologia a Aplicada (CRHEA) isenta de contaminantes para propiciar o equilíbrio entre a água e o solo, prevenindo interferências de reações geoquímicas, sem relevância para o estudo (TUXEN et al., 2000).

A percolação com água foi mantida por fluxo ascendente com auxílio de bombas peristálticas até que cada coluna fosse equilibrada com 1 volume de poros (ou de vazios) (1VP) para posteriormente ser percolada com chorume. Essa fase foi concluída ao ser alcançadas as condições de saturação do solo nas colunas, ou seja, quando os poros vazios de cada coluna estavam preenchidos com água.

A água coletada foi analisada e os valores dos parâmetros analisados antes do início da percolação nas três colunas são apresentados na TABELA 8. 
TABELA 8 - Composição da água coletada do poço de uso regular do CRHEA antes do início da percolação nas colunas experimentais

\begin{tabular}{|c|c|}
\hline Parâmetros & Água do poço \\
\hline Turbidez (uT) & 0,31 \\
\hline $\mathrm{pH}$ & 7,7 \\
\hline $\mathrm{Eh}(\mathrm{mV})$ & 260 \\
\hline $\mathrm{CE}(\mu \mathrm{S} / \mathrm{cm})$ & 59,1 \\
\hline Dureza $\left(\mathrm{mg} \mathrm{CaCO}_{3} / \mathrm{L}\right)$ & - \\
\hline Alcalinidade $\left(\mathrm{mg} \mathrm{CaCO}_{3} / \mathrm{L}\right)$ & 35,2 \\
\hline$\dot{\mathrm{COT}}(\mathrm{mg} / \mathrm{L})$ & - \\
\hline $\mathrm{OD}(\mathrm{mg} / \mathrm{L})$ & 7,6 \\
\hline DQO (mg/L) & 18,7 \\
\hline $\mathrm{DBO}(\mathrm{mg} / \mathrm{L})$ & - \\
\hline Fosfato $(\mathrm{mg} / \mathrm{L})$ & - \\
\hline Sulfato $(\mathrm{mg} / \mathrm{L})$ & - \\
\hline $\mathrm{Cl}(\mathrm{mg} / \mathrm{L})$ & 0,4 \\
\hline Nitrato $(\mathrm{mg} / \mathrm{L})$ & - \\
\hline Nitrito $(\mathrm{mg} / \mathrm{L})$ & - \\
\hline $\mathrm{Na}(\mathrm{mg} / \mathrm{L})$ & 1,1 \\
\hline $\mathrm{K}(\mathrm{mg} / \mathrm{L})$ & 3,8 \\
\hline $\mathrm{Ca}(\mathrm{mg} / \mathrm{L})$ & 10,09 \\
\hline $\mathrm{Mg}(\mathrm{mg} / \mathrm{L})$ & 0,4 \\
\hline $\mathrm{Fe}(\mathrm{mg} / \mathrm{L})$ & - \\
\hline $\mathrm{Mn}(\mathrm{mg} / \mathrm{L})$ & - \\
\hline $\mathrm{Zn}(\mathrm{mg} / \mathrm{L})$ & - \\
\hline $\mathrm{Pb}(\mathrm{mg} / \mathrm{L})$ & - \\
\hline $\mathrm{Cu}(\mathrm{mg} / \mathrm{L})$ & - \\
\hline $\mathrm{Cd}(\mathrm{mg} / \mathrm{L})$ & - \\
\hline $\mathrm{Cr}(\mathrm{mg} / \mathrm{L})$ & - \\
\hline $\mathrm{Ni}(\mathrm{mg} / \mathrm{L})$ & - \\
\hline Sólidos Totais (mg/L) & - \\
\hline Sólidos Totais Fixos (mg/L) & - \\
\hline Sólidos Totais Voláteis $(\mathrm{mg} / \mathrm{L})$ & - \\
\hline
\end{tabular}

- Não detectado

\subsubsection{COLETA DO CHORUME}

O chorume foi coletado em caixa de acúmulo localizada no aterro sanitário de São Carlos, conforme pode ser observado na FIGURA 10. O chorume coletado é direcionado para as lagoas de estabilização presentes e destas lagoas o chorume é recirculado sobre o aterro sanitário. Foi coletado uma amostra no local para caracterização química deste chorume antes de se iniciar o teste de percolação em colunas. 

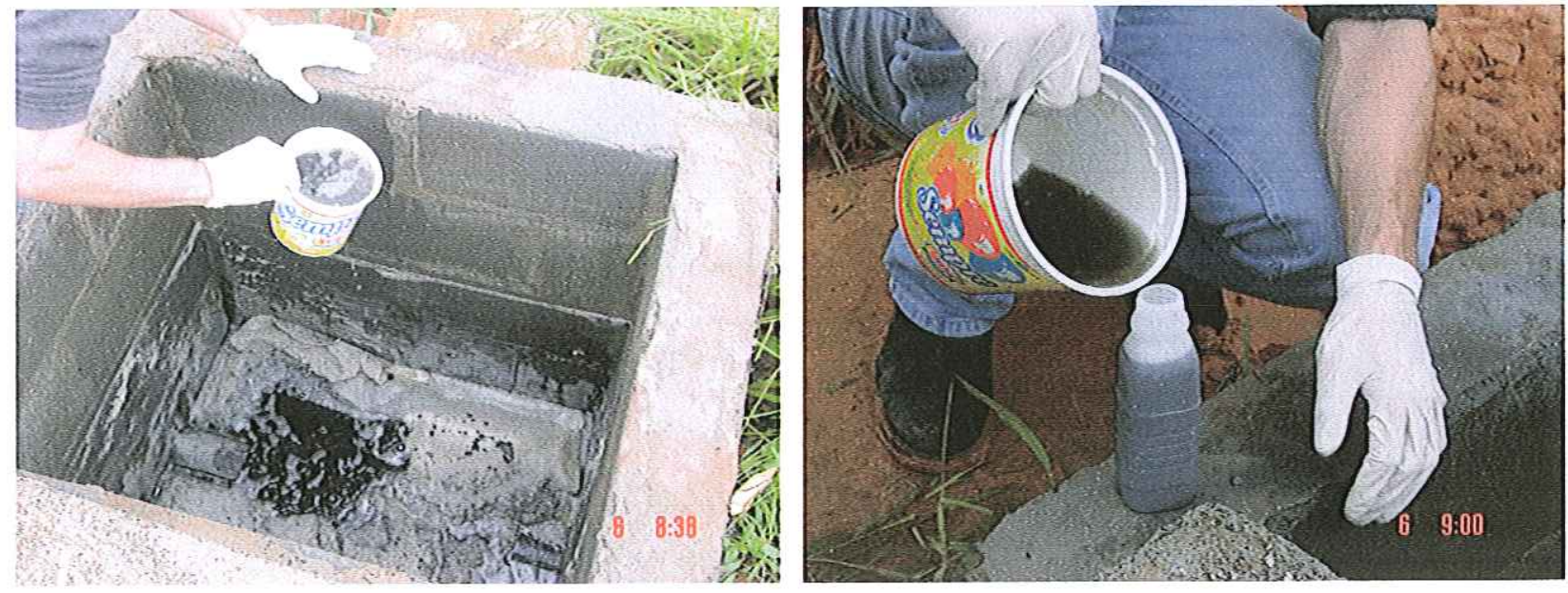

FIGURA 10 - Local de coleta do chorume para percolação nas colunas: Caixa de acúmulo do Aterro Sanitário de São Carlos (03/01/2005)
FIGURA 11 - Amostra de chorume analisado antes da percolação nas colunas (03/01/2005)

\subsubsection{PREPARO DO CHORUME PARA INÍCIO DO TESTE DE PERCOLAÇÃO}

O chorume coletado e acondicionado em galões de $32 \mathrm{~L}$ foi encaminhado para $\mathrm{o}$ laboratório do NEPER no CRHEA - SHS - EESC/USP e colocado em refrigerador para manter suas características próximas das originais e evitar sua degradação.

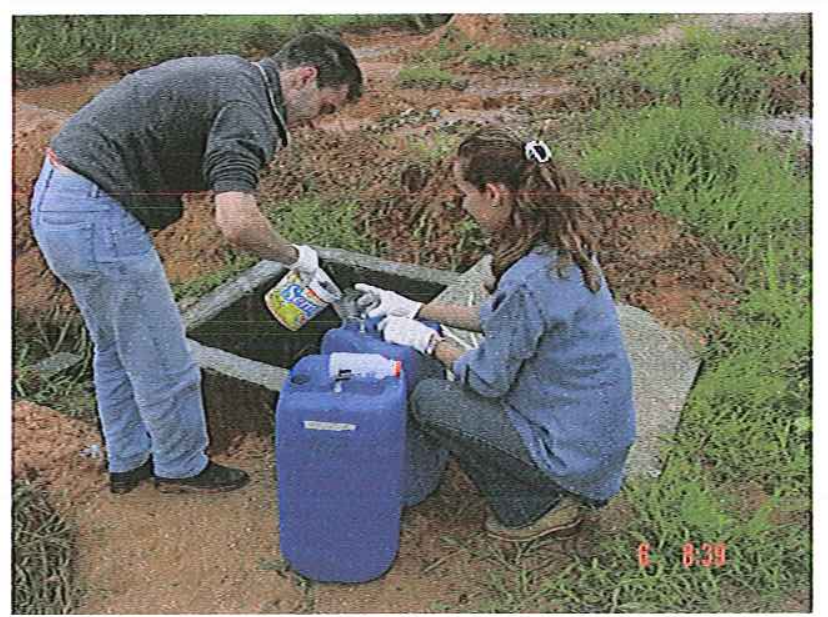

FIGURA 12 - Acondicionamento do chorume coletado (03/01/2005)

No laboratório, o chorume foi acidificado para reduzir o $\mathrm{pH}$, evitando a precipitação dos metais pesados no início da percolação do chorume no solo e promovendo aumento da mobilidade destes na coluna de solo, conforme YONG et al, (2001). 
Foram aplicadas soluções enriquecidas com Cromo, Chumbo, Cobre, Manganês, Cádmio $(5 \mathrm{mg} / \mathrm{L})$ e Zinco $(10 \mathrm{mg} / \mathrm{L})$ para acompanhar o comportamento destes contaminantes (CHRISTENSEN et al., 1989; JENSEN et al., 1999; THORTON et al., 2000; YONG et al., 2001).

A percolação do chorume foi iniciada pelas bombas peristálticas, com fluxo de $250 \mathrm{~mL} /$ dia, as quais operaram a uma pressão contínua, assegurando o fluxo dos líquidos percolados e mantendo condições de saturação durante o experimento. Esse fluxo de percolado condicionado pelas bombas peristálticas representa, juntamente com as dimensões das colunas de acrílico e as características físicas do solo, que a velocidade de percolação nas colunas foi de $4 \mathrm{~cm} / \mathrm{dia}$, o que representa um tempo de permanência de 10 dias.

É importante ressaltar que a velocidade de percolação deve ser baixa o suficiente para que o equilíbrio das reações seja atingido, por outro lado, velocidades muito baixas não são convenientes por levar o ensaio a se estender indefinidamente. Dessa forma, torna-se inviável a reprodução em laboratório da velocidade de percolação de campo. Então, por esses fatores a velocidade de percolação foi ajustada para um fluxo diário de $250 \mathrm{~mL} /$ dia, diminuindo o tempo de realizações do ensaio.

TABELA 9 - Caracterização do chorume percolado antes e depois da acidificação e enriquecimento com soluções salinas de $\mathrm{Cr}, \mathrm{Pb}, \mathrm{Cu}, \mathrm{Mn}, \mathrm{Zn}$ e $\mathrm{Cd}$

\begin{tabular}{l|c|c}
\hline Parâmetros & ANTES & DEPOIS \\
\hline $\mathrm{pH}$ & 4,82 & 2,08 \\
\hline Eh $(\mathrm{mV})$ & 380,00 & 428 \\
\hline $\mathrm{CE}(\mathrm{mS} / \mathrm{cm})$ & 15,84 & 19,27 \\
\hline Turbidez & 844,00 & 647,00 \\
\hline $\mathrm{DQO}(\mathrm{mg} / \mathrm{L})$ & $10.800,00$ & $11.040,00$ \\
\hline Cloreto $(\mathrm{mg} / \mathrm{L})$ & $1.090,00$ & $1.190,00$ \\
\hline $\mathrm{K}(\mathrm{mg} / \mathrm{L})$ & 810,00 & $1.170,00$ \\
\hline $\mathrm{Na}(\mathrm{mg} / \mathrm{L})$ & 860,00 & $1.190,00$ \\
\hline $\mathrm{Cd}(\mathrm{mg} / \mathrm{L})$ & $<0,0006$ & 5,30 \\
\hline $\mathrm{Cr}(\mathrm{mg} / \mathrm{L}$ & $<0,005$ & 9,10 \\
\hline $\mathrm{Cu}(\mathrm{mg} / \mathrm{L})$ & 0,40 & 1,25 \\
\hline $\mathrm{Fe}(\mathrm{mg} / \mathrm{L})$ & 65,00 & 85,60 \\
\hline $\mathrm{Mn}(\mathrm{mg} / \mathrm{L})$ & 5,09 & 19,00 \\
\hline $\mathrm{Ni}(\mathrm{mg} / \mathrm{L})$ & 0,15 & 0,20 \\
\hline $\mathrm{Zn}(\mathrm{mg} / \mathrm{L})$ & 1,52 & 3,67 \\
\hline $\mathrm{Pb}(\mathrm{mg} / \mathrm{L})$ & 0,13 & 5,34 \\
\hline
\end{tabular}




\subsubsection{COLETA DE AMOSTRAS EFLUENTES}

Amostras do efluente que percolou pelas colunas de solo foram coletadas a cada 0,2 VP percolado. Foi assim determinado para acompanhar num curto período de tempo o que estava ocorrendo com os estes efluentes que percolavam no solo, ou seja, minimizando a freqüência de amostragem o acompanhamento de possíveis alterações físico-químicas que estivessem ocorrendo seria registrado.

Para o fim da percolação do chorume nas colunas, procurou-se acompanhar estudo desenvolvido por CASSIANO (2004), que verificou a percolação de chorume em material sólido do Aqüífero Guarani. O material sólido utilizado no estudo de CASSIANO (2004) e o utilizado neste, têm características físicas e químicas muito semelhantes. Portanto, como foi observado no estudo da percolação de chorume- em material sólido do Aqüífero Guarani, que os parâmetros dos efluentes coletados começavam a fícar constantes a partir de 4,0 VP, foi definido então o tempo de percolação deste estudo. Assim a coleta foi cessada quando atingiu 5,0 VP percolados.

As amostras efluentes retiradas foram preservadas com ácido nítrico concentrado $\left(\mathrm{HNO}_{3}\right)$, cerca de $1 \mathrm{~mol} / \mathrm{L}$ para determinação de metais (APHA et al. $\left.3112 \mathrm{E}, 1998\right)$ e analisadas no Laboratório de Saneamento do Departamento de Hidráulica e Saneamento da EESC/USP quanto aos parâmetros de $\mathrm{pH}$, Temperatura $\left({ }^{\circ} \mathrm{C}\right)$, Turbidez (UNT ou uT), Condutividade elétrica $\left(\mathrm{mS} . \mathrm{cm}^{-1}\right)$. O Eh $(\mathrm{mV})$ foi obtido com auxílio de eletrodo de platina, combinado a um eletrodo de referência, o qual estava presente no próprio Laboratório do NEPER, onde estava montado o experimento, para que esta medidas fossem feitas no local e no momento de coleta.

Os métodos e as variáveis físico-químicas são apresentadas no QUADRO 5.

QUADRO 5 - Variáveis físicas e químicas a serem analisadas com os métodos utilizados e respectivas referências

\begin{tabular}{l|c|l}
\hline \multicolumn{1}{c|}{ Parâmetros } & Método & \multicolumn{1}{c}{ Referência } \\
\hline DQO (mg/L) & Colorimétrico & $\begin{array}{l}\text { APHA et al. (1998) - 5220 } \\
\text { D }\end{array}$ \\
\hline Cloreto (mg/L) & Espectrométrico & $\begin{array}{l}\text { APHA et al. (1998) - 4110 } \\
\text { B }\end{array}$ \\
\hline $\begin{array}{l}\text { Metais pesados }(\mathrm{Ca}, \mathrm{K}, \mathrm{Mg}, \mathrm{Na}, \\
\mathrm{Cd}, \mathrm{Cr}, \mathrm{Cu}, \mathrm{Fe}, \mathrm{Mn}, \mathrm{Ni}, \mathrm{Zn} \mathrm{e} \mathrm{Pb})\end{array}$ & $\begin{array}{c}\text { Espectrometria de Emissão } \\
\text { Atômica }\end{array}$ & $\begin{array}{l}\text { APHA et al. (1998) - 3120 } \\
\text { B }\end{array}$ \\
\hline
\end{tabular}




\subsubsection{DESMONTAGEM DAS COLUNAS EXPERIMENTAIS}

Ao término do experimento, os reservatórios de coletas foram drenados e as colunas foram desmontadas.

Cada coluna apresentava um comprimento total de $100 \mathrm{~cm}$, com todo o seu volume ocupado com solo, ou seja, cerca de $10,9 \mathrm{Kg}$ solo/coluna.

De cada coluna, foram retiradas amostras na forma de fatias das partes inferiores das colunas, que estavam preenchidas com solo, com $15 \mathrm{~cm}$ aproximadamente, espaçadas igualmente ao longo das colunas.

Essas amostras foram submetidas a análises de metais em aparelho de Espectrometria de Absorção Atômica, após digestão ácida com $\mathrm{HCl}(0,1 \mathrm{M})$ conforme CETESB (1994), a fim de gerar os perfis de retenção de metais após 5,0 VP.

Portanto, os resultados obtidos foram analisados através de gráficos relacionando-se os parâmetros: Condutividade elétrica, Potencial Hidrogeniônico, Potencial Redox, Turbidez, Demanda Química de Oxigênio e Concentração relativa dos contaminantes presentes no chorume em função do número de volume de poros vazios percolados (VP) e, também o perfil de retenção de metais nas colunas de solo. 


\section{RESULTADOS E DISCUSSÃO}

Algumas considerações sobre os resultados serão apresentadas objetivando a comparação dos valores em relação aos encontrados na literatura. É interessante salientar que as condições de experimento aqui executadas foram únicas e também que o solo em estudo é diferente da maioria dos materiais reportados na literatura, dificultando sobremaneira as comparações.

\subsection{CARACTERIZAÇÃO DO SOLO}

O solo utilizado para os testes de percolação possui propriedades físico-químicas desfavoráveis a sua utilização como base de aterros sanitários. Ao se analisar a TABELA 10 e comparar esses valores com aqueles obtidos nos ensaios de caracterização, constata-se o inadequado enquadramento deste solo para suportar tal estrutura.

TABELA 10 - Comparação dos dados obtidos na caracterização do solo versus aspectos utilizados na seleção de áreas para localização de aterros sanitários

\begin{tabular}{l|c|c|c|c}
\hline \multicolumn{1}{c|}{ Atributos } & Adequado & $\begin{array}{c}\text { Com } \\
\text { restrição }\end{array}$ & Inadequado & $\begin{array}{c}\text { Obtido nos } \\
\text { ensaios }\end{array}$ \\
\hline $\mathrm{CTC}(\mathrm{meq} / \mathrm{l00 \textrm {g }})$ & $>20$ & $20-5$ & $<5$ & 2,58 \\
\hline $\mathrm{pH}\left(\mathrm{H}_{2} \mathrm{O}\right)$ & $\geq 4$ & $>5$ & $<4 \mathrm{e}>7$ & 4,77 \\
\hline $\begin{array}{l}\text { Salinidade ou } \\
\text { Condutividade } \\
\text { Elétrica }(\mathrm{mS} / \mathrm{cm})\end{array}$ & $<16$ & $>16$ & Muito alto & 6,5 \\
\hline Textura & $<25 \%$ areia & $10-40 \%$ areia & $>40 \%$ areia & $94 \%$ de areia \\
\hline
\end{tabular}

Fonte: GUIMARÃES, 2000 (modificado)

A CTC é um parâmetro importante na retenção dos poluentes orgânicos e outros íons menos móveis, indicando a capacidade de retenção do solo. Refere-se à maior ou menor capacidade que o solo possui em trocar cátions para neutralizar as cargas negativas, sendo função da textura, mineralogia e $\mathrm{pH}$ do solo. Ela pode ser alterada se 
houver variação do $\mathrm{pH}$ e, à medida que o material vai sendo saturado pela passagem de contaminante, seu valor vai diminuindo.

De acordo com os resultados da análise das propriedades químicas, o solo apresentou baixa CTC e SE, indicando baixa capacidade de reter metais pesados via troca catiônica, apresentando-se menos favorável à retenção de poluentes. OLIVEIRA et al. (2001) observaram efeitos prejudiciais da presença de metais provenientes da destinação final de resíduos sólidos, em solos com baixa CTC (menor que $5 \mathrm{meq} / 100 \mathrm{~g}$ ) e baixo conteúdo de argila, particularmente em solos com $\mathrm{pH}$ em torno de 4,0 (determinado em água), condições análogas ao estudo aqui desenvolvido.

Para tal, são indicados solos argilosos, capazes de atenuar o transporte de contaminantes devido às suas propriedades químicas, como elevada CTC e SE, além de alta capacidade tamponante (YONG et al., 1992). O uso de solos argilosos como impermeabilizante ou barreiras de atenuação está se tornando um material de escolha para composição de liners, que além do baixo custo, pode retardar a taxa de percolação e permitir a atenuação química dos contaminantes através de diversos processos de sorção (YONG et al, 2001).

O pH do solo também é um fator que deve ser considerado na capacidade de retenção de contaminantes, por isso foi determinado com o objetivo de monitorar o comportamento destes elementos em função do grau de acidez ou de alcalinidade do solo. A variação do $\mathrm{pH}$ facilita a ocorrência de várias reações químicas que provocam a retenção e/ou liberação desses contaminantes. Este parâmetro foi medido em solução de $\mathrm{KCl}$ e em água e, com esses valores obtidos foi calculado o $\Delta \mathrm{pH}$ (distribuição de cargas elétricas no solo). Foi obtido valor negativo para este parâmetro, o que pode indicar que o solo é mais favorável à adsorção de poluentes, possui maior capacidade de retenção de cátions e menor capacidade de retenção de ânions.

DEMATTÊ (1989) argumenta que valores de $\Delta \mathrm{pH}$ positivos indicam o predomínio de cargas positivas no sistema solo/água. Tal fato se deve à grande quantidade de óxidos e hidróxidos de $\mathrm{Fe}$ e $\mathrm{Al}$ presentes no solo. Mas para valores de $\Delta \mathrm{pH}$ negativos, nada se pode afirmar sobre a carga existente no solo, se é variável ou permanente, apenas que se está diante de uma partícula de solo com grande densidade de carga negativa (CASANOVA, 1989). Desta forma, pode-se observar que o valor de $\Delta \mathrm{pH}$ obtido para o solo é de $-0,45$, indicando um suave predomínio de cargas negativas. 
$\mathrm{O}$ valor de $\mathrm{pH}$ do solo amostrado $(\mathrm{pH}=4,77)$ é relativamente ácido, permitindo que os contaminantes presentes em percolados de aterro (principalmente os metais pesados) estejam mais disponíveis, devido à diminuição da adsorção destes nos colóides do solo e, também, por conferir menor estabilidade aos complexos que se formam entre metais e a fração húmica do solo (ALLOWAY, 1995). O processo de retenção depende do $\mathrm{pH}$ da solução do solo e variações nesse atributo interferem no equilíbrio sorção/dessorção de contaminantes, mostrando influência fundamental no destino dos contaminantes inorgânicos (THORTON et al., 2000).

A salinidade do solo é um parâmetro que representa a presença de sais no solo, sendo expresso pela condutividade elétrica do extrato obtido do conjunto solo mais água. Em um solo com alta salinidade, devido à característica hidrófila dos sais, a passagem do percolado pode romper a estrutura do solo, o que aumenta o poder contaminante do percolado e pode formar novos compostos ainda mais tóxicos (GUIMARÃES, 2000). Assim, o solo amostrado tem $6,5 \mathrm{mS} / \mathrm{cm}$ de condutividade elétrica, valor considerado adequado para ser empregado em áreas de disposição final de resíduos sólidos.

A textura do solo define a capacidade do substrato de se deixar atravessar pelos efluentes e exerce influência sobre a capacidade de carga do solo. A textura argiloarenosa apresenta boa capacidade de depuração e de carga, apresentando baixa permeabilidade. Por outro lado, textura muito arenosa possui alta permeabilidade, o que permite a passagem de contaminantes (GUIMARÃES, 2000), como o observado aqui neste estudo.

O solo amostrado, segundo a Análise Granulométrica, mostrou-se extremamente arenoso (94\% de areia, $6 \%$ de silte e $0 \%$ de argila), o que o torna inadequado para a utilização em áreas de aterros sanitários, pois nesse material o efluente percola facilmente. De acordo com SHARMA \& LEWIS (1994) e ROWE et al. (1995) este solo não apresenta características apropriadas que satisfaçam as exigências técnicas para o uso como liner em base de aterro.

Observa-se, então, pelos valores de CTC, SE, pH e pela classe textural arenosa, que este solo possui deficiente capacidade tamponante (ou de retenção de contaminantes), o que lhe confere fraca capacidade de imobilização dos contaminantes inorgânicos (THORTON et al., 2000).

Os teores de metais pesados do solo foram determinados, a fim de se mensurar a concentração destes elementos, antes de colocar o solo nas colunas experimentais para 
início do teste de percolação. Os valores obtidos foram comparados com valores orientadores para solos do Estado de São Paulo, conforme TABELA 11.

TABELA 11 - Comparação dos valores orientadores para solos do Estado de São Paulo versus solo do aterro sanitário de São Carlos.

\begin{tabular}{c|c|c|c|c|c|c}
\hline \multicolumn{7}{c}{ VOLORES ORIENTADORES* } \\
\hline \multirow{2}{*}{ Substância } & \multirow{2}{*}{ Referência } & \multirow{2}{*}{ Alerta } & \multicolumn{3}{c}{ Referência } & Solo \\
\cline { 4 - 7 } & & & Agrícola/APMax $^{1}$ & Residencial & Industrial & Aterro \\
\hline Cd & $<0,5$ & 3,0 & 10,0 & 15,0 & 40,0 & $<0,3$ \\
\hline $\mathbf{P b}$ & 17,0 & 100,0 & 200,0 & 350,0 & 1200,0 & $<0,1$ \\
\hline $\mathbf{C u}$ & 35,0 & 60,0 & 100,0 & 500,0 & 700,0 & 50,0 \\
\hline $\mathbf{C r}$ & 40,0 & 75,0 & 300,0 & 700,0 & 1000,0 & $<0,25$ \\
\hline $\mathbf{F e}$ & - & - & - & - & - & 5500,0 \\
\hline $\mathbf{M n}$ & - & - & - & - & - & 29,0 \\
\hline $\mathbf{N i}$ & 13,0 & 30,0 & 50,0 & 200,0 & 300,0 & $<0,4$ \\
\hline $\mathbf{Z n}$ & 60,0 & 300,0 & 500,0 & 1000,0 & 1500,0 & 32,0 \\
\hline
\end{tabular}

1: APMax - Área de Proteção Máxima

*CETESB (2001a)

Considerando a questão da proteção da qualidade do solo, a adoção de valores orientadores, denominados valores de referência de qualidade, de alerta e de intervenção, é necessária para subsidiar decisões e para o controle da poluição nas áreas já contaminadas e/ou suspeitas de contaminação. Esses valores foram estabelecidos com base em dados nacionais e na avaliação de risco à saúde humana (CETESB, 2001a).

O solo amostrado apresentou teor de metais pesados abaixo dos valores de referência, com exceção do $\mathrm{Cu}$, o qual apresentou concentração abaixo do valor de alerta. Na lista de valores de referência de qualidade não constam valores para Fe e Mn, pois estes metais são encontrados naturalmente nos solos tropicais em altas concentrações (CETESB, 2001a), conforme valores encontrados para o solo do aterro.

Portanto, o solo da área de estudo possui baixo nível de concentração de metais e não é considerado contaminando, portanto, não necessita de maiores investigações ou intervenções.

Desta forma, testes de percolação em colunas foram utilizados neste estudo para avaliar a capacidade do solo amostrado em atenuar o transporte de contaminantes, especialmente os metais pesados, apesar de suas características desfavoráveis aos processos de retenção e atenuação dos contaminantes. 


\subsection{PARÂMETROS FÍSICO- QUÍMICOS}

Os parâmetros físico-químicos foram avaliados com base nas curvas de variação da Condutividade Elétrica (CE), Potencial Hidrogeniônico $(\mathrm{pH})$, Potencial Elétrico ou Redox (Eh), Turbidez e Demanda Química de Oxigênio (DQO), em função do número de volume de poros (ou de vazios) percolados (VP).

As curvas para cada ensaio estão representadas nas FIGURAS 13 à 17 e será observado nestas figuras que até aproximadamente 0,2 VP os parâmetros analisados apresentam comportamentos peculiares e que podem ser explicados pela diluição da água de saturação aplicados no solo das colunas antes que este entrasse em contato com o chorume. Pode-se dizer que nas primeiras coletas o chorume estava diluído com a água e, somente a partir de 1,0 VP obteve-se somente chorume nos efluentes coletados.

\section{Condutividade Elétrica}

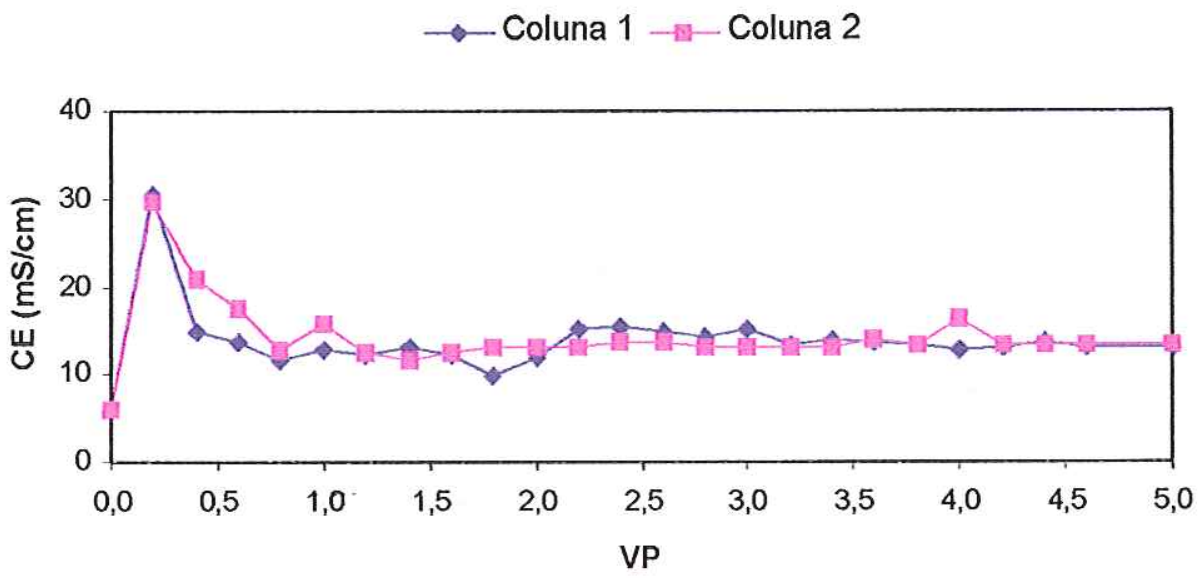

FIGURA 13 - Curvas de variação da Condutividade Elétrica (CE) em função do número de Vazios Percolados (VP) para as Colunas 1 e 2

A condutividade elétrica (CE) oferece informações sobre a concentração salina das soluções, ou seja, é um indicador da capacidade de uma solução em conduzir corrente elétrica, sendo dependente do número, valência, mobilidade e tipos de íons presentes e, ainda, da temperatura (MENEZES, 1995)

Está correlacionada com a concentração de minerais dissolvidos ou de sólidos totais dissolvidos na amostra e é diretamente proporcional à concentração das soluções eletrolíticas. Em águas ácidas ( $\mathrm{pH}$ menor 5) os íons $\mathrm{H}^{+}$tornam-se responsáveis pelos valores de condutividade (MENEZES, 1995). 
Assim, durante o experimento foi possível acompanhar as variações das concentrações eletrolíticas nas soluções efluentes das colunas 1 e 2, percoladas com chorume.

Os valores de $\mathrm{CE}$ encontrados durante as análises dos efluentes, variaram de 9,86 a $30,0 \mathrm{mS} / \mathrm{cm}$. São valores altos e típicos da elevada concentração de contaminantes em líquidos percolados de aterros.

Análises de chorume em aterros dos EUA (ROSS, 1990) revelaram condutividade variando conforme o tempo de estabilização dos resíduos, ou seja, ela diminuiu de 19,02 mS/cm (em 5 meses de aterramento) para 12,5 mS/cm (em 42 meses de aterramento). Em aterros experimentais estudados por SCHALCH (1992), nos quais foram depositados lixo do município de São Carlos, a condutividade dos percolados variou de $24,6 \mathrm{mS} / \mathrm{cm}$ a $43,43 \mathrm{mS} / \mathrm{cm}$ no aterro 1 e de 24,0 a $38,42 \mathrm{mS} / \mathrm{cm}$ no aterro 2 .

Na FIGURA 13 observa-se uma brusca elevação do valor de CE entre 0,0 e 0,2 VP percolados. Após $0,2 \mathrm{VP}$ os valores começaram a diminuir até tornarem-se constantes. Esse aumento significativo do valor da $\mathrm{CE}$ pode ter ocorrido devido ao enriquecimento do chorume com soluções de metais no início do experimento, com o objetivo de acompanhar a mobilidade destes elementos no solo. Assim, verificou-se uma leve tendência do solo em reduzir a concentração dos eletrólitos presentes no chorume.

\section{Potencial Hidrogeniônico}
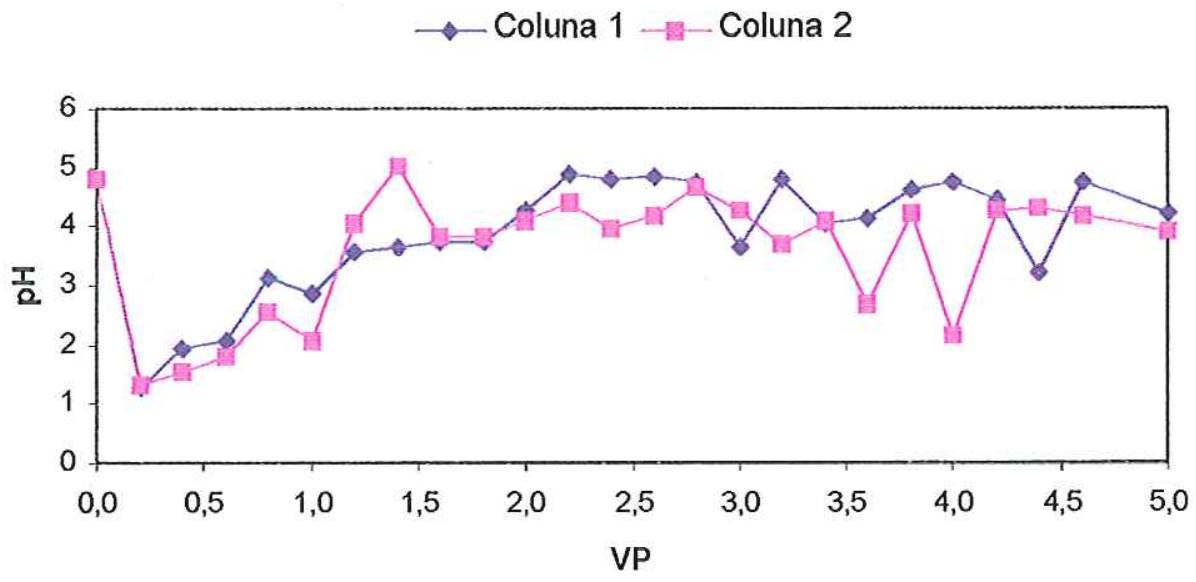

FIGURA 14 - Curvas de variação do Potencial Hidrogeniônico $(\mathrm{pH})$ em função do número de Vazios Percolados (VP) para as Colunas 1e 2 
Para entendimento do comportamento das curvas de variação de $\mathbf{p H}$, apresentadas na FIGURA 14, em função do Volume de Poros percolados com chorume, vale detalhar o procedimento experimental.

O chorume coletado na caixa de acúmulo do aterro sanitário de São Carlos possuía um valor de $\mathrm{pH}$ de 4,82, o que lhe confere uma característica ácida, indicando ausência de substâncias tamponantes e predominância de ácido carbônico. POHLAND 5 \& GOLD (1986) apud SCHALCH (1992) mostram, em estudo realizado em aterros experimentais, a tendência do comportamento do $\mathrm{pH}$ durante as fases de estabilização da matéria orgânica. Com base nesse estudo, pode-se dizer que o chorume coletado para o experimento de teste de percolação em colunas estava em fase de estabilização anaeróbia ácida, caracterizada pela produção de ácidos orgânicos em $\mathrm{pH}$ menor que 6,0. Portanto, quando coletado o chorume estava na fase 3 de estabilização, ou fase de formação de ácido, em que predomina a formação de ácidos voláteis totais com decréscimo nos valores do $\mathrm{pH}$, elevação da concentração da DQO e aumento da mobilidade das espécies iônicas.

Observa-se queda acentuada do valor de $\mathrm{pH}$ em 0,2 VP e, de acordo com o volume de poros percolados com chorume, esse valor retomou o de coleta. Essa queda ocorreu devido ao processo de acidificação em laboratório antes do início da percolação, a qual foi feita com o objetivo de reduzir o $\mathrm{pH}$, a fím de evitar a precipitação dos metais pesados no início do contato do chorume no solo e, aumentar a mobilidade destes nas colunas, já que o pH afeta a capacidade de complexação de metais em água e pode determinar quando estará precipitado ou dissolvido (MENEZES, 1995).

As curvas de variação de pH versus VP (FIGURA 14) permitem constatar uma tendência geral progressiva de redução do $\mathrm{pH}$ durante a percolação com chorume. Isto pode acontecer devido ao efeito de substituição do próton $\mathrm{H}^{+}$, ligado a hidroxilas expostas nas superfícies das partículas do solo por cátions em solução (como, por exemplo, $\mathrm{K}^{+} \mathrm{e} \mathrm{Cu}^{++}$), tornando-o com característica mais ácida.

Comportamento análogo foi obtido por HAMADA et al. (2004) em testes de percolação onde verificaram durante os ensaios de colunas alimentadas com chorume alcalino, a acidificação dos efluentes. Esta pode ter ocorrido devido à solubilização dos minerais presentes no solo, que também era de característica ácida, ou devido à perda de

\footnotetext{
${ }^{5}$ POHLAND e GOULD (1986) Co-disposal of municipal refuse and industrial waste sludge in landfills. Water Science Techrology, v.18, n.12, p.177-192.
} 
bases do solo, arrastadas pela água e pelo chorume durante a infiltração. Mas por outro lado, segundo AGNELLI (1997), a característica ácida do solo é o fator relevante para a acidificação do efluente.

\section{Potencial Elétrico}

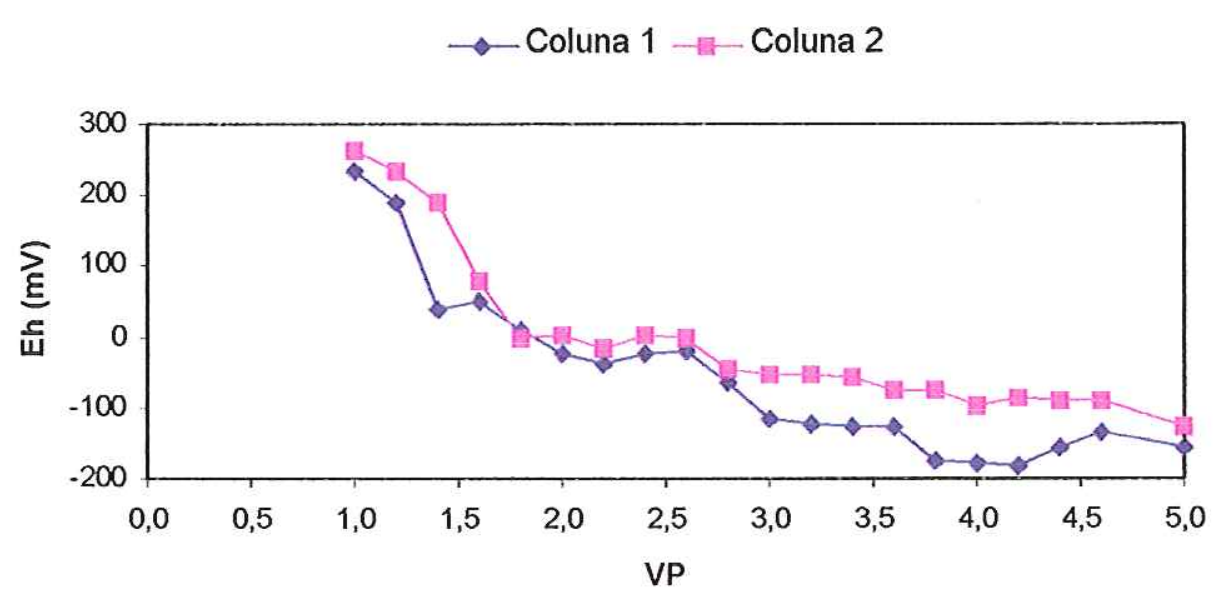

FIGURA 15 - Curva de variação do Potencial Elétrico (Eh) em função do número de Vazios Percolados (VP) para as Colunas 1 e 2

O Potencial Elétrico (Redox) ou de Oxidação-Redução (Eh) é um parâmetro físico-químico que atua em conjunto com o pH, os quais são indicativos das condições de oxidação-redução e ácido-base do sistema e são controladores da mobilidade de alguns elementos no ambiente, dentre eles a maioria dos metais pesados (SCHALCH,1992).

Nas reações com transferência de elétrons, a capacidade do redutor em doar elétrons é devido ao potencial padrão de redução $\mathrm{E}_{025^{\circ} \mathrm{C}}$, visto que sistemas redox com o $\mathrm{E}_{025^{\circ} \mathrm{C}}$ relativamente negativo tendem a doar elétrons para o sistema redox com $\mathrm{E}_{025^{\circ} \mathrm{C}}$ positivo (SCHALCH, 1992).

Os valores do parâmetro Eh foram medidos a partir de 1,0 VP percolados, devido à falta de equipamento para leitura no Laboratório onde estava instalado o experimento.

Observa-se na FIGURA 15, que no início da percolação os efluentes coletados nas duas colunas apresentavam valores de Eh positivos, indicando que no ambiente ocorriam reações doadoras de elétrons, ou seja, reações de oxidação. A partir de 2,0 VP percolados, o Eh dos efluentes coletados diminuíram, ficando abaixo de zero, apresentando valores negativos, o que indica ocorrência de reações aceptoras de elétrons 
(ou reações de redução). Portanto, o fluxo do percolado pelas colunas de solo passou de condições oxidantes para redutoras.

De acordo com estudo do levantamento de dados da variação do comportamento do potencial de oxidação-redução para as diversas fases de estabilização da matéria orgânica desenvolvido por POHLAND \& GOULD (1986) apud SCHALCH (1992) sugere que as fases estão associadas às faixas de Eh. Então, a variação deste parâmetro, observada durante o experimento de percolação (de $234 \mathrm{mV}$ à $-155 \mathrm{mV}$ ), indica que o percolado realmente apresentava-se na fase de formação de ácidos, que tem uma variação de 80 à $-240 \mathrm{mV}$ (diminuição esperada para redução de oxigênio).

Por meio das FIGURAS 14 e 15 foi possível comparar os parâmetros pH e Eh, ocorridos ao longo da percolação nas colunas experimentais e constatar uma tendência oposta dos dois parâmetros, ou seja, o crescimento de um dos índices provocou a redução do outro e vice-versa, sugerindo que um está correlacionado ao outro. Essa constatação é confirmada pelos estudos de BOURG \& LOCH (1995), os quais afirmam que os processos redox podem induzir forte acidificação ou alcalinização do solo e de outros sistemas aquáticos. Desta forma, componentes redutores induzem a elevação da alcalinidade e componentes oxidantes tendem a induzir a acidez (diminuir o $\mathrm{pH}$ ) conforme observado.

\section{Turbidez}

$\rightarrow$ Coluna $1-$ Coluna 2

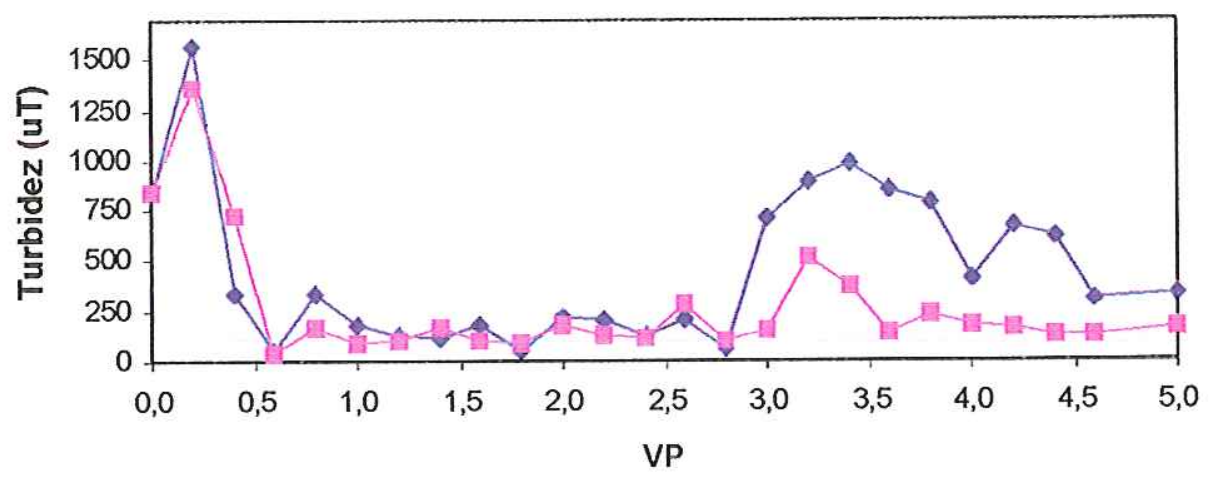

FIGURA 16 - Curva de variação da Turbidez em função do número de Vazios Percolados (VP) para as Colunas 1 e 2.

A Turbidez é um parâmetro que representa o grau de interferência com a passagem da luz através da água, conferindo aparência turva à mesma. Para medida de comparação, sabe-se que uma ligeira nebulosidade pode ser notada quando seu valor é 
próximo de 10 uT (unidade de turbidez). Quando a Turbidez é igual a 500 uT é porque a água está praticamente opaca (ESTEVES, 1988).

Assim, o chorume amostrado na caixa de coleta apresentava 855 uT, ou seja, completamente opaco e de cor escura. Este chorume foi levado para o Laboratório do NEPER, acidificado e enriquecido com metais para o início da percolação. Em 0,2 VP percolados, observou-se um pico de Turbidez no efluente coletado e depois uma queda, a qual permaneceu praticamente constante até 3,0 VP percolados.

Esses baixos e constantes valores de Turbidez apresentados até 3,0 VP percolados para ambas colunas representam a capacidade filtrante do solo, ou seja, o chorume entrou na coluna de solo com coloração escura e com Turbidez elevada e foi coletado com coloração clara e com Turbidez baixa (se comparada com a Turbidez de entrada).

A partir de 3,0 VP, os efluentes coletados apresentaram alterações significativas na cor, acarretando um aumento no valor da Turbidez. Essa variação fornece indícios que ocorreu saturação do meio percolante, reduzindo a capacidade depurativa do solo, ou seja, a capacidade filtrante diminuiu.

\section{Demanda Química de Oxigênio}

$\rightarrow$ Coluna $1-$ Coluna 2

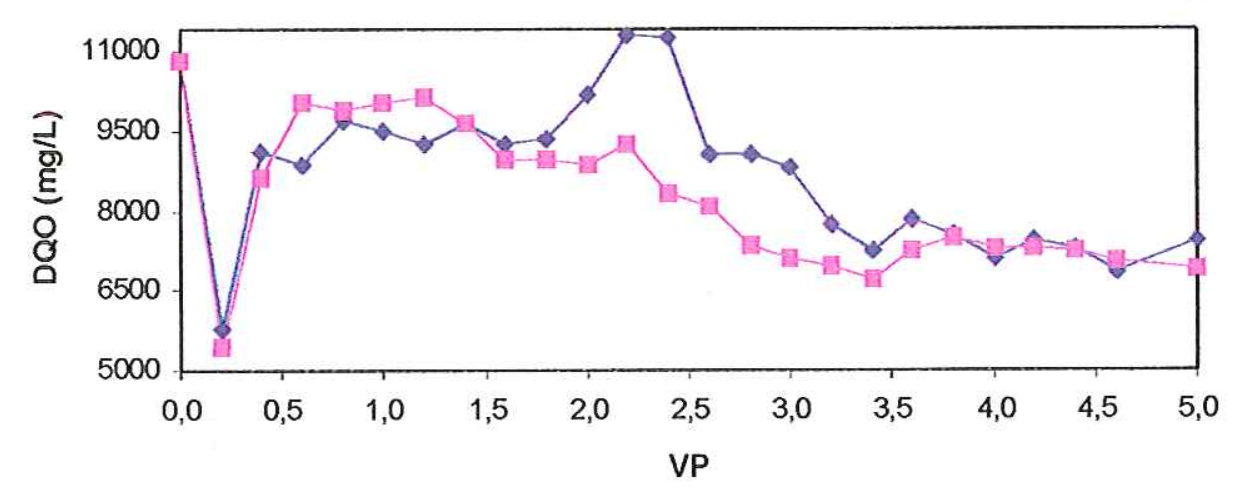

FIGURA 17 - Curva de variação da Demanda Química de Oxigênio (DQO) em função do número de Vazios Percolados (VP) para as Colunas 1 e 2.

A Demanda Química de Oxigênio (DQO) é utilizada para determinar o equivalente de oxigênio na matéria orgânica contida em uma amostra capaz de sofrer oxidação por um forte agente oxidante. A DQO indica a quantidade de oxigênio que é consumida quimicamente por diversos compostos orgânicos, sem a intervenção de 
microorganismos, fornecendo, em termos de oxigênio consumido, a quantidade de matéria oxidável presente (MENEZES,1995).

SCHALCH (1984), a partir de análises em laboratório de amostras de lixo urbano, mostrou que a DQO do chorume produzido era inicialmente $35.250 \mathrm{mg} / \mathrm{L}$ e decorridos sete meses esse valor passou para $6.972 \mathrm{mg} / \mathrm{L}$.

Comportamento análogo foi observado neste estudo. Nas colunas percoladas com chorume o material coletado apresentou DQO elevada de $10.800 \mathrm{mg} / \mathrm{L}$. No início da percolação, ou seja, após 0,2 VP percolados, foi constatado decaimento da DQO pela metade. Esse fato pode ter ocorrido devido ao processo de diluição, lembrando-se que, antes de iniciar a percolação com chorume, as colunas foram percoladas com água insenta de contaminantes. Portanto, nessa primeira coleta do efluente, o chorume pode ter sido diluído pela água ainda presente nos poros do solo.

Na coluna 1, em 0,4 VP percolado, foi observado que a DQO quase retomou seus altos valores iniciais e permaneceu aproximadamente constante com valores elevados até 2,2 VP percolados. A partir deste ponto, constatou-se que o valor da DQO superou o seu valor inicial e, logo depois, retornou a valores mais baixos.

Na coluna 2, observou-se uma tendência de diminuição da DQO durante os 5,0 VP percolados.

Sendo a DQO um parâmetro químico que expressa o teor de matéria orgânica, verifica-se que o solo presente nas colunas reteve a matéria orgânica presente no chorume, visto que o chorume entrou nas colunas com DQO (carga orgânica) elevada. Na coleta dos efluentes a cada $0,2 \mathrm{VP}$, essa carga orgânica foi reduzida, cerca de $40 \%$ da carga orgânica presente no chorume afluente foi minimizada pelas colunas de solo.

De forma geral, foi observado nessas curvas de variações dos parâmetros $\mathrm{CE}$, $\mathrm{pH}$, Eh, Turbidez e DQO versus volume de poros percolados com chorume, que o solo funcionou como filtro, com capacidade para depurar e imobilizar impurezas nele depositadas, apesar de suas características físico-químicas não favoráveis à atenuação dos contaminantes. Também foi constatado que essa capacidade é limitada, podendo ocorrer alteração da qualidade do solo devido ao efeito acumulativo da deposição dos poluentes ocorrida ao longo da percolação com o chorume.

Portanto, os resultados encontrados neste estudo mostram que, apesar das características físicas e químicas desfavoráveis, o solo amostrado tem potencial para uso em base de aterros sanitários de pequeno porte, pois reteve a carga orgânica do chorume. Resultados semelhantes foram encontrados por HAMADA et al. (2004), os 
quais avaliaram o transporte de líquido e atenuação da carga orgânica do chorume de aterro sanitário em solo arenoso fino com diferentes graus de compactação. Contudo, devido à textura arenosa, o solo apresentou baixa capacidade de retenção de contaminantes, característica que pode ser melhorada através da mistura de uma certa quantidade de argila, conforme indicado pelos autores.

\subsection{CURVAS CARACTERÍSTICAS DE TRANSPORTE DE CONTAMINANTES}

Foram traçadas Curvas Características de Transporte de concentrações relativas $(\mathrm{Ce} / \mathrm{Co})$ dos contaminantes presentes no chorume percolante $-\mathrm{Zn}, \mathrm{Pb}, \mathrm{Cd}, \mathrm{Fe}, \mathrm{Mn}, \mathrm{Cu}$, $\mathrm{Na}, \mathrm{K}, \mathrm{Ni}$ e $\mathrm{Cl}$ - versus o número de poros (ou vazios) percolados (VP).

Não foi possível traçar a curva de concentração relativa para $\mathrm{Cr}$, pois o teor deste metal apresentou-se abaixo do limite de detecção do Espectrofotômetro de Absorção Atômica $(<0,005 \mathrm{mg} / \mathrm{L})$ em todas as amostras efluentes coletadas. Possivelmente, este metal ficou retido na coluna de solo, conforme apresentado no item 4.4.

Para melhor visualização dos resultados, as curvas características de transporte para cada coluna foram divididas em grupos, originando quatro FIGURAS as quais foram confrontadas com a evolução do $\mathrm{pH}$. Cada uma dessas figuras compara a coluna 1 com a 2. No primeiro grupo estão $\mathrm{Pb}, \mathrm{Cd}$ e $\mathrm{Fe}, \mathrm{Zn}$ e $\mathrm{Mn}$ versus $\mathrm{pH}$ versus Volume de Poros percolados. No segundo grupo estão $\mathrm{Na}, \mathrm{K}, \mathrm{Cl}$, $\mathrm{Ni}$ e $\mathrm{Cu}$ versus $\mathrm{pH}$ versus Volume de Poros percolados, como será apresentado nas FIGURAS 18 à 21. E para a avaliação do comportamento destes elementos em relação às variáveis físico-químicas, as curvas foram confrontadas com a evolução do $\mathrm{pH}$.

$\mathrm{O}$ pH é um parâmetro que determina a forma com que o metal se apresentará e, também, os processos atuantes sobre esses elementos, determinando sua retenção ou dessorção no meio. Assim, valores elevados de $\mathrm{pH}$ faz com que predominem mecanismos de precipitação, portanto eles ficam menos disponíveis, o que resulta em maior sorção dos mesmos por materiais sólidos presentes no solo, formando precipitados (YONG et al., 2001).

Com base na FIGURA 14, verifica-se a variação do $\mathrm{pH}$ durante os 5,0 VP percolados na faixa de 1,30 a 5,0, enquadrando-se na faixa ácida. Portanto, os mecanismos de precipitação tornaram-se menos importantes e, provavelmente, o processo de troca de cátions (dessorção e dissolução) predominou nesse sistema. Os 
metais pesados apresentaram maior mobilidade permitindo que a adsorção nas partículas de solo fosse efetivamente reduzida devido à competição nos locais de troca com o $\mathrm{H}^{+}$(YONG et al., 2001).

A solubilidade dos metais pesados foi influenciada pelo $\mathrm{pH}$ do percolado, o qual variou durante o processo de percolação, mas manteve-se ácido e permitiu que os metais permanecessem em solução, ou seja, não precipitassem (OLIVEIRA et al., 2004). Assim, a interação dos mecanismos de controle da capacidade de assimilação dos metais pelo solo envolveu a combinação de mobilização por lixiviação, particularmente devido às condições ácidas e, certa imobilização a partir de 3,0 VP devido à formação de condições redutoras.

Observa-se que, de acordo com as curvas características de transporte para $\mathrm{Pb}$, $\mathrm{Cd}, \mathrm{Fe}, \mathrm{Mn}$ e Ni, para ambas colunas após 5,0 VP percolados com chorume enriquecido com metais, as amostras efluentes não apresentaram a metade de sua concentração na solução afluente. Ou seja, os metais nos efluentes amostrados a cada 0,2 VP apresentaram-se com concentração muito baixa, o que sugere uma possível retenção destes elementos no solo.

Já nas curvas características de transporte para $\mathrm{Cu}, \mathrm{Na}, \mathrm{K}$ e $\mathrm{Cl}$ para ambas colunas após 5,0 VP percolados com chorume enriquecido com metais, as amostras efluentes apresentaram concentração mais elevada. Ou seja, a presença destes metais nos efluentes amostrados a cada 0,2 VP foi mais significativa, sugerindo que estes elementos são pouco reativos.

No início da percolação do chorume, observou-se certa liberação dos metais presentes, os quais foram encontrados nos efluentes amostrados, sendo que esta liberação é dependente do $\mathrm{pH}$ e, pode ser atribuída à acidificação e à dessorção produzida pelas reações de hidrólise (THORTON et al., 2000).

A presença de vários ligantes no chorume interferiu na adsorção dos metais pesados no solo devido à formação de complexos solúveis, o que dificulta a previsão do transporte de contaminantes. Estudo realizado por YONG et al. (1992) mostra que entre os ligantes que podem formar complexos com os metais pesados encontram-se os íons $\mathrm{Cl}^{-}, \mathrm{SO}_{4}{ }^{-}$e orgânicos. $\mathrm{O} \mathrm{Cd}$, por exemplo, não é adsorvido pelo solo se estiver na forma de $\mathrm{CdCl}_{3}{ }^{-}$e $\mathrm{CdCl}_{4}{ }^{2-}$. Dessa forma, verifica-se a complexidade dos parâmetros envolvidos no processo de atenuação dos contaminantes pelo solo, percolado com chorume. 


\section{Coluna 1}

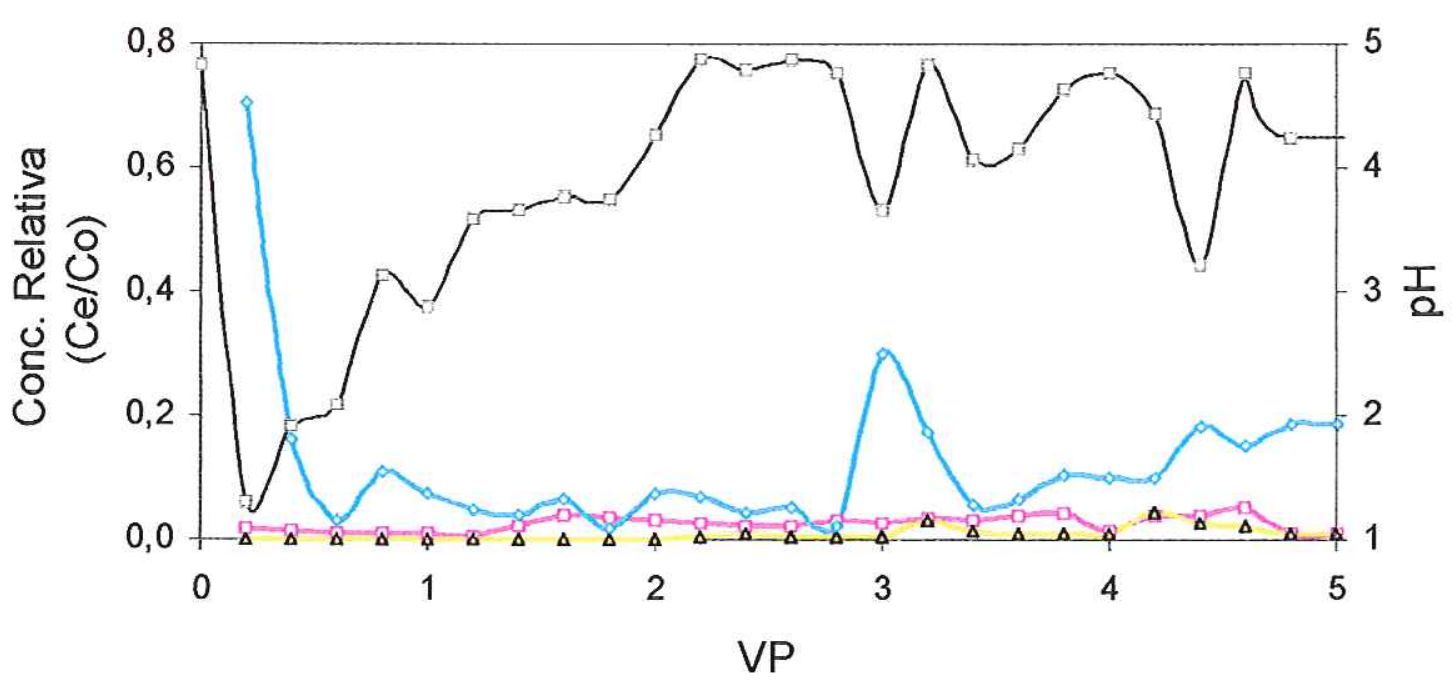

Coluna 2

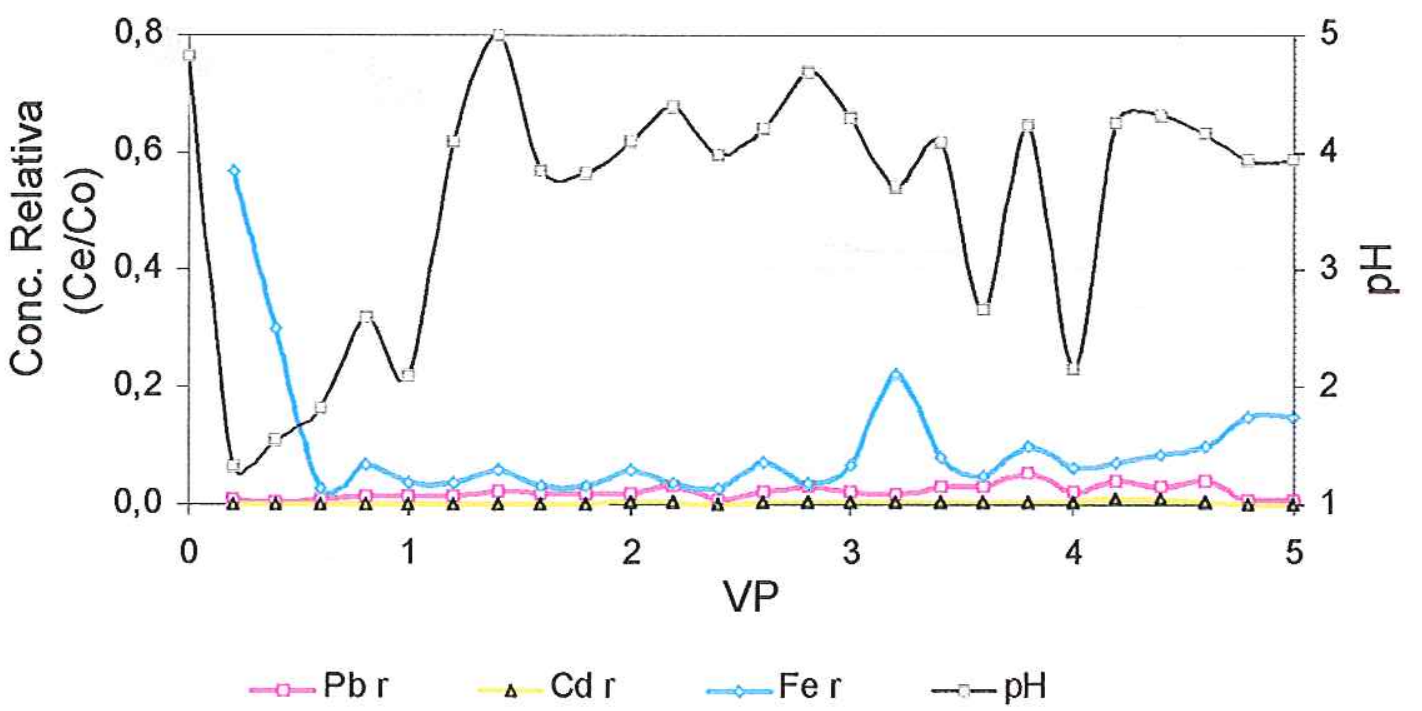

FIGURA 18 - Curvas de transporte para $\mathrm{Pb}, \mathrm{Cd}$ e Fe versus número de Vazios Percolados (VP) versus pH do chorume efluente nas Colunas 1 e 2

$\mathrm{Pb}$ r- Concentração relativa de Chumbo; $\mathrm{Cd}$ r- Concentração relativa de Cádmio e Fe r-Concentração relativa de Ferro

Por meio da curva característica de transporte para o Fe, verifica-se que esta tendeu à dessorção para ambas colunas analisadas, em pequenos trechos das curvas. Esse mecanismo coincidiu com a diminuição do valor de $\mathrm{pH}$ do chorume percolante, o que pode ter favorecido a liberação do elemento na solução. Foi observado com 
predominância de baixa mobilidade deste elemento no chorume percolante. De maneira geral, o Fe foi atenuado, visto que o chorume afluente nas colunas apresentava uma concentração de $85,6 \mathrm{mg} / \mathrm{L}$ e, ao longo dos 5,0 VP percolados, as concentrações apresentaram picos de $60,4 \mathrm{mg} / \mathrm{L}$ (que é uma concentração menor que a inicial) e valores baixos como $1,5 \mathrm{mg} / \mathrm{L}$.

A partir de 3,0 VP, observou-se pela FIGURA 15 a presença de um ambiente predominantemente redutor devido aos valores de Potencial Redox negativos, o que pode ter propiciado a presença da forma reduzida do $\mathrm{Fe}^{2+}$, que é solúvel e móvel. Esse ambiente redutor permite a movimentação de $\mathrm{Fe}^{2+}$ pelas colunas. $\mathrm{O}$ ambiente oxidativo favorece a formação de $\mathrm{Fe}^{3+}$, que é a forma precipitada e insolúvel e, pouco estaria se observando esse elemento nos efluentes coletados.

As curvas características de transporte para $\mathbf{P b}$ e $\mathbf{C d}$ apresentadas na FIGURA 18 mostram que estes elementos foram fortemente atenuados pelo solo presente nas colunas, ou seja, estes dois elementos, tanto para a coluna 1 e 2 , foram sorvidos durante os 5,0 VP percolados. Este fato pode ser comprovado pela comparação entre o chorume afluente e as amostras efluentes. O chorume que entrou nas colunas apresentava uma concentração de $5,34 \mathrm{mg} / \mathrm{L}$ de $\mathrm{Pb}$ e $5,30 \mathrm{mg} / \mathrm{L}$ de $\mathrm{Cd}$ As amostras efluentes coletadas a cada 0,2 VP apresentavam concentrações entre 0,030 e $0,290 \mathrm{mg} / \mathrm{L}$ de $\mathrm{Pb}$ e entre 0,006 e $0,220 \mathrm{mg} / \mathrm{L}$ de $\mathrm{Cd}$ para ambas colunas analisadas.

Essas concentrações efluentes refletem atenuação desses metais pelo solo, conforme item 4.4 onde foram apresentadas os perfis de metais retidos pelo solo. Observa-se que para ambos metais as concentrações afluentes são praticamente iguais, mas que nas amostras efluentes foi verificado uma maior concentração de $\mathrm{Cd}$ do que de $\mathrm{Pb}$. Isso se deve ao fator de seletividade de adsorção. Segundo YONG et al. (1992), para $\mathrm{pH}$ do solo $>3,0$ a ordem de seletividade é $\mathrm{Pb}>\mathrm{Cu}>\mathrm{Zn}>\mathrm{Cd}$ e, portanto, o $\mathrm{Pb}$ é preferencialmente adsorvido pelo material sólido do solo. Essa retenção também foi verificada por OLIVEIRA (2002), que em ensaios de percolação mostrou que o $\mathrm{Pb}$ estava presente em baixas concentrações nos efluentes coletados, o que realça a capacidade de retenção do metal pelo material sólido utilizado na pesquisa. 


\section{Coluna 1}

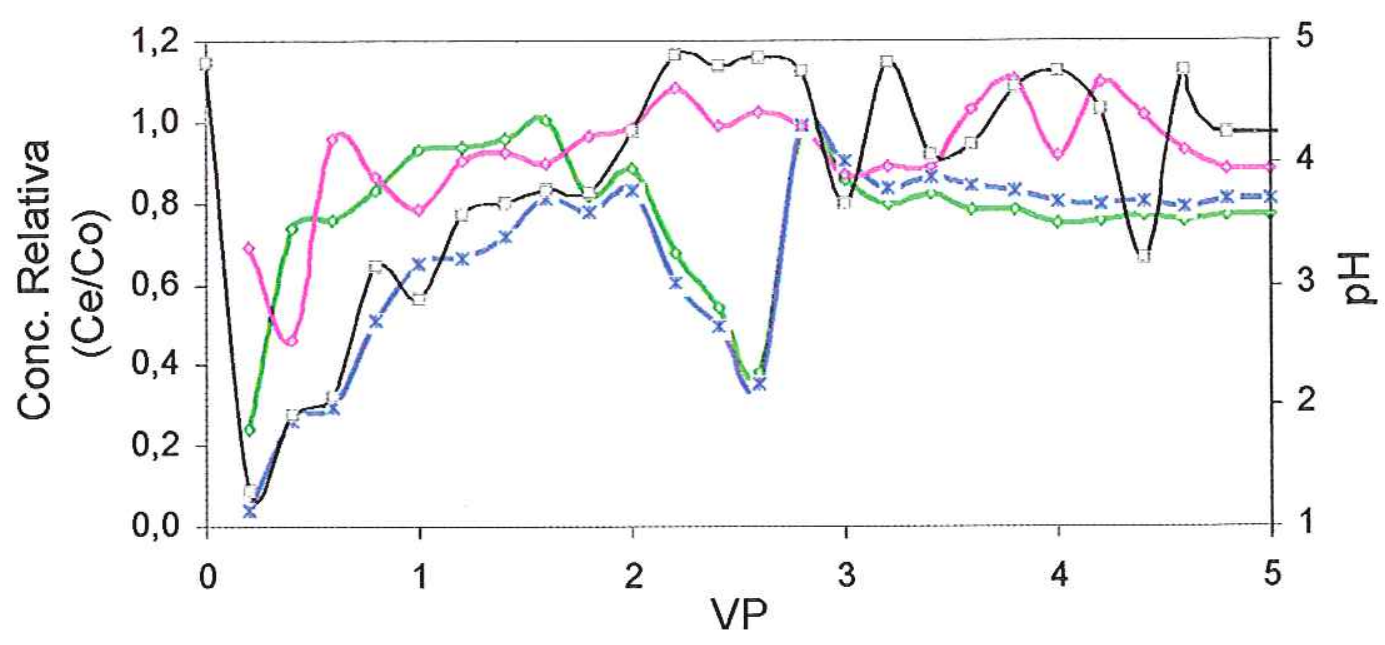

Coluna 2

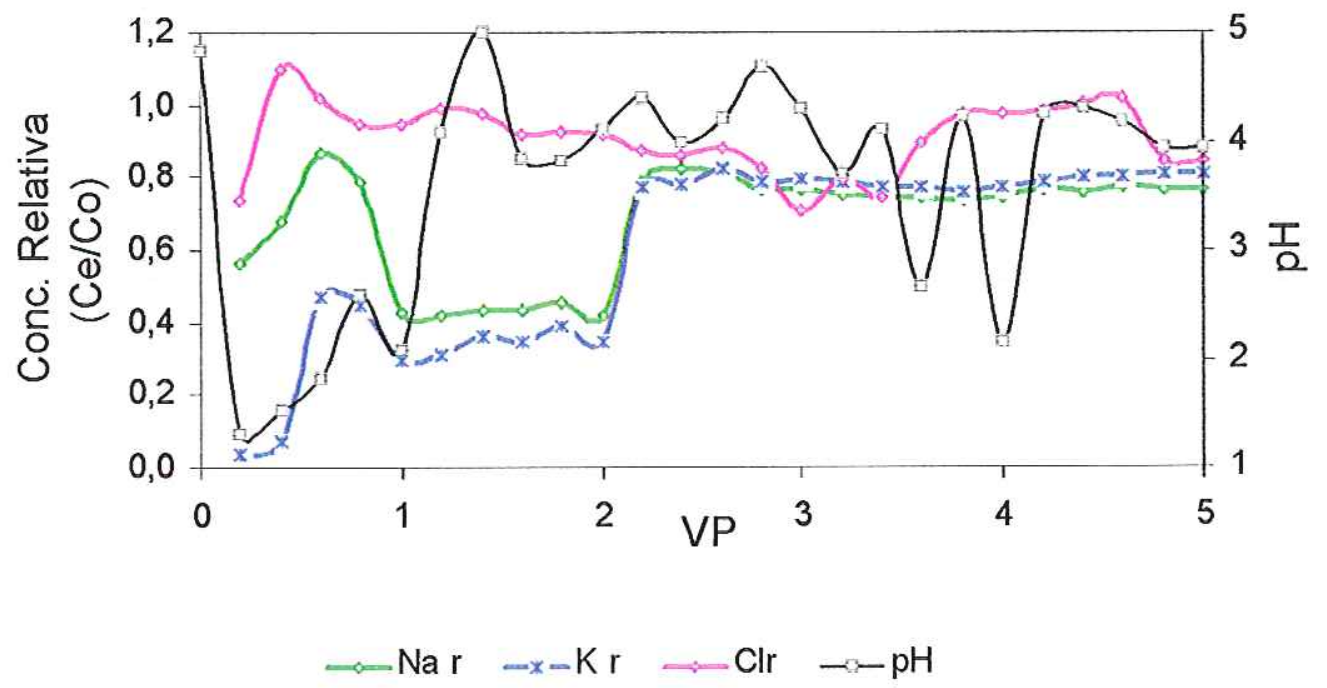

FIGURA 19 - Curvas de transporte para $\mathrm{Na} \mathrm{K}$ e $\mathrm{Cl}$ versus número de Vazios Percolados (VP) versus $\mathrm{pH}$ do chorume efluente nas Colunas 1 e 2

Na r- Concentração relativa de Sódio; K r- Concentração relativa de Potássio e $\mathrm{Cl}$ r- Concentração relativa de Cloro

Os elementos Na, $\mathbf{K}$ e $\mathbf{C l}$ apresentaram comportamentos parecidos e correlacionados, os quais podem ser verificados nas curvas características de transporte da FIGURA 19.

Os teores desses elementos $(\mathrm{Na}, \mathrm{K} \mathrm{e} \mathrm{Cl})$ nos efluentes coletados são elevados e constantes indicando a abundância destes íons no percolado, provavelmente devido à 
elevada solubilidade apresentada pela maioria dos sais que contém estes elementos em um ambiente de pH baixo, facilitando o processo de solubilização e/ou de lixiviação verificados nesse sistema (LEPROVOST ${ }^{6}, 1975$ apud OLIVEIRA et al., 2004).

Nestas curvas foi possível verificar que o K é mais atenuado que o $\mathrm{Na}$ e este mais que o $\mathrm{Cl}$. Este fato também foi verificado durante a percolação com chorume e em estudo realizado por CHRISTENSEN et al. (2001), o qual mostrou que o K tem alta afinidade por troca iônica e Na menos afinidade com este processo, o que faz com que o $\mathrm{K}$ fique preferencialmente mais retido do que o $\mathrm{Na}$ e este mais que o $\mathrm{Cl}$.

As curvas apresentadas na FIGURA 19 mostram um predomínio do mecanismo de dessorção, o que pode estar ocorrendo devido à substituição destes íons por outros de capacidade de troca superior, fato que não permite definir qual elemento estaria sendo preferencialmente trocado, devido à complexidade de composição do chorume percolante. Assim, esses elementos estão sendo pouco atenuados e as curvas aqui apresentadas condizem com o que realmente ocorre, segundo os autores já citados, tendo em vista a complexidade dos parâmetros envolvidos.

O Cl tem pouca afinidade com os minerais e muita afinidade com a água, o que o torna um indicador de contaminação (OLIVEIRA et al., 2002). Este elemento tem sido escolhido como tal, pois não é facilmente adsorvido pelo solo e é difícil de se decompor (CHEN \& WANG, 1996). Estes fatos explicam o comportamento do $\mathrm{Cl}$ durante os 5,0 VP percolados com chorume, ou seja, o elemento não sofreu reatividade com o solo presente nas colunas, podendo estar ligado à molécula da água presente no chorume percolante, onde a concentração afluente foi praticamente a mesma encontrada nas amostras efluentes durante toda a percolação.

${ }^{6}$ LEPROVOST, A. Química analítica dos minerais. Rio de Janeiro. Editora Livros Técnicos e Científicos. 393 p., 1975: 


\section{Coluna 1}

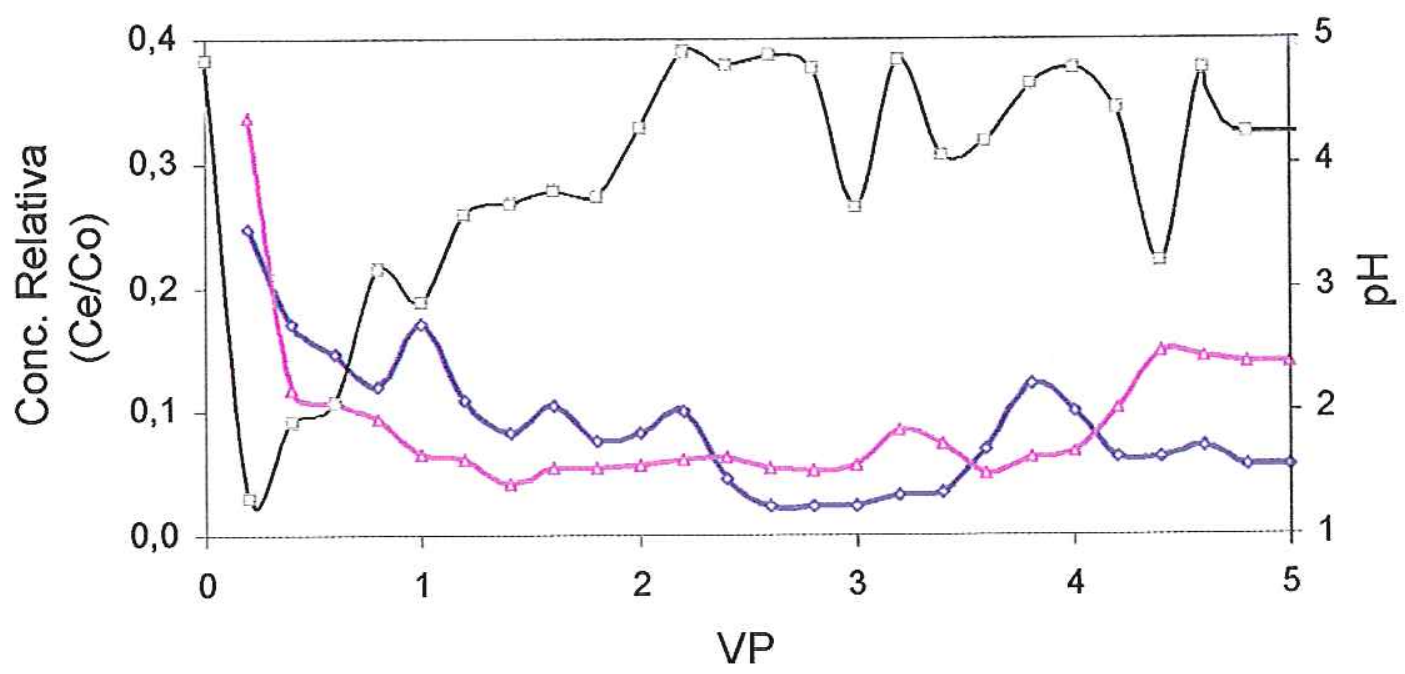

\section{Coluna 2}

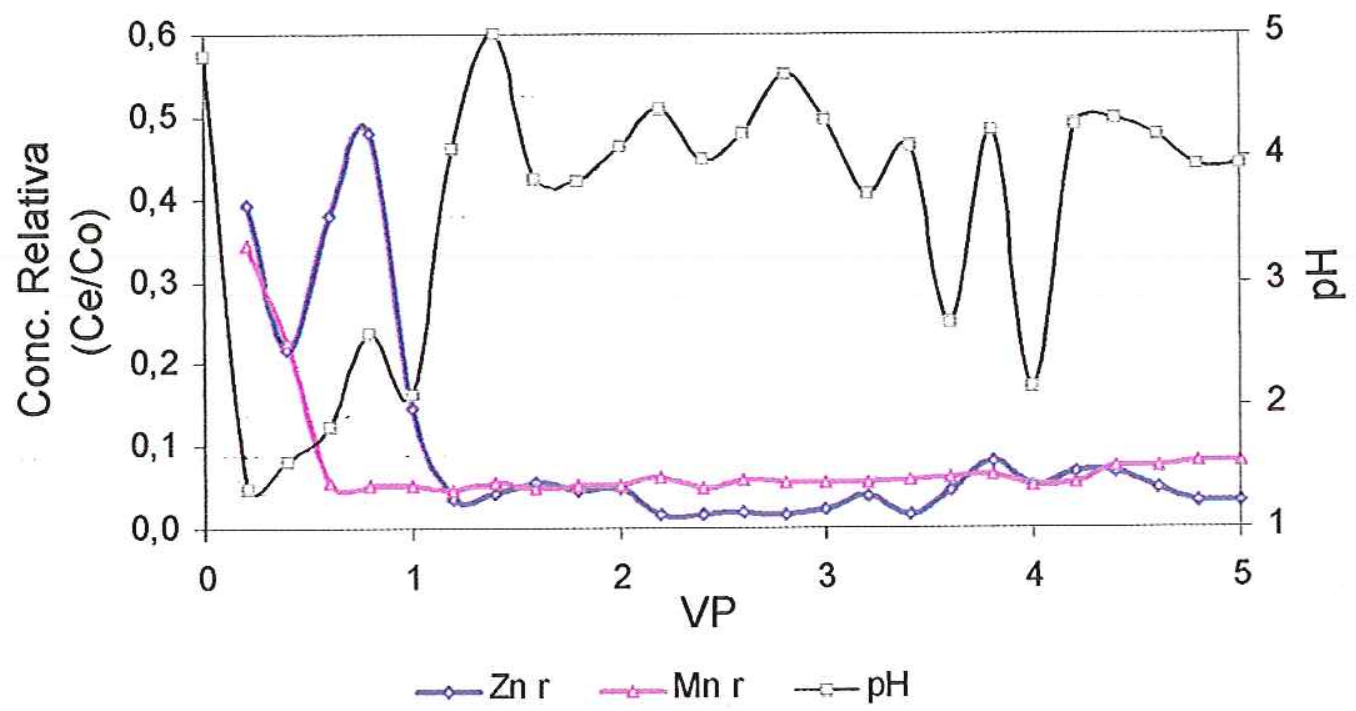

FIGURA 20 - Curvas de transporte para $\mathrm{Zn}$ e Mn versus número de Vazios Percolados (VP) versus $\mathrm{pH}$ do chorume efluente nas Colunas 1 e 2

Zn r- Concentração relativa de Zinco; Mn r- Concentração relativa de Manganês

As curvas de transporte para $\mathbf{Z n}$ e Mn observadas na FIGURA 20 são semelhantes e representam a atenuação destes elementos pelo solo. A atenuação é comprovada pela concentração dos elementos no chorume afluente versus os efluentes. O chorume que entrou nas colunas apresentava 3,67 mg/L de $\mathrm{Zn}$ e $19 \mathrm{mg} / \mathrm{L}$ de $\mathrm{Mn}$. Os efluentes coletados durante os 5,0 VP percolados apresentaram picos de 1,44 mg/L e 
quedas de $0,055 \mathrm{mg} / \mathrm{L}$ para $\mathrm{Zn}$ e picos de $6,41 \mathrm{mg} / \mathrm{L}$ e quedas de $0,79 \mathrm{mg} / \mathrm{L}$ para $\mathrm{Mn}$ em ambas colunas. Este fato realça a capacidade de retenção do metal pelo solo presente nas colunas, conforme apresentado no item 4.4. nos perfis de retenção de metais.

\section{Coluna 1}

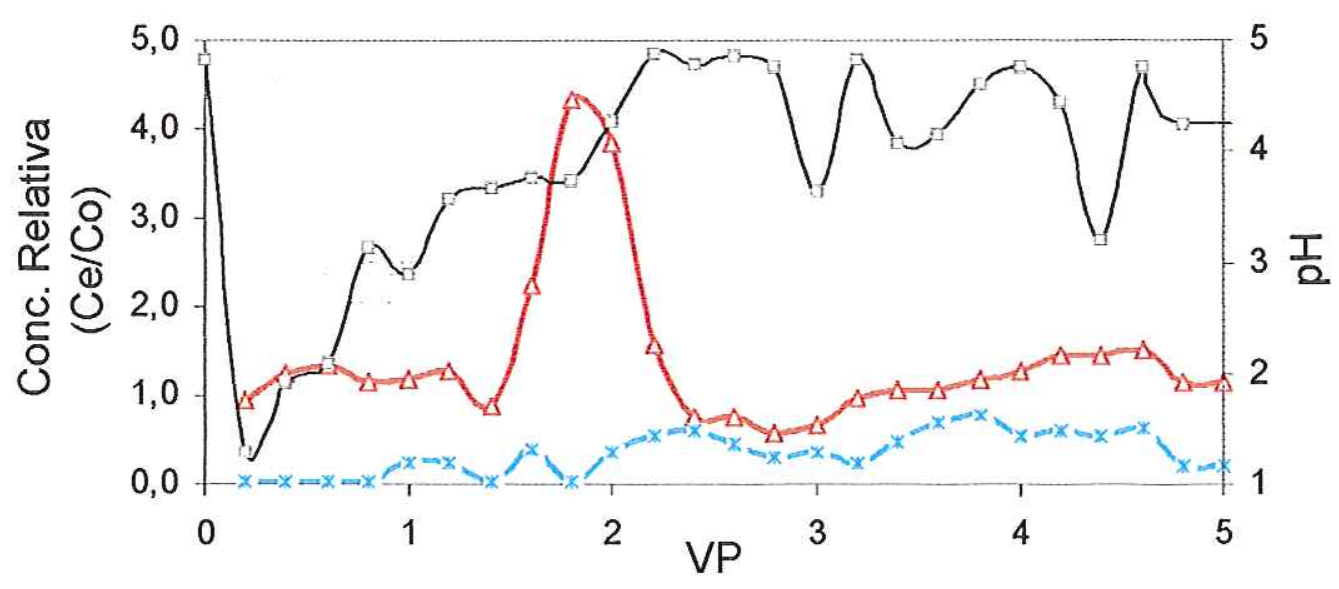

\section{Coluna 2}

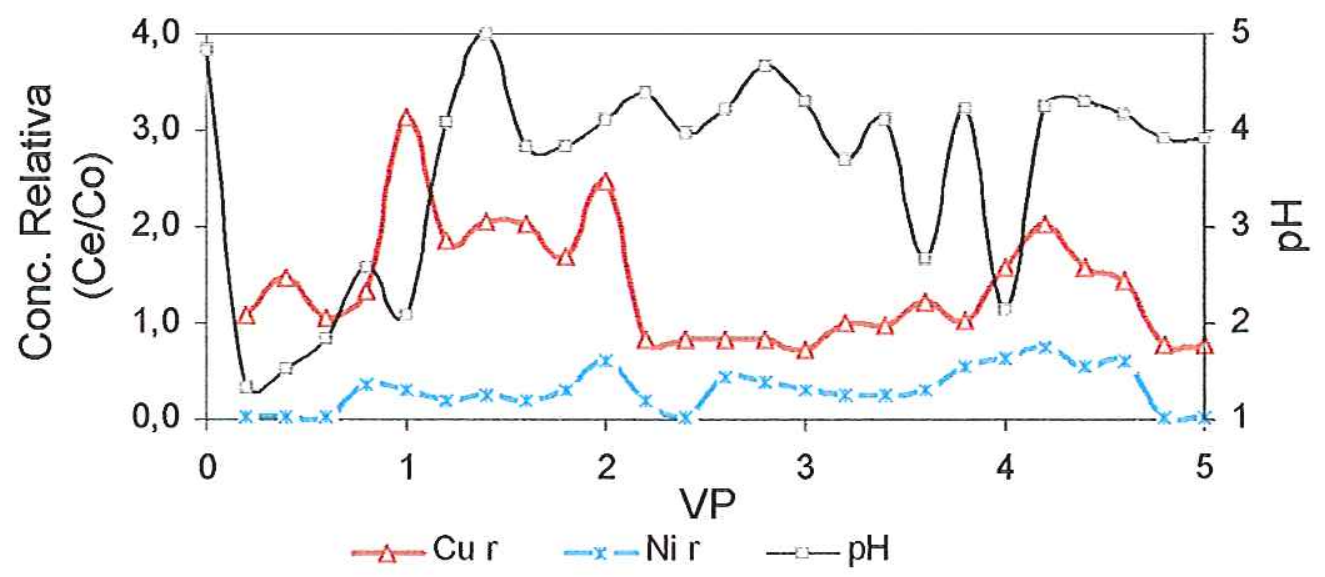

FIGURA 21 - Curvas de transporte para $\mathrm{Cu}$ e $\mathrm{Ni}$ versus número de Vazios Percolados (VP) versus $\mathrm{pH}$ do chorume efluente nas Colunas 1 e 2

$\mathrm{Cu}$ r-Concentração relativa de Cobre; Ni r- Concentração relativa de Níquel

O Cu teve comportamento peculiar nas curvas características de transporte durante os 5,0 VP percolados com chorume, mostrando típica dessorção deste elemento. ALKER et al. (1995) descrevem que os principais mecanismos de atenuação deste elemento em aterros sanitários são a absorção, troca iônica e precipitação. Para este ensaio pode-se dizer que o principal mecanismo foi a troca iônica, devido ao caráter ácido do meio em que ocorreu a percolação (tanto do solo quanto do chorume). 
Segundo YONG et al. (1992) sob pH baixo o mecanismo de troca de cátions (dessorção e dissolução) predomina e o metal pesado ganha mobilidade e, a adsorção nas partículas de solo pode diminuir devido à competição de sítios de troca pelo $\mathrm{H}^{+}$.

O Ni foi constantemente observado nas amostras efluentes. Ou seja, a concentração inicial deste elemento no chorume afluente era de $0,20 \mathrm{mg} / \mathrm{L}$ e, no decorrer da percolação e coleta das amostras efluentes este elemento apresentou concentrações variadas de $0,160 \mathrm{mg} / \mathrm{L}$ à $0,009 \mathrm{mg} / \mathrm{L}$, mostrando que também foi atenuado pelo solo presente nas colunas.

De maneira geral, as características de retenção diferem entre os metais e entre os tipos de solo, pois a preferência de adsorção entre as espécies metálicas não é igual para os diferentes tipos de solo. É necessário entender os mecanismos de adsorção envolvidos na retenção de metais pesados e o papel dos vários constituintes, tanto no solo quanto no chorume contaminante (YONG et al., 1992), o que se torna uma tarefa difícil, uma vez que o chorume tem composição muito complexa e variada.

\subsection{PERFIL DE RETENÇÃO DE CONTAMINANTES INORGÂNICOS PELAS COLUNAS DE SOLO}

Após a percolação de 5,0 volumes de poros com chorume nas colunas experimentais preenchidas com solo - lembrando que uma das colunas foi percolada com água isenta de contaminantes - estas foram desmontadas e amostras foram retiradas na forma de fatias, igualmente espaçadas ao longo das colunas.

Essas amostras foram analisadas quanto ao conteúdo de metais em aparelho de Espectrometria de Absorção Atômica após digestão ácida com $\mathrm{HCl}$ 0,1M (CETESB, 1994).

Os resultados dessas análises podem ser observados nas FIGURAS 22 a 24, por meio das quais são apresentadas os perfís de concentração dos metais investigados. 


\section{Perfil de Retenção-Coluna 1}

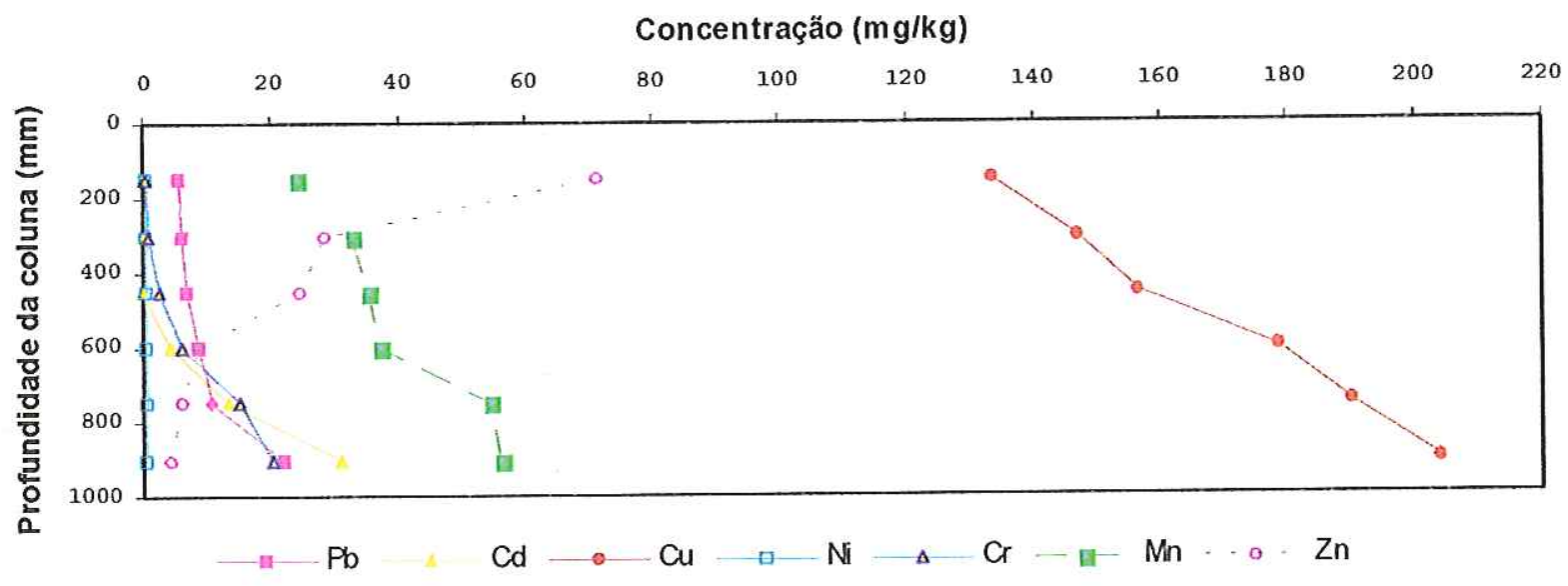

\section{Concentração $(\mathrm{mg} / \mathrm{kg})$}

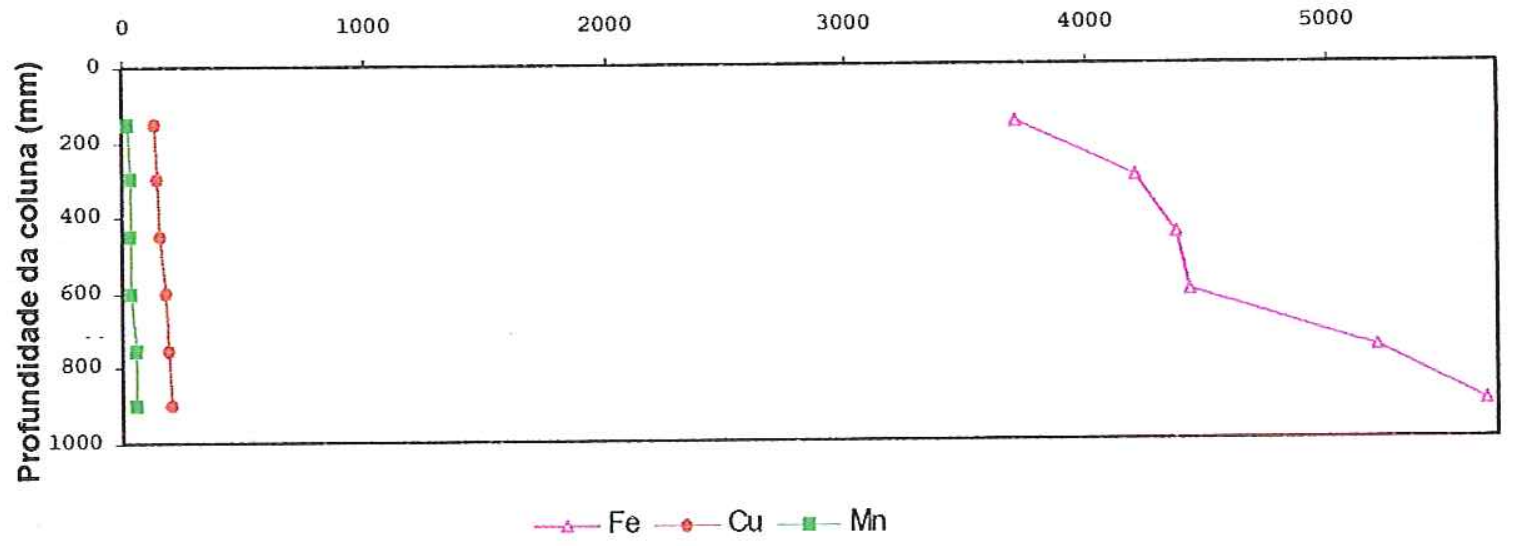

FIGURA 22 - Perfil de distribuição de metais após 5,0 Volumes de Poros percolados com chorume na Coluna 1 
Perfil de Retenção-Coluna 2
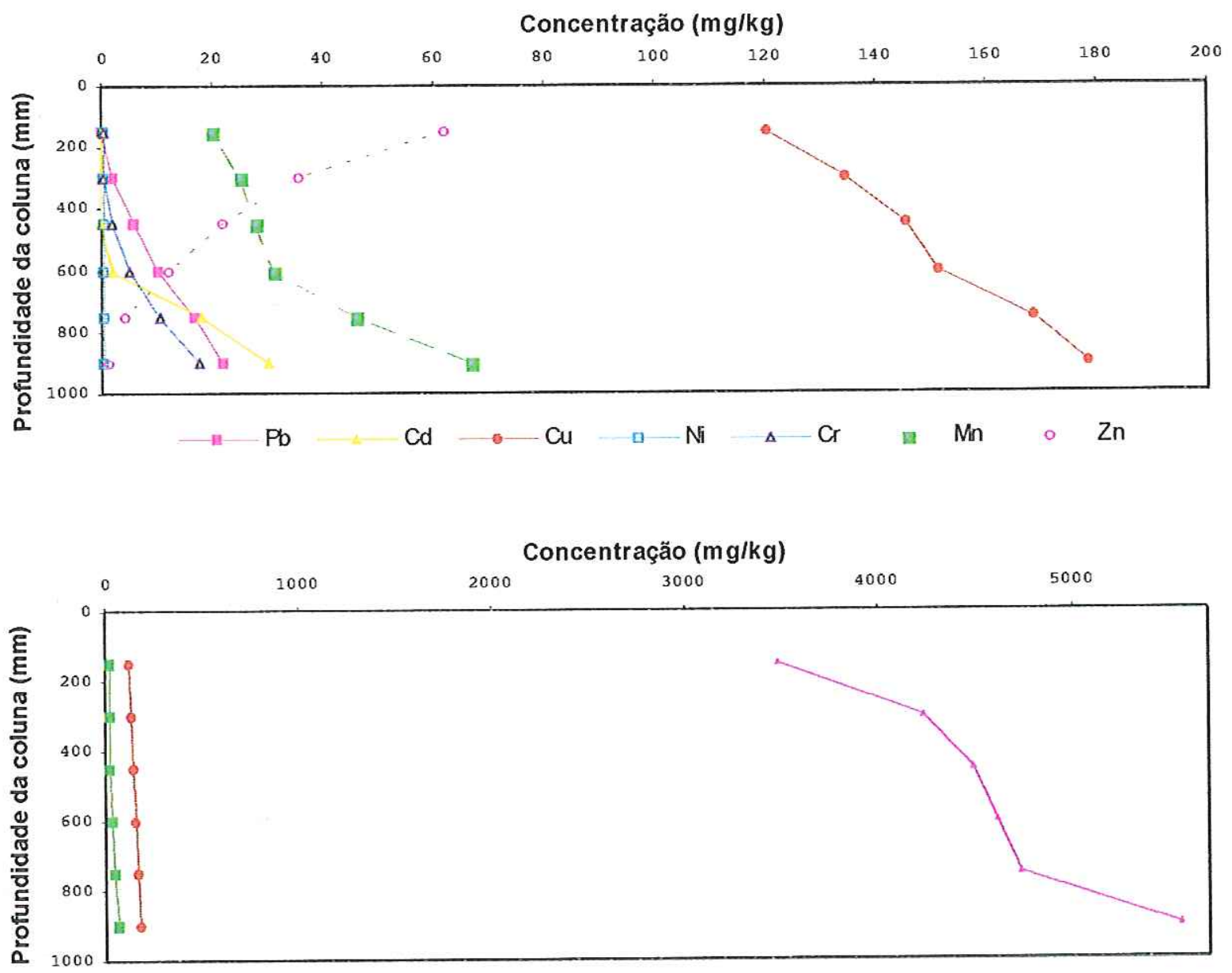

$$
\therefore \mathrm{Fe} \rightarrow \mathrm{Cu} \rightarrow \mathrm{Mn}
$$

FIGURA 23 - Perfil de distribuição de metais após 5,0 Volumes de Poros percolados com chorume na Coluna 2 


\section{Perfil de Retenção-Coluna 3}
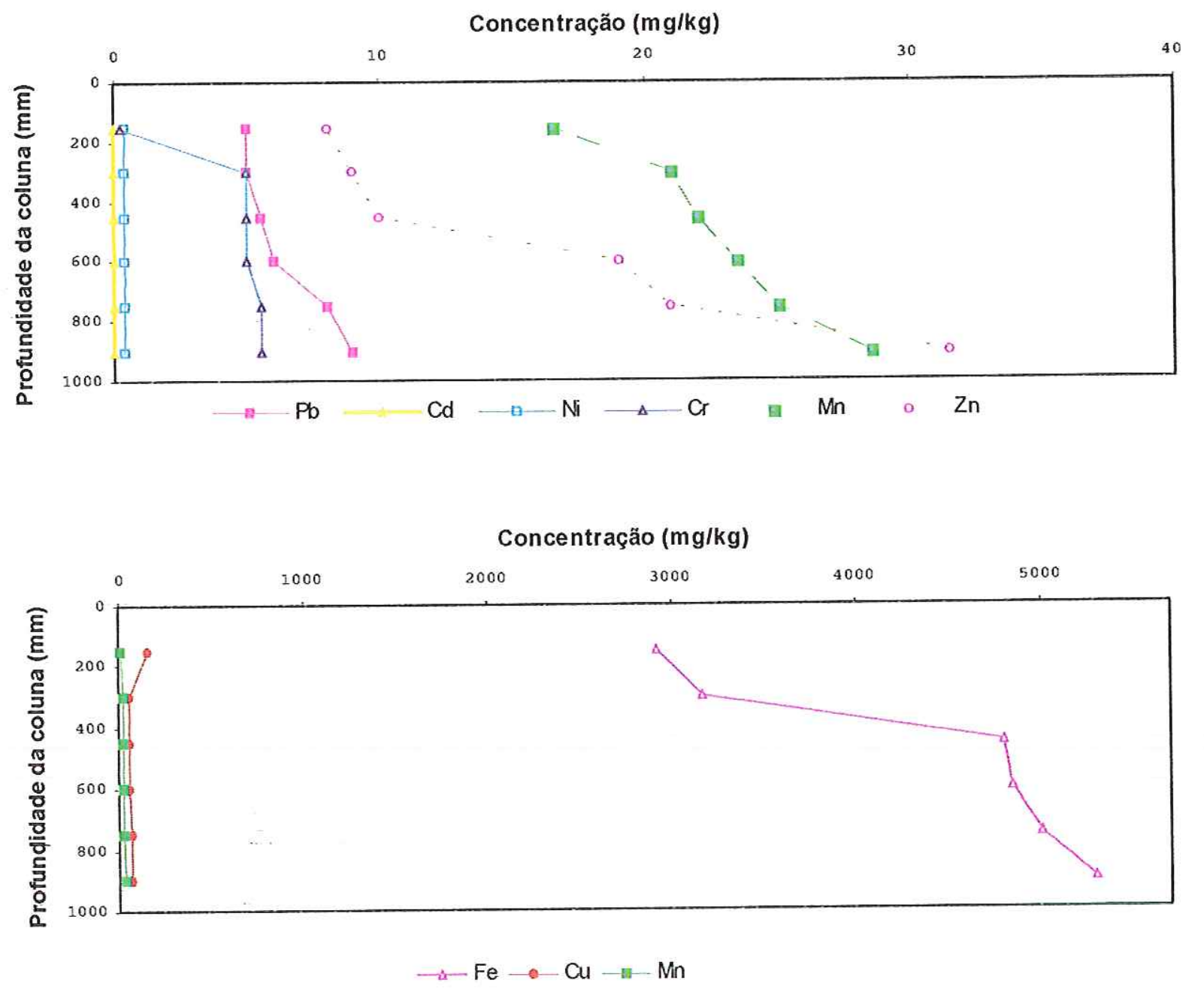

FIGURA 24 - Perfil de distribuição de metais após 5,0 Volumes de Poros percolados com água na Coluna 3

Os teores de metais trocáveis do solo coletado em campo para preenchimento das colunas foram analisados e as concentrações de $\mathrm{Pb}, \mathrm{Cd}, \mathrm{Ni}$ e $\mathrm{Cr}$ ficaram abaixo do limite de detecção do aparelho, sendo detectados apenas os teores de $\mathrm{Zn}(32 \mathrm{mg} / \mathrm{Kg}), \mathrm{Fe}$ (5500 mg/Kg), Mn (29 mg/Kg) e Cu (50 mg/Kg).

Comparando-se os resultados observados nas FIGURAS 22, 23 e 24, com os teores no solo antes de sua colocação nas colunas, nota-se que após a finalização do experimento, quando as colunas foram desmontadas e amostradas, as concentrações 
obtidas de $\mathrm{Pb}$ foram superiores em até 97 vezes, de $\mathrm{Cd}$ em até 226 vezes, de $\mathrm{Mn}$ em até 1,2 vezes, de $\mathrm{Cu}$ em até 3 vezes e $\mathrm{Cr}$ em até 25 vezes. Esses valores de metais retidos podem estar evidenciando a capacidade deste solo em reter contaminantes inorgânicos, apesar de suas características físico-químicas não serem favoráveis a tal processo. Assim, os metais preferencialmente retidos no solo das colunas foram $\mathrm{Cd}, \mathrm{Pb}, \mathrm{Cr}, \mathrm{Cu}$ e $\mathrm{Mn}$.

Continuando a estudar os perfis de retenção de metais pelo solo percolado com chorume nas FIGURAS 22 e 23 observa-se que os perfis apresentaram clara frente de contaminação em direção à parte superior da coluna, por onde as amostras efluentes foram coletadas. $\mathrm{O}$ formato das curvas de retenção obtidas para os elementos $(\mathrm{Pb}, \mathrm{Cd}$, $\mathrm{Cu}, \mathrm{Ni}, \mathrm{Cr}, \mathrm{Mn}, \mathrm{Zn}$ e $\mathrm{Fe}$ ) foi semelhante às formas apresentadas por OLIVEIRA et al., (2004) na investigação do acúmulo de metais em solo imediatamente abaixo de uma célula de aterro de resíduos sólidos e por CASSIANO (2004) ao verificar o perfil de retenção de metais por material sólido do Aqüífero Guarani percolado com chorume com característica alcalina.

A análise geral dos perfis de concentração dos metais pesados apresentados permite verificar uma ampla faixa de variação nas concentrações destes elementos, porém suas distribuições em função da profundidade são semelhantes nas colunas analisadas. $\mathrm{Ou}$ seja, o $\mathrm{Fe}, \mathrm{Cu}, \mathrm{Mn}, \mathrm{Cr}, \mathrm{Cd}$ e $\mathrm{Pb}$ foram retidos principalmente na parte basal das colunas, por onde foi feita alimentação com chorume

$\mathrm{O} \mathrm{Zn}$ apresentou comportamento oposto aos demais metais analisados, pois o enriquecimento em suas concentrações foi observado nas porções superiores das colunas e, o $\mathrm{Ni}$ não apresentou expressivo enriquecimento, mantendo-se em concentrações constantes por toda a coluna.

$\mathrm{O}$ comportamento dos perfis de retenção para $\mathrm{Ni}$ e, em menor proporção para $\mathrm{Cr}$, $\mathrm{Cd}$ e $\mathrm{Pb}$ indica que no início do teste de percolação pode ter ocorrido a mobilização destes metais, fazendo com que estes permanecessem em solução por mais tempo e se deslocassem para as porções superiores das colunas.

Já o $\mathrm{Zn}$ pode ter sofrido dissolução durante a percolação, fazendo com que este se concentrasse na parte superior da coluna. O Mn (assim como $\mathrm{Cu}, \mathrm{Pb}, \mathrm{Cr}, \mathrm{Cd}$ e $\mathrm{Fe}$ ) apresentou comportamento oposto ao $\mathrm{Zn}$, em que, provavelmente, após a imobilização inicial, este precipitou na forma de oxi-hidróxidos, ficando temporariamente imobilizados nesta forma. 
Assim, o comportamento destes metais indicam possibilidade de deslocamento na pluma de contaminação, visto que a disponibilidade dos metais pesados está diretamente associada aos diferentes valores de $\mathrm{pH}$ e Eh do solo. Ambientes ácidos (como o presente) favorecem a mobilidade destes metais, por apresentarem solubilidade mais elevada (SALA et al., 2000).

Esses resultados de distribuição nos teores de metais estão de acordo com os encontrados por CASSIANO (2004). No referido trabalho, o preenchimento das colunas foi feito com material sólido do Aqüífero Guarani. Essa semelhança pode ser explicada pelas semelhanças das características físicas e mineralógicas do material sólido de prenchimento das colunas em ambos experimentos.

O solo amostrado nas colunas após os 5,0 VP percolados com chorume, apresentou teores máximos de metais sorvidos: $\mathrm{Zn}=71 \mathrm{mg} / \mathrm{kg} ; \mathrm{Pb}=22 \mathrm{mg} / \mathrm{kg} ; \mathrm{Cd}=31$ $\mathrm{mg} / \mathrm{kg} ; \mathrm{Fe}=5750 \mathrm{mg} / \mathrm{kg} ; \mathrm{Mn}=66,5 \mathrm{mg} / \mathrm{kg} ; \mathrm{Cu}=204 \mathrm{mg} / \mathrm{kg} ; \mathrm{Ni}=0,4 \mathrm{mg} / \mathrm{kg}$ e $\mathrm{Cr}=$ $20,5 \mathrm{mg} / \mathrm{kg}$.

Por meio de análise conjunta das FIGURAS 18 a 24 foi verificado que, o Fe e o $\mathrm{Cu}$ foram os metais mais abundantes nos efluentes, bem como os mais abundantes no solo. Menores concentrações de Ni $(0,4 \mathrm{mg} / \mathrm{Kg}), \mathrm{Pb}(22 \mathrm{mg} / \mathrm{Kg})$ e $\mathrm{Cd}(31 \mathrm{mg} / \mathrm{Kg})$ retidos, que são valores baixos se comparados com os valores observados para Fe (5750 $\mathrm{mg} / \mathrm{Kg}$ ), refletem menores concentrações destes nos percolados efluentes. A partir dessa análise, torna-se evidente a relação entre a concentração do metal sorvido no solo e sua concentração no percolado (HAMADA et al. , 2004).

Esse comportamento pode ser explicado devido à relativa facilidade de troca que alguns cátions apresentam, sendo que estes estão sujeitos à troca de íons por adsorção aos minerais presentes no solo, em maior ou menor grau, em função da valência e dos raios iônicos dos elementos envolvidos (YONG et al.,1992). A preferência nos sítios de troca por um determinado metal em relação a outro é resultante da concentração relativa das soluções e também da carga líquida superfícial (BOFF, 1999). Portanto, a capacidade de atenuação é dependente da concentração, das espécies de solutos envolvidas e do comportamento eletroquímico do solo.

É importante salientar que durante o teste de percolação aqui desenvolvido o solo estava em suspensão, ou seja, a superfície exposta para a ocorrência das reações de sorção era a maior possível, sendo máximas as oportunidades de interação solocontaminante. Em uma amostra de solo natural (condições de campo), parte da 
superfície das partículas está em contato com partículas da solução contaminante, diminuindo a superfície disponível para a sorção (YONG et al., 1992).

Portanto, não foi possível distinguir e definir os mecanismos responsáveis pela retenção de metais, como adsorção, precipitação ou complexação. Foram analisadas as condições físico-químicas do ambiente de ocorrência das reações e, através das análises dos parâmetros físico-químicos, procurou-se verificar a tendência da ocorrência de determinados mecanismos de retenção dos metais.

Assim, o pH ácido do solo e do chorume que percolou nas colunas pode ter favorecido a ocorrência de reações de hidrólise, mantendo a maioria dos metais presentes na forma hidrolisada, propiciando uma adsorção estável entre os metais e a fase sólida do solo através da hidroxila, conforme GOMES et al. (1997).

ELLIOT $^{7}$ et al. (1986) e FAHHAR \& PICKERING (1977) apud OLIVEIRA et al., (2004) verificaram, utilizando teste de percolação em colunas, que o mecanismo de sorção preferencial dos metais pesados estava relacionado ao fenômeno de hidratação, o que geraria espécies mais facilmente sorvidas devido à afinidade com os grupamentos polares, presentes nas estruturas dos argilo minerais.

Isto é evidenciado pelo valor do $\mathrm{pH}$ do solo que apresentava-se numa faixa de 4,77, o que pode ter facilitado a hidratação dos metais e, conseqüentemente, maior acúmulo. Portanto o processo de retenção dos metais pelo solo em estudo pode estar relacionado com fenômenos de adsorção e de troca catiônica.

No entanto, considerando os valores médios da concentração de metais retidos no solo, através dos perfis de retenção gerados nas FIGURA 22 e 23, obtidos após 5,0 VP percolados com chorume, verificou-se retenção destes metais pelo solo, o que confirma os valores reduzidos nos efluentes coletados. Ou seja, o afluente apresentava uma certa concentração de metais, a cada 0,2 VP percolados as amostras efluentes coletadas apresentaram concentrações reduzidas, pois esse excedente não estava mais sendo observados nos efluentes, mas sim retidos no solo.

A FIGURA 24 mostra o perfil de distribuição dos metais na coluna preenchida com solo, mas percolada com água isenta de contaminantes, diferente das FIGURAS 22 e 23, que foram percoladas com chorume. A comparação da distribuição dos teores de metais nesta coluna 3 versus a concentração destes na amostra de solo coletada em

${ }^{7}$ ELLIOT, H.A.; LIBERATI, M.R.; HUANG, C.P. Competitive adsorption of heavy metals by soil. Journal Environmental Quality. V. 15, n.3, p. $214-219.1986$.

FAHHAR, H.; PICKERING, W.F. Influence of clay solute interactions on aqueous heavy metal ion levels. Water air and soil pollution. v.8, p. $189-197,1997$. 
campo, permitiu verificar que há mais $\mathrm{Pb}, \mathrm{Cu}$ e $\mathrm{Cr}$ no solo da coluna do que o amostrado em campo, mas que no geral, para os demais metais, a concentração destes coincide em ambos. Esse aumento da concentração para esses metais pode ser devido às reações de hidrólise da água percolante com esses elementos adsorvidos às superfícies dos minerais e, também, ao $\mathrm{pH}$ ácido do solo, que possivelmente reagiu com o $\mathrm{pH}$ neutro $(7,7)$ da água percolante. Ao entrar na coluna, essa pode ter sofrido reações de neutralização, promovendo possíveis precipitações desses elementos.

No presente estudo foi observado que a capacidade de retenção de metais pelo solo é evidente, porém faz-se necessário um estudo com percolação por períodos mais longos, pois os resultados experimentais, mesmo mostrando tendência na retenção de elementos e substâncias potencialmente poluentes presentes nos líquidos percolados de aterros sanitários, não são totalmente conclusivos, reforçando a necessidade de incrementar estudos dessa natureza no desenvolvimento de projetos para o monitoramento de aterros de disposição final de resíduos sólidos urbanos. 


\section{CONSIDERAÇÕES FINAIS}

- O solo do aterro sanitário do município de São Carlos no teste de coluna em laboratório funcionou como um filtro, tendo a capacidade de depuração e imobilizando impurezas nele depositadas, apresentando potencial para retenção dos contaminantes presentes no chorume, apesar de ser classificado como arenoso e de suas características químicas não se enquadrarem nos parâmetros adequados para sua utilização em áreas de disposição de resíduos sólidos urbanos. Essas características podem ser melhoradas através de sua mistura com geossintéticos, o que acarreta certa economia na construção de camadas impermeabilizantes, dispensando o uso de argilas e evitando o transporte de locais distantes do aterro;

- A capacidade atenuadora do solo é limitada, podendo ocorrer alteração de sua qualidade, devido ao efeito acumulativo da deposição dos poluentes ocorrida ao longo da percolação com o chorume;

- O percolado do aterro sanitário de São Carlos apresentou elevados teores de DQO, Condutividade Elétrica, Turbidez, Eh e baixos valores de $\mathrm{pH}$, o que o enquadra na fase ácida de estabilização da matéria orgânica, tornando-o um potencial poluente para o solo e recursos hídricos da região.

- Os macrocomponentes $\mathrm{Na}, \mathrm{K}$ e $\mathrm{Cl}$ apresentaram-se pouco reativos e alta mobilidade, pois foram os preferencialmente lixiviados com o chorume percolante, observados nas curvas características de transporte de contaminantes;

- Os valores de metais retidos no solo das colunas $(\mathrm{Pb}, \mathrm{Cd}, \mathrm{Mn}, \mathrm{Cu}$ e $\mathrm{Cr})$ podem estar evidenciando a capacidade deste solo em reter contaminantes inorgânicos; 
- $\mathrm{O} \mathrm{Cd}, \mathrm{Pb}, \mathrm{Cr}, \mathrm{Cu}$ e $\mathrm{Mn}$ foram preferencialmente sorvidos pelo solo em relação ao $\mathrm{Fe}$, $\mathrm{Zn}$ e Ni;

- Há uma relação entre a concentração do metal sorvido no solo e sua concentração no percolado, onde espécies mais concentradas no percolado apresentaram alta concentração no solo. Em termos quantitativos, o $\mathrm{Fe}$ e o $\mathrm{Cu}$ são os metais mais abundantes nos percolados efluentes e também os mais abundantes no solo. Menores concentrações de $\mathrm{Cd}, \mathrm{Pb}, \mathrm{Cr}$ e $\mathrm{Ni}$ no percolado efluente refletem em baixa concentração destes no solo;

- Não foi possível distinguir e definir com precisão os mecanismos responsáveis pela retenção de metais devido à complexidade dos parâmetros envolvidos no desenvolvimento do teste de percolação em colunas e, também, devido à composição muito variada do chorume percolante, o que torna difícil o controle de todos os parâmetros envolvidos;

- As informações disponíveis dos processos de atenuação pelo solo têm sido incrementadas nos últimos anos, mas o número de atenuações documentadas por material de característica arenosa é baixa e a diversidade dos processos de atenuação ainda não é bem entendida. Portanto, há necessidade de se incrementar esses dados, pois aparentemente os processos de atenuação de plumas de contaminantes de chorume pode, para muitos contaminantes, significar natural remediação, limitando os efeitos prejudiciais da presença de chorume em águas subterrâneas. 


\section{SUGESTÕES PARA TRABALHOS FUTUROS}

- Em decorrência do aprendizado obtido com os ensaios efetuados, stugère-se a continuidade dos estudos de contaminação nos solos de aterros sanitários, abrangendo os seguintes aspectos: uso de artifícios matemáticos para obtenção de balanço de massa dos metais retidos no solo, realização de estudos de contaminação em baixas taxas de fluxo e aprofundamento na investigação de possíveis reações de sorção quando da contaminação dos solos pelos percolados de aterro;

- A análise mineralógica qualitativa dos solos revela a importância dos óxidos e hidróxidos de $\mathrm{Fe}$ e $\mathrm{Al}$ na capacidade sorciva dos solos. Por isso, sugere-se análises mineralógicas quantitativas destes componentes;

- Há uma certa limitação para o emprego dos resultados obtidos que, embora relevantes, devem ser avaliados com cautela quando se vislumbra o emprego deste tipo de solo sob condições de campo. O estudo foi realizado em condições de laboratório e a alimentação de água e chorume nas colunas foi controlada de maneira uniforme, situação difícil de ocorrer em campo. Portanto, os resultados merecem estudos complementares, inclusive sob condições de campo;

- Para avaliar o transporte de contaminantes, além dos parâmetros determinados em laboratório, faz-se necessário um estudo em escala de campo para conhecer o comportamento destes contaminantes in situ. 


\section{REFERÊNCIAS BIBLIOGRÁFICAS}

AGNELLI, N. (1997). Comportamento de um solo colapsível inundado com líquidos percolados de diferentes composições químicas. Tese (Doutorado). Escola de Engenharia de São Carlos, Universidade de São Paulo. São Carlos, 1997.

ALKER, S.C.; SARSBY, R.W.; HOWELL,R. (1995). The composition of leachate from waste disposal sites. In: GREEN 93, Balkema, Roterdam. 1995. Anais. Rotterdam, ISBN. P.215-223.

ASSOCIAÇÃO BRASILEIRA DE NORMAS TÉCNICAS. (1984a). NBR 7181 - Solo: análise granulométrica. Associação Brasileira de Normas Técnicas. Rio de Janeiro.

$\overline{\text { Janeiro. }}$

(1984b). NBR 6508 - Solos: determinação de massa específica. Rio de ,

. (1985). NBR 8849 - Apresentação de projetos de aterros controlados de resíduos sólidos. Rio de Janeiro.

. (1986a). NBR 6457 - Solos: preparação para ensaios de compactação e caracterização. Rio de Janeiro.

(1986b). NBR 7182 - Solos: ensaios de compactação. Rio de Janeiro.

de Janeiro.

(1989). NBR 5734 - Peneiras para ensaio com telas de tecido metálico. Rio . (1992). NBR 8419 - Apresentação de projetos de aterros sanitários de resíduos sólidos urbanos: procedimento. Rio de Janeiro.

. (2004). NBR 10004 - Resíduos sólidos - classifícaçạao. Rio de Janeiro.

. (2004). NBR 10005 - Procedimento para obtenção de extrato lixiviado de resíduos sólidos. Rio de Janeiro. 
. (2004). NBR 10006 - Procedimento para obtenção de extrato solubilizado de resíduos sólidos. Rio de Janeiro.

___. (2004). NBR 1007 - Amostragem de resíduos sólidos. Rio de Janeiro.

, ALLOWAY, B.J. (Ed.). (1995). Heavy metals in soils. $2^{\text {nd }}$ ed. London: Blackie Academic \& Professional.

AMERICAN SOCIETY FOR TESTING AND MATERIALS - ASTM D 4874 - 95. (1995) Standard Test Method for leaching Solid Material in a Column Apparatus. 7p.

AMERICAN PUBLIC HEALTH ASSOCIATION; AMERICAN WATER WORKS ASSOCIATION; WATER ENVIRONMENTAL FEDERATION (1998). Standard methods for the examination of water and wasterwater. $20^{\text {th }} \mathrm{ed}$. Washington: APHA.

' ANTONIAlLI, A. (2002). Recuperação do lixão do Pau Queimado do Município de Piracicaba-SP transformando em aterro controlado. 108p. Dissertação (Mestrado) Centro de Estudo Ambientais, Universidade Estadual Paulista, Rio Claro. 2002.

, BEAR, J. (1972). Dynamics of fluids in porous media. New York: American Elsevier.

BIDONE, F.R.A.; POVINELLI, J. (1999). Conceitos básicos de residuos sólidos. São Carlos: EESC/USP.

BOFF, F.E. (1999). Avaliação do comportamento de uma mistura compactada de solos lateríticos frente a soluções de $\mathrm{Cu}^{++}, \mathrm{K}^{+}$e Cl em colunas de percolação. 190p. Dissertação (Mestrado) - Escola de Engenharia de São Carlos, Universidade de São Paulo, São Carlos. 1999.

/ BOURG, A.C.M.; LOCH, J.P.G. (1995). Mobilization of heavy metals as affected by $\mathrm{pH}$ an Redox Conditions. In: Biogeodynamics of pollutants in Soil and Sediments. Spronger-Verlag Berlim Heidelberg, p.87-101.

BRANCO, S. M. (1991). A água e o homem. In: PORTO, R. L. L. (org). Hidrologia Ambiental. São Paulo. EDUSP. Cap. 1, p. 3-25.

- BRANDL, H. (1992). Minerals liners for hazardous waste containment. Geotechnique. v.4, n.1, p.57-65.

CAMARGQ, O.A.et al. (1996). Métodos de análises químicas, mineralógicas e físicas das solos, Campinas: IAC. (Boletim Técnico, n.106). 
CASANOVA, F. J. O. C. (1989). Eletroquímica e Propriedades Mecânicas dos Solos. In: Colóquio de Solos Tropicais e Subtropicais e suas aplicações em Engenharia Civil, 2. Porto Alegre, 1989. Anais. Porto Alegre, CPGEC. P.43-59.

CASSIANO, A. M. (2004). Implicações Ambientais dos processos de atenuação de chorume em Aquífero. Relatório Científico apresentado a FAPESP. 10 p.

CARVALHO, J. B. Q. (1997). Fundamentos de Mecânica dos solos.

¿CHEREMISINOFF, P. N.(1995). Handbook of Water and Wastewater Treatment Technology. New York: Marcel Dekker, Inc. 833p.

CHEN, P.H.; WANG,C.Y.; Investigation into municipal waste leachate in the unsaturated zone of red soil. Environmental International, v.23,n.2, p. 237-245. 1997.

COMPANHIA DE TECNOLOGIA DE SANEMANETO AMBIENTAL (1994). Sólidos- Determinação de Metais por Espectofotometria de Absorção Atômica. Método de Extração Ácida. Norma L 5601. 1978. São Paulo.

(1997). Uso das águas subterrâneas para abastecimento público no Estado de São Paulo: 1997. São Paulo.

(2001a). Relatório de estabelecimento de valores orientadores para solos $e$ águas subterrâneas no Estado de São Paulo. São Paulo. (Série Relatórios).

(2001). Relatório de qualidade das águas subterrâneas nos Estado de São Paulo 1998 - 2000. São Paulo. (Série Relatórios).

(2003a). Glossário ecológico ambiental. Disponível $\overline{\mathrm{em}:<\mathrm{htt}}$ ://www.cetesb.sp.gov.br/Ambiente/glossario/glossario_a.asp>. Acesso em: 7 set. 2004.

(2004). Padrões de qualidade para os parâmetros monitorados na rede de monitoramento, segundo a resolução CONAMA 20/86. Disponível em: $<$ http://www.cetesb.sp.gov.br/agua/rios/padroes.htm>. Acesso em: 19 fev. 2004.

CHRISTENSEN, T.H. (1992a). Attenuation of leachate pollutants in groundwater. In: CHRISTENSEN, T.H.; COSSU, R.; STEGMANN, R. (Ed.). Landfilling of waste: leachate. London: Elsevier Applied Science. p.441-484.

CHRISTENSEN, T.H.; BJERG, P.L.; KJELDSEN, P. (2000). Natural attenuation: a feasible approach to remediation of groundwater pollution at landfills?. Ground Water Monitoring and Remediation, Dublin, v.20, n.1, p.69-77. 
CHRISTENSEN, T.H.; KJELDSEN, P. (1989). Basic biochemical processes in landfills. In: CHRISTENSEN, T.H.; COSSU, R.; STEGMANN, R. (Ed.). Sanitary landfilling: process, technology and environmental impact. London: Academic Press. p.

CHRISTENSEN, T.H.; KJELDSEN, P.; LARSEN,T. (1992). Sorption of hydrophobic hydrocarbons on three aquifer materials in a flow through system. Chemosphere, Oxford, v.24, n.4, p.439-451. Feb.

CHRISTENSEN, T.H. et al. (2001). Biogeochemistry of landfill leachate plumes. Applied Geochemistry, Oxford, v.16, n.7/8, p.659-718, June.

, CLARETO, C.R. (1997). Tratamento dos líquidos percolados gerados em aterros sanitários utilizando reator anaeróbio compartimentado. 119p. Dissertação (Mestrado) - Escola de Engenharia de São Carlos, Universidade de São Paulo, São Carlos. 1997.

DAMASCENO, S. (1996) Remoção de metais pesados em sistemas de tratamento de esgoto sanitário por processo de lodo ativado e por reator compartimentado anaeróbio. 141p. Dissertação (Mestrado em Hidráulica e Saneamento). Escola de Engenharia de São Carlos, Universidade de São Paulo, São Carlos, 1996.

/DEMATTÊ, J. O. I. (1989). Crso de Gênese e Classificação de solos. Centro Acadêmico Luiz de Queiroz (ESALQ). Piracicaba.

ELLIOT, H. A; LIBERATI, M.B.l; HUANG, C.P. (1986). Competitive adsorption of heavy metals by soil. Journal of Environmental Quality. v.15, n.3, p. 214 - 219.

ESTEVES, F.A. (1988). Fundamentos de Liminologia. Ed. Interciência/FINEP. 1 ed.

FORTES, R. M. (2004). Instrumentos de Gestão Ambiental aplicados aos empreendimentos rodoviários. $35^{\circ}$ Reunião Anual de Pavimentação. ABR - Associação Brasileira de Pavimentação, Rio de Janeiro - RJ, Brasil, 19 a 21 Outubro de 2004.

, FREEZE, R.A.; CHERRY, J.A. (1979). Groundwater. Englewood Cliffs: Prentice Hall.

-FREITAS, A.L.S. (1996). Caracterização do Aqüífero Botucatu na região do lixão de São Carlos. 113p. Dissertação (Mestrado) - Escola de Engenharia de São Carlos, Universidade de São Paulo, São Carlos. 1996.

GADOTTI, R.F. (1997). Avaliação da contaminação das águas superficiais e subterrrâneas adjacentes ao 'lixão'da cidade de São Carlos, SP. 143p. Dissertação (Mestrado) - Escola de Engenharia de São Carlos, Universidade de São Paulo, São Carlos. 1997. 
GOMES, P. C.; FONTES, M. P. F.; Da COSTA, L. M.; MENDONÇA, E. S. (1997). Extração fracionada de metais pesados em latossolo vermelho amarelo. Revista Brasileira de Ciência do Solo. Vol 21. p. 543 - 551.

, GUERRA, A.J.T.; CUNHA, S.B. (2003). Geomorfologia e meio ambiente. 4.ed. Rio de Janeiro: Bertrand Brasil.

, GUIMARÃES, L. T. (2000). Disponível em $\quad$ em

, GUSMÃO FILHO, J.A. (2002). Solos da formação geológica ao uso na engenharia. Recife: Ed.Universitária da UFPE.

HAMADA, J.; CALÇAS, D. A. N. Q. P.; GIACHETI, H. L. (2004). Influência da compactação de um solo arenoso na infiltração e retenção de carga orgânica de chorume. Revista Engenharia Sanitária Ambiental. vol.9, n. 3, p. 180-186.

- HEITZMANN JR., J.F. (1999). Alterações na composição do solo nas proximidades de depósitos de resíduos domésticos na Bacia do Rio Piracicaba, São Paulo, Brasil. São Paulo: Associação Brasileira de Geologia e de Engenharia. (Série Síntese de Tese, 9).

INSTITUTO BRASILEIRO DE GEOGRAFIA E ESTATÍSTICA (2002). Pesquisa nacional de saneamento básico 2000. Brasília: Ministério do Planejamento, Orçamento e Gestão. Disponível em: $<$ http://www.ibge.gov.br/home/presidencia/noticias/27032002pnsb.shtm>. Acesso em: 2 ago.2004.

' INSTITUTO DE PESQUISA TECNOLÓGICA DO ESTADO DE SÃO PAULO (1995). Lixo municipal: manual de gerenciamento integrado. São Paulo: IPT/CEMPRE. (Publicação IPT, 2163).

JENSEN, D.L.; CHRISTENSEN, T.H. (1999). Colloidal and dissolved metals in leachates from four Danish ladfills. Water Resources Research, New York, v.33, n.9, p.2139-2147, June.

KJELDSEN, P.; CHRISTENSEN, T.H. (1984). Soil attenuation of acid phase landfill leachate. Waste Manage Res., n. 2, p. $247-253$.

KNOX, C. R.; SABATINI, D.A.; CARTER, L.W. (1993). Subsurface Transport and Fate Process. Boca Raton, Florida: Lewis publishers.

LAFULENTE, J. G. C. (1969). Química del Agua. Madrid: Editoral Blume.355p.

LANGE, L.C. et al. (2001). Estudo do transporte de contaminantes em meios porosos aplicado a aterros de disposição de resíduos sólidos urbanos. In: ALTERNATIVAS de 
disposição de resíduos sólidos urbanos para pequenas comunidades: coletânea de trabalhos técnicos. São Carlos: Suprema. p.85-92.

, LARINI, L. (1993) Toxicologia. 2ed. Manole, São Paulo.

, LEITE, A.L. (1997). A difusão molecular do $\mathrm{K}^{+} \boldsymbol{e} \mathrm{Cl}$ em solos naturais compactados: uma perspectiva para uso em liners. 144p. Dissertação (Mestrado) - Escola de Engenharia de São Carlos, Universidade de São Paulo, São Carlos. 1997

LOPES, A.A. (2004). Estudo da gestão e do gerenciamento integrado dos resíduos sólidos urbanos na Bacia Tietê - Jacaré (UGRHI - 13). Exame de qualificação apresentado à Escola de Engenharia de São Carlos da Universidade de São Paulo, como parte dos requisitos para obtenção do título de Doutor em Ciências da Engenharia Ambiental. São Carlos, 2004.

, MALAVOLTA, E. (1994). Micronutriente e metais pesados: mitos, mistificação e fatos. São Paulo: Produquímica.

MATOS, A.T. (1995). Fatores de retardamento e coeficientes de dispersão-difusão dos metais zinco, cádmio, cobre e chumbo em solos do município de Viçosa-MG. 110p. Tese (Doutorado) - Universidade Federal de Viçosa, Viçosa. 1995.

, MATTIAZZO, M.E.; ANDRADE, C.A. (2000). Aplicabilidade do biossólido em plantações florestais: lixiviação de $\mathrm{N}$ orgânico e toxicidade de metais pesados. In: EMBRAPA MEIO AMBIENTE. Impacto ambiental do uso agrícola do lodo de esgoto. Jaguariúna. p.203-213.

McBEAN, E. A.; ROVERS, E.A.; FARQUHAR, G. J. Solid Waste Landfill Engineering and Design. In: Prentice Hall. 521p. 1995.

MENEZES, D.B. (1995). Diagnóstico dos impactos do depósito de resíduos sólidos de São Carlos-SP, no meio físico. 103p. Dissertação (Mestrado) - Escola de Engenharia de São Carlos, Universidade de São Paulo, São Carlos. 1995.

NASCIMENTO, M.C.B. (2001). Seleção de sítios visando à implantação de aterros sanitários com base em critérios geológicos, geomorfológicos e hidrológicos. 137p. Dissertação (Mestrado) - Instituto de Geociências, Universidade de São Paulo, São Paulo. 2001.

NOGUEIRA, J.B. (1995). Ensaios de laboratório em mecânica dos solos. São Carlos: EESC/USP.

OLIVEIRA, J.C.; PRIM,E.C.C.; CASTILHOS JR., A.B. (2001). Estudo da retenção de poluentes por lixiviados de aterrros sanitários em solos argilosos. In: Alternativas de 
disposição de resíduos sólidos urbanos para pequenas comunidades: coletânea de trabalhos técnicos. São Carlos: Suprema. p.77-84.

, OLIVEIRA, S. (2001). Determinação de alguns parâmetros indicadores de poluição por efluente líquido de um aterro sanitário. 84p. Tese (Doutorado) - Faculdade de Ciências Agronômicas, Universidade Estadual Paulista, Botucatu. 2001.

OLIVEIRA, S.H. (2002). Avaliação do uso de borra oleosa processada em sistemas de impermeabilização de aterros. 159p. Dissertação (Mestrado) - Pontifícia Universidade Católica do Rio de Janeiro, Rio de Janeiro. 2002.

OLIVEIRA, F. J. S.; JUCÁ, J. F. T. (2004). Acúmulo de metais pesados e Capacidade de impermeabilização do solo imediatamente abaixo de uma célula de um aterro sanitário de resíduos sólidos. Revista Engenharia Sanitária Ambiental. Vol. 9, n. 3, p. $211-217$.

PASCHOALATO, C.F.P.R. (2000). Caracterização dos líquidos percolados por disposição de lixo urbano em diferentes sistemas de aterramento. 97p. Dissertação (Mestrado) - Escola de Engenharia de São Carlos, Universidade de São Paulo, São Carlos. 2000.

- PEJÓN, O.J. (1992). Mapeamento geotécnico regional da Folha de Piracicaba (Esc. 1: 100.000): estudos de aspectos metodológicos, de caracterização e de apresentação de atributos. 2v. Tese (Doutorado) - Escola de Engenharia de São Carlos, Universidade de São Paulo, São Carlos. 1992.

, ROSS, W.R. (1990). Factors influencing the chemical characteristics of landifill leachates. Water $S A$, Pretoria, v.16, n.4, p.275-280, Oct.

, ROWE, R.K.; QUIGLEY, R.M.; BOOKER, J.R. (1995). Clayey barrier systems for waste disposal facilities. London: E \& FN Spon.

,SALA, G. M.; GASPARETTO, N.V.L.; SANTOS, M. L.(1996). Avaliação dos teores de metais pesados em decorrência do uso do solo na Bacia Hidrográfica do Ribeirão Maringá-PR. In: X Simpósio Brasileiro de Geografia física Aplicada.p. 1 - 6. (E33.4T096).

Disponível

em:

$>$ Acessado em: 27

out. 2004.

SANCHEZ, L.E. (2001). Desengenharia: o passivo ambiental na desativação de empreendimentos industriais. São Paulo: EDUSP.

SÃO PAULO (Estado). Governo do Estado de São Paulo (2004). São Paulo em números. Disponível em: $<$ http://www.saopaulo.sp.gov.br/invista/numeros/index.htm>. Acesso em: 24 abr. 2004. 
' SCHALCH, V. (1984). Produção e características do chorume em processo de decomposição do lixo urbano. 103p. Dissertação (Mestrado) - Escola de Engenharia de São Carlos, Universidade de São Paulo, São Carlos. 1984.

SCHALCH, V. (1992). Análise comparativa do comportamento dos aterros sanitários e correlação dos parâmetros do processo de digestão anaeróbia. 219p. Tese (Doutorado) - Escola de Engenharia de São Carlos, Universidade de São Paulo, São Carlos. 1992.

SHARMA, H. D.; LEWIS, S.P. (1994). Waste Containment Systems, Waste stabilization and Landfills: design and evaluation. Copyright John Wiley and Sons, Inc. $58 \mathrm{p}$.

- TCHOBANOGLOUS, G.; THEISEN, H.; VIGIL, S.A. (1993). Integrated solid waste management: engineering principles and management issues. New York: McGraw-Hill.

THORNTON, S.F.; TELLAM, J.H.; LERNER, D.N. (2000). Attenuation of landfill leachate by UK triassic sandstone aquifer materials: 1. Fate of inorganic pollutants in laboratoty columns. Journal of Contaminant Hydrology, Amsterdam, n.43, n.3/4, p.327-354, May.

TONNAER, H. et al. (1998). Natural attenuation: a basis for developing extensive remediation concepts. In: INTERNATIONAL FZK/INO CONFERENCE CONTAMINATED SOIL, 6., 1998, Edinburgh. Proceedings... London: Thomas Telford. v.1, p.191-196.

TRESSOLDI, M. (1991). Contribuição e caracterização de maciços rochosos fraturados visando a proposição de modelos para fins hidrogeológicos $e$ hidrogeotécnicos. 168p. Dissertação (Mestrado) - Instituto de Geociências, Universidade de São Paulo, São Paulo. 1991.

TRESSOLDI, M.(2002). Proposições para investigação de parâmetros controladores da contaminação do subsolo e das águas subterrâneas. 241p. Tese (Doutorado) Escola Politécnica, Universidade de São Paulo São Paulo, 2002.

TUXEN, N. et al. (2000). Fate of seven pesticides in an aerobic aquifer studied in column experiments. Chemosphere, Oxford, v.41, n.9, p.1485-1494, Nov.

, VAN RAIJ, B. (1991). Fertilidade do solo e adubação. Piracicaba: Ceres.

, VIEIRA, L.S. (1975). Manual da ciência do solo. São Paulo: Agronômica Ceres.

YONG, R.N.; MOHAMED, A.M.O.; WARKENTIN, B.P. (1992). Principles of contaminant transport in soils. Amsterdam: Elsevier. (Developments in Geotechnical Engineering, 73). 
YONG, R.N. et al. (2001). Partitioning of heavy metals on soil samples from column $Q$ testes. Engineering Geology, Amsterdam, v.60, n.11/4, p.307-322, June. 
APÊNDICE 
APÊNDICE A - Dados de monitoramento dos parâmetros físico-químicos dos efluentes nos 5,0 VP percolados na Coluna 1

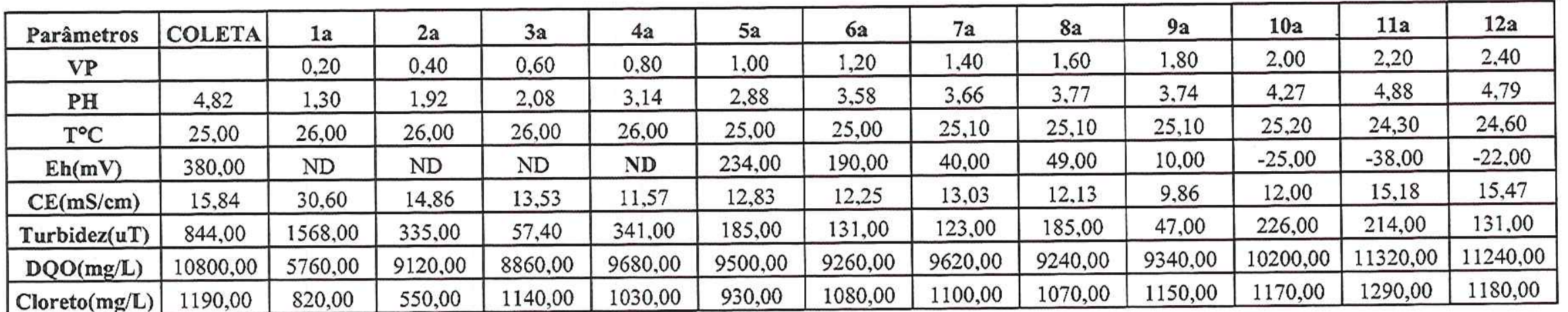

ND - Não Determinado

APÊNDICE A - Dados de monitoramento dos parâmetros físico-químicos dos efluentes nos 5,0 VP percolados na Coluna 1 (continuação)

\begin{tabular}{|c|c|c|c|c|c|c|c|c|c|c|c|c|c|}
\hline Parâmetros & $13 \mathrm{a}$ & $14 a$ & $15 \mathrm{a}$ & $16 \mathrm{a}$ & $17 \mathrm{a}$ & $18 \mathrm{a}$ & $19 a$ & $20 \mathrm{a}$ & $21 \mathrm{a}$ & $22 \mathrm{a}$ & $23 a$ & $24 a$ & $\begin{array}{c}\text { COLETA } \\
\text { FIM }\end{array}$ \\
\hline VP & 2,60 & 2,80 & 3,00 & 3,20 & 3,40 & 3.60 & 3,80 & 4,00 & 4,20 & 4,40 & 4,60 & 5,00 & Ch. Final \\
\hline PH & 4,86 & 4,76 & 3.65 & 4,83 & 4,07 & 4,16 & 4,62 & 4,76 & 4,44 & 3,21 & 4,76 & 4,24 & 2,08 \\
\hline $\mathrm{T}^{\circ} \mathrm{C}$ & 26,40 & 25,80 & 25,80 & 26,40 & 27,90 & 26,60 & 26,70 & 27,60 & 26,20 & 25,70 & 26,00 & 26,00 & 25,00 \\
\hline $\mathrm{Eh}(\mathrm{mV})$ & $-20,00$ & $-64,00$ & $-116,00$ & $-123,00$ & $-128,00$ & $-126,00$ & $-176,00$ & $-177,00$ & $-180,00$ & $-155,00$ & $-134,00$ & $-155,00$ & 60,00 \\
\hline $\mathrm{CE}(\mathrm{mS} / \mathrm{cm})$ & 14,70 & 14,12 & 15,12 & 13,44 & 14,06 & 13,67 & 13,36 & 12,81 & 13,10 & 13,77 & 13,05 & 13,06 & 19,27 \\
\hline Turbidez(uT) & 207,00 & 60,00 & 717,00 & 894,00 & 985,00 & 858,00 & 794,00 & 410,00 & 672,00 & 623,00 & 317,00 & 340,00 & 647,00 \\
\hline $\mathrm{DQO}(\mathrm{mg} / \mathrm{L})$ & 9060,00 & 9040,00 & 8820,00 & 7760,00 & 7240,00 & 7840,00 & 7540,00 & 7100,00 & 7460,00 & 7300,00 & 6860,00 & 7440,00 & 11040,00 \\
\hline Cloreto $(\mathrm{mg} / \mathrm{L})$ & 1220,00 & 1180,00 & 1040,00 & 1060,00 & 1060,00 & 1230,00 & 1320,00 & 1090,00 & 1310,00 & 1210,00 & 1110,00 & 1050,00 & 1190,00 \\
\hline
\end{tabular}


APÊNDICE B - Dados de monitoramento dos parâmetros físico-químicos dos efluentes nos 5,0 VP percolados na Coluna 2

\begin{tabular}{|c|c|c|c|c|c|c|c|c|c|c|c|c|c|}
\hline Parâmetros & COLETA & $1 \mathrm{~b}$ & $2 b$ & $3 b$ & $4 b$ & $5 b$ & $6 \mathrm{~b}$ & $7 \mathrm{~b}$ & $8 b$ & $9 \mathrm{~b}$ & $10 \mathrm{~b}$ & $11 \mathrm{~b}$ & $12 \mathrm{~b}$ \\
\hline VP & & 0,20 & 0,40 & 0,60 & 0,80 & 1,00 & 1,20 & 1,40 & 1,60 & 1,80 & 2,00 & 2,20 & 2,40 \\
\hline PH & 4,82 & 1,32 & 1,54 & 1,82 & 2,58 & 2,08 & 4,08 & 5,01 & 3,84 & 3,82 & 4,10 & 4,39 & 3,98 \\
\hline $\mathrm{T}^{\circ} \mathrm{C}$ & 25,00 & 26,00 & 26,00 & 26,00 & 26,00 & 25,10 & 25,10 & 25,20 & 25,10 & 25,30 & 25,40 & 24,30 & 24,60 \\
\hline $\mathrm{Eh}(\mathrm{mV})$ & 380,00 & ND & ND & $\mathrm{ND}$ & ND & 263,00 & 235,00 & 191,00 & 78,00 & 0,00 & 4,00 & $-17,00$ & 4,00 \\
\hline $\mathrm{CE}(\mathrm{mS} / \mathrm{cm})$ & 15,84 & 29,70 & 20,80 & 17,45 & 12,80 & 15,63 & 12,34 & 11,48 & 12,56 & 13,04 & 12,98 & 13,18 & 13,71 \\
\hline Turbidez(uT) & 844,00 & 1362,00 & 721,00 & 41,30 & 173,00 & 94.50 & 101,00 & 167,00 & 98,60 & 92,30 & 187,00 & 129,00 & 115,00 \\
\hline $\mathrm{DQO}(\mathrm{mg} / \mathrm{L})$ & 10800,00 & 5440,00 & 8620,00 & 10040,00 & 9880,00 & 10040,00 & 10120,00 & 9620,00 & 8980,00 & 8960,00 & 8840,00 & 9260,00 & 8340,00 \\
\hline Cloreto $(\mathrm{mg} / \mathrm{L})$ & 1190,00 & 880,00 & 1310,00 & 1210,00 & 1130,00 & 1130,00 & 1180,00 & 1160,00 & 1090,00 & 1100,00 & 1090,00 & 1040,00 & 1020,00 \\
\hline
\end{tabular}

ND - Não Determinado

APÊNDICE B - Dados de monitoramento dos parâmetros físico-químicos dos efluentes nos 5,0 VP percolados na Coluna 2 (continuação)

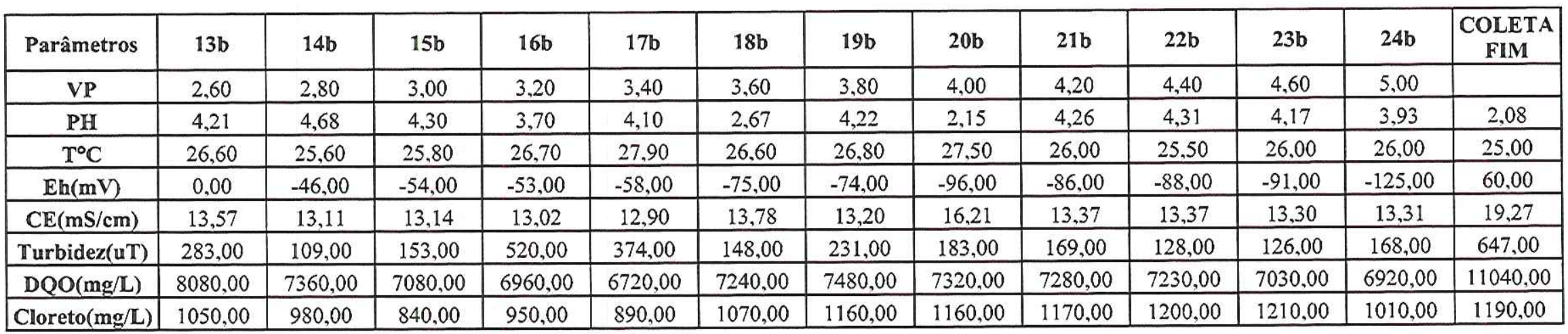


APÊNDICE C - Concentração de metais nos efluentes coletados a cada 0,2 VP na Coluna 1

\begin{tabular}{|c|c|c|c|c|c|c|c|c|c|c|c|c|}
\hline VP & $\mathrm{pH}$ & Eh & $\mathrm{Zn}$ & $\mathrm{Zn} \mathrm{r}$ & $\mathrm{Pb}$ & $\mathrm{Pb} \mathrm{r}$ & $\mathrm{Cd}$ & $\mathrm{Cd} \mathbf{r}$ & $\mathrm{Fe}$ & $\mathrm{Fer}$ & $\mathrm{Mn}$ & $\mathrm{Mn} \mathrm{r}$ \\
\hline 0,0 & 4,82 & 380 & 3,674 & & 5,340 & & 5,300 & & 85,600 & & 19,000 & \\
\hline 0,2 & 1,3 & ND & 0,907 & 0,247 & 0,090 & 0,017 & 0,000 & 0,000 & 60,400 & 0,706 & 6,410 & 0,337 \\
\hline 0,4 & 1,92 & $\mathrm{ND}$ & 0,627 & 0,171 & 0,060 & 0,011 & 0,000 & 0,000 & 13,900 & 0,162 & 2,230 & 0,117 \\
\hline 0,6 & 2,08 & ND & 0,539 & 0,147 & 0,040 & 0,007 & 0,000 & 0,000 & 2,530 & 0,030 & 2,030 & 0,107 \\
\hline 0,8 & 3,14 & ND & 0,438 & 0,119 & 0,040 & 0,007 & 0,000 & 0,000 & 9,200 & 0,107 & 1,800 & 0,095 \\
\hline 1,0 & 2,88 & 234 & 0,622 & 0,169 & 0,040 & 0,007 & 0,000 & 0,000 & 6,300 & 0,074 & 1,250 & 0,066 \\
\hline 1,2 & 3,58 & 190 & 0,401 & 0,109 & 0,030 & 0,006 & 0,000 & 0,000 & 4,250 & 0,050 & 1,180 & 0,062 \\
\hline 1,4 & 3,66 & 40 & 0,304 & 0,083 & 0,110 & 0,021 & 0,000 & 0,000 & 3,230 & 0,038 & 0,790 & 0,042 \\
\hline 1,6 & 3,77 & 49 & 0,383 & 0,104 & 0,200 & 0,037 & 0,000 & 0,000 & 5,440 & 0,064 & 1,020 & 0,054 \\
\hline 1,8 & 3,74 & 10 & 0,281 & 0,077 & 0,190 & 0,036 & 0,000 & 0,000 & 1,500 & 0,018 & 1,040 & 0,055 \\
\hline 2,0 & 4,27 & -25 & 0,309 & 0,084 & 0,170 & 0,032 & 0,000 & 0,000 & 6,160 & 0,072 & 1,070 & 0,056 \\
\hline 2,2 & 4,88 & -38 & 0,373 & 0,102 & 0,130 & 0,024 & 0,020 & 0,004 & 5,870 & 0,069 & 1,180 & 0,062 \\
\hline 2,4 & 4,79 & -22 & 0,166 & 0,045 & 0,110 & 0,021 & 0,040 & 0,008 & 3,720 & 0,043 & 1,190 & 0,063 \\
\hline 2,6 & 4,86 & -20 & 0,092 & 0,025 & 0,120 & 0,022 & 0,030 & 0,006 & 4,640 & 0,054 & 1,050 & 0,055 \\
\hline 2,8 & 4,76 & -64 & 0,092 & 0,025 & 0,170 & 0,032 & 0,030 & 0,006 & 1,720 & 0,020 & 1,000 & 0,053 \\
\hline 3,0 & 3,65 & -116 & 0,092 & 0,025 & 0,150 & 0,028 & 0,020 & 0,004 & 25,500 & 0,298 & 1,090 & 0,057 \\
\hline 3,2 & 4,83 & -123 & 0,124 & 0,034 & 0,190 & 0,036 & 0,160 & 0,030 & 14,800 & 0,173 & 1,640 & 0,086 \\
\hline 3,4 & 4,07 & -128 & 0,129 & 0,035 & 0,160 & 0,030 & 0,070 & 0,013 & 4,740 & 0,055 & 1,400 & 0,074 \\
\hline 3,6 & 4,16 & -126 & 0,258 & 0,070 & 0,200 & 0,037 & 0,050 & 0,009 & 5,430 & 0,063 & 0,950 & 0,050 \\
\hline 3,8 & 4,62 & -176 & 0,447 & 0,122 & 0,230 & 0,043 & 0,050 & 0,009 & 8,760 & 0,102 & 1,200 & 0,063 \\
\hline 4,0 & 4,76 & -177 & 0,369 & 0,100 & 0,080 & 0,015 & 0,040 & 0,008 & 8,480 & 0,099 & 1,270 & 0,067 \\
\hline 4,2 & 4,44 & -180 & 0,235 & 0,064 & 0,200 & 0,037 & 0,220 & 0,042 & 8,430 & 0,098 & 1,950 & 0,103 \\
\hline 4,4 & 3,21 & -155 & 0,231 & 0,063 & 0,200 & 0,037 & 0,140 & 0,026 & 15,600 & 0,182 & 2,840 & 0,149 \\
\hline 4,6 & 4,76 & -134 & 0,267 & 0,073 & 0,290 & 0,054 & 0,120 & 0,023 & 12,900 & 0,151 & 2,760 & 0,145 \\
\hline 4,8 & 4,24 & -155 & 0,207 & 0,056 & 0,050 & 0,009 & 0,050 & 0,009 & 16,100 & 0,188 & 2,660 & 0,140 \\
\hline 5,0 & 4,24 & -155 & 0,207 & 0,056 & 0,050 & 0,009 & 0,050 & 0,009 & 16,100 & 0,188 & 2,660 & 0,140 \\
\hline
\end{tabular}

ND - Não Determinado 
APÊNDICE C - Concentração de metais nos efluentes coletados a cada 0,2 VP na Coluna 1 (continuação)

\begin{tabular}{|c|c|c|c|c|c|c|c|c|c|c|c|c|}
\hline VP & $\mathrm{pH}$ & $\mathbf{E h}$ & $\mathrm{Cu}$ & $\mathrm{Cu} \mathrm{r}$ & $\mathrm{Cr}$ & $\mathrm{Cr} \mathbf{r}$ & $\mathrm{Na}$ & $\mathrm{Na} \mathrm{r}$ & $\mathbf{K}$ & $\mathbf{K r}$ & $\mathrm{Ni}$ & Ni $r$ \\
\hline 0,0 & 4,82 & 380 & 1,253 & & 9,100 & & 1190,000 & & 1170,000 & & 0,200 & \\
\hline 0.2 & 1,3 & $\mathrm{ND}$ & 1,190 & 0,949 & 0,000 & 0,000 & 288,600 & 0,243 & 43,200 & 0,037 & 0,009 & 0,045 \\
\hline 0,4 & 1,92 & ND & 1,539 & 1,228 & 0,000 & 0,000 & 876,500 & 0,737 & 308,500 & 0,264 & 0,009 & 0,045 \\
\hline 0,6 & 2,08 & ND & 1,665 & 1,329 & 0,000 & 0,000 & 902,500 & 0,758 & 341,700 & 0,292 & 0,009 & 0,045 \\
\hline 0,8 & 3,14 & $\mathrm{ND}$ & 1,451 & 1,158 & 0,000 & 0,000 & 987,000 & 0,829 & 598,000 & 0,511 & 0,009 & 0,045 \\
\hline 1,0 & 2,88 & 234 & 1,467 & 1,171 & 0,000 & 0,000 & 1110,600 & 0,933 & 757,200 & 0,647 & 0,050 & 0,250 \\
\hline 1,2 & 3,58 & 190 & 1,602 & 1,278 & 0,000 & 0,000 & 1117,000 & 0,939 & 779,000 & 0,666 & 0,050 & 0,250 \\
\hline 1,4 & 3,66 & 40 & 1,118 & 0,892 & 0,000 & 0,000 & 1143,000 & 0,961 & 836,700 & 0,715 & 0,009 & 0,045 \\
\hline 1,6 & 3,77 & 49 & 2,799 & 2,234 & 0,000 & 0,000 & 1195,200 & 1,004 & 947,000 & 0,809 & 0,080 & 0,400 \\
\hline 1,8 & 3,74 & 10 & 5,440 & 4,342 & 0,000 & 0,000 & 974,000 & 0,818 & 909,000 & 0,777 & 0,009 & 0,045 \\
\hline 2,0 & 4,27 & -25 & 4,813 & 3,841 & 0,000 & 0,000 & 1052,000 & 0,884 & 974,000 & 0,832 & 0,070 & 0,350 \\
\hline 2,2 & 4,88 & -38 & 1,983 & 1,582 & 0,000 & 0,000 & 805,000 & 0,676 & 706,600 & 0,604 & 0,110 & 0.550 \\
\hline 2,4 & 4,79 & -22 & 0,960 & 0,766 & 0,000 & 0,000 & 648,800 & 0,545 & 583,700 & 0,499 & 0,120 & 0,600 \\
\hline 2,6 & 4,86 & -20 & 0,952 & 0.759 & 0,000 & 0,000 & 453,700 & 0,381 & 417,400 & 0,357 & 0,090 & 0,450 \\
\hline 2,8 & 4,76 & -64 & 0,706 & 0,563 & 0,000 & 0,000 & 1169,200 & 0,983 & 1162,000 & 0,993 & 0,060 & 0,300 \\
\hline 3.0 & 3,65 & -116 & 0,849 & 0,677 & 0,000 & 0,000 & 1025,000 & 0,861 & 1060,000 & 0,906 & 0,070 & 0,350 \\
\hline 3,2 & 4,83 & -123 & 1,197 & 0,956 & 0,000 & 0,000 & 950,000 & 0,798 & 980,000 & 0,838 & 0,050 & 0,250 \\
\hline 3.4 & 4,07 & -128 & 1,332 & 1,063 & 0,000 & 0,000 & 980,000 & 0,824 & 1010,000 & 0,863 & 0,100 & 0,500 \\
\hline 3,6 & 4,16 & -126 & 1,324 & 1.057 & 0,000 & 0,000 & 935,000 & 0,786 & 985,000 & 0,842 & 0,140 & 0,700 \\
\hline 3,8 & 4,62 & -176 & 1,483 & 1,183 & 0,000 & 0,000 & 930,000 & 0,782 & 975,000 & 0,833 & 0,160 & 0,800 \\
\hline 4,0 & 4,76 & -177 & 1,610 & 1,285 & 0,000 & 0,000 & 895,000 & 0,752 & 945,000 & 0,808 & 0,110 & 0,550 \\
\hline 4,2 & 4,44 & -180 & 1,824 & 1,456 & 0,000 & 0,000 & 900,000 & 0,756 & 930,000 & 0,795 & 0,120 & 0,600 \\
\hline 4,4 & 3,21 & -155 & 1,840 & 1,468 & 0,000 & 0,000 & 920,000 & 0,773 & 940,000 & 0,803 & 0,110 & 0,550 \\
\hline 4,6 & 4,76 & -134 & 1,887 & 1.506 & 0,000 & 0,000 & 900,000 & 0,756 & 925,000 & 0.791 & 0,130 & 0,650 \\
\hline 4,8 & 4,24 & -155 & 1,443 & 1,152 & 0,000 & 0,000 & 915,000 & 0,769 & 950,000 & 0,812 & 0,040 & 0,200 \\
\hline 5,0 & 4,24 & -155 & 1,443 & 1,152 & 0,000 & 0,000 & 915,000 & 0,769 & 950,000 & 0,812 & 0,040 & 0,200 \\
\hline
\end{tabular}

ND - Não Determinado 
APÊNDICE D - Concentração de metais nos efluentes coletados a cada 0,2 VP na Coluna 2

\begin{tabular}{|c|c|c|c|c|c|c|c|c|c|c|c|c|}
\hline VP & $\mathrm{pH}$ & $\mathbb{E h}$ & $\mathrm{Zn}$ & $\mathrm{Zn} \mathrm{r}$ & $\mathbf{P b}$ & $\mathrm{Pb} \mathrm{r}$ & $\mathrm{Cd}$ & $\mathrm{Cd} \mathrm{r}$ & $\mathrm{Fe}$ & Fer $r$ & $\mathrm{Mn}$ & Mn $r$ \\
\hline 0,0 & 4,82 & 380,0 & 3,674 & & 5,340 & & 5,300 & & 85,600 & & 19,000 & \\
\hline 0.2 & 1,32 & ND & 1,438 & 0,392 & 0,050 & 0,009 & 0,006 & 0,001 & 48,600 & 0,568 & 6,550 & 0,345 \\
\hline 0,4 & 1,54 & ND & 0,798 & 0,217 & 0,030 & 0,006 & 0,006 & 0,001 & 25,600 & 0,299 & 4,310 & 0,227 \\
\hline 0,6 & 1,82 & ND & 1,397 & 0,380 & 0,040 & 0,007 & 0,006 & 0,001 & 2,380 & 0,028 & 1,060 & 0,056 \\
\hline 0,8 & 2,58 & ND & 1,766 & 0,481 & 0,070 & 0,013 & 0,006 & 0,001 & 5,850 & 0,068 & 0,980 & 0,052 \\
\hline 1,0 & 2,08 & 263,0 & 0,535 & 0,146 & 0,070 & 0,013 & 0,006 & 0,001 & 3,240 & 0,038 & 0,960 & 0,051 \\
\hline 1,2 & 4,08 & 235,0 & 0,134 & 0,036 & 0,070 & 0,013 & 0,010 & 0,002 & 3,120 & 0,036 & 0,880 & 0,046 \\
\hline 1,4 & 5,01 & 191,0 & 0,157 & 0,043 & 0,120 & 0,022 & 0,010 & 0,002 & 4,870 & 0,057 & 1,020 & 0,054 \\
\hline 1,6 & 3,84 & 78,0 & 0,198 & 0,054 & 0,090 & 0,017 & 0,006 & 0,001 & 2,890 & 0,034 & 0,900 & 0,047 \\
\hline 1,8 & 3,82 & 0,0 & 0,166 & 0,045 & 0,100 & 0,019 & 0,010 & 0,002 & 2,780 & 0,032 & 0,960 & 0,051 \\
\hline 2,0 & 4,10 & 4,0 & 0,180 & 0,049 & 0,090 & 0,017 & 0,020 & 0,004 & 5,120 & 0,060 & 0,960 & 0,051 \\
\hline 2,2 & 4,39 & $-17,0$ & 0,055 & 0,015 & 0,170 & 0,032 & 0,020 & 0,004 & 2,950 & 0,034 & 1,160 & 0,061 \\
\hline 2,4 & 3,98 & 4,0 & 0,055 & 0,015 & 0,060 & 0,011 & 0,006 & 0,001 & 2,380 & 0,028 & 0,930 & 0,049 \\
\hline 2,6 & 4,21 & 0,0 & 0,069 & 0,019 & 0,120 & 0,022 & 0,020 & 0,004 & 6,120 & 0,071 & 1,120 & 0,059 \\
\hline 2,8 & 4,68 & $-46,0$ & 0,055 & 0,015 & 0,180 & 0,034 & 0,020 & 0,004 & 3,000 & 0,035 & 1,020 & 0,054 \\
\hline 3,0 & 4,30 & $-54,0$ & 0,083 & 0,023 & 0,130 & 0,024 & 0,020 & 0,004 & 5,650 & 0,066 & 1,020 & 0,054 \\
\hline 3,2 & 3,70 & $-53,0$ & 0,138 & 0,038 & 0,100 & 0,019 & 0,030 & 0,006 & 18,900 & 0,221 & 1,020 & 0,054 \\
\hline 3.4 & 4,10 & $-58,0$ & 0,055 & 0,015 & 0,160 & 0,030 & 0,020 & 0,004 & 6,970 & 0,081 & 1,090 & 0,057 \\
\hline 3.6 & 2,67 & $-75,0$ & 0,161 & 0,044 & 0,170 & 0,032 & 0,030 & 0,006 & 4,470 & 0,052 & 1,150 & 0,061 \\
\hline 3,8 & 4,22 & $-74,0$ & 0,300 & 0,082 & 0,290 & 0,054 & 0,030 & 0,006 & 8,460 & 0,099 & 1,230 & 0,065 \\
\hline 4,0 & 2,15 & $-96,0$ & 0,194 & 0,053 & 0,110 & 0,021 & 0,030 & 0,006 & 5,300 & 0,062 & 1,000 & 0,053 \\
\hline 4,2 & 4,26 & $-86,0$ & 0,244 & 0,066 & 0,220 & 0,041 & 0,040 & 0,008 & 6,200 & 0,072 & 1,030 & 0,054 \\
\hline 4,4 & 4,31 & $-88,0$ & 0,244 & 0,066 & 0,160 & 0,030 & 0,040 & 0,008 & 7,570 & 0,088 & 1,430 & 0,075 \\
\hline 4,6 & 4,17 & $-91,0$ & 0,175 & 0,048 & 0,230 & 0,043 & 0,030 & 0,006 & 8.530 & 0,100 & 1,410 & 0,074 \\
\hline 4,8 & 3,93 & $-125,0$ & 0,124 & 0,034 & 0,050 & 0,009 & 0,010 & 0,002 & 12,900 & 0,151 & 1,520 & 0,080 \\
\hline 5,0 & 3,93 & $-125,0$ & 0,124 & 0,034 & 0,050 & 0,009 & 0,010 & 0,002 & 12,900 & 0,151 & 1,520 & 0,080 \\
\hline
\end{tabular}

ND - Não Determinado 
APÊNDICE D - Concentração de metais nos efluentes coletados a cada 0,2 VP na Coluna 2 (continuação)

\begin{tabular}{|c|c|c|c|c|c|c|c|c|c|c|c|c|}
\hline VP & $\mathrm{pH}$ & Eh & $\mathrm{Cu}$ & $\mathrm{Cur}$ & $\mathrm{Cr}$ & $\mathrm{Crr}$ & $\mathrm{Na}$ & $\mathrm{Nar}$ & $\mathbf{K}$ & $\mathrm{Kr}$ & $\mathrm{Ni}$ & Ni $r$ \\
\hline 0,0 & 4,82 & 380,0 & 1,253 & & 9,100 & & 1190,000 & & 1170,000 & & 0,200 & \\
\hline 0,2 & 1,32 & ND & 1,348 & 1,076 & 0,000 & 0,000 & 668,300 & 0,562 & 44,600 & 0,038 & 0,008 & 0.040 \\
\hline 0,4 & 1,54 & ND & 1,840 & 1,468 & 0,000 & 0,000 & 811,400 & 0,682 & 88,000 & 0,075 & 0,008 & 0,040 \\
\hline 0,6 & 1,82 & ND & 1,332 & 1,063 & 0,000 & 0,000 & 1032,600 & 0,868 & 547,500 & 0,468 & 0,008 & 0,040 \\
\hline 0,8 & 2,58 & ND & 1,657 & 1,323 & 0,000 & 0,000 & 941,500 & 0,791 & 525,900 & 0,449 & 0,070 & 0,350 \\
\hline 1,0 & 2,08 & 263,0 & 3,941 & 3,145 & 0,000 & 0,000 & 505,700 & 0,425 & 345,200 & 0,295 & 0,060 & 0,300 \\
\hline 1,2 & 4,08 & 235,0 & 2,316 & 1,848 & 0,000 & 0,000 & 499,200 & 0,419 & 366,800 & 0,314 & 0,040 & 0,200 \\
\hline 1,4 & 5,01 & 191,0 & 2,577 & 2,057 & 0,000 & 0,000 & 518,700 & 0,436 & 424,700 & 0,363 & 0,050 & 0,250 \\
\hline 1,6 & 3,84 & 78,0 & 2,553 & 2,038 & 0,000 & 0,000 & 512,200 & 0,430 & 410,200 & 0,351 & 0,040 & 0,200 \\
\hline 1,8 & 3,82 & 0,0 & 2,110 & 1,684 & 0,000 & 0,000 & 544,700 & 0,458 & 453,600 & 0,388 & 0,060 & 0,300 \\
\hline 2,0 & 4,10 & 4,0 & 3,100 & 2,474 & 0,000 & 0,000 & 499,200 & 0,419 & 410,200 & 0,351 & 0,120 & 0,600 \\
\hline 2,2 & 4,39 & $-17,0$ & 1,031 & 0,823 & 0,000 & 0,000 & 940,000 & 0,790 & 905,000 & 0,774 & 0,040 & 0,200 \\
\hline 2,4 & 3,98 & 4,0 & 1.047 & 0,835 & 0,000 & 0,000 & 980,000 & 0,824 & 915,000 & 0,782 & 0,008 & 0.040 \\
\hline 2,6 & 4,21 & 0,0 & 1,031 & 0,823 & 0,000 & 0,000 & 960,000 & 0,807 & 965,000 & 0,825 & 0,090 & 0,450 \\
\hline 2,8 & 4,68 & $-46,0$ & 1,031 & 0,823 & 0,000 & 0,000 & 915,000 & 0,769 & 925,000 & 0,791 & 0,080 & 0,400 \\
\hline 3,0 & 4,30 & $-54,0$ & 0,904 & 0,721 & 0,000 & 0,000 & 915,000 & 0,769 & 930,000 & 0,795 & 0,060 & 0,300 \\
\hline 3,2 & 3,70 & $-53,0$ & 1,269 & 1,013 & 0,000 & 0,000 & 895,000 & 0,752 & 920,000 & 0,786 & 0,050 & 0,250 \\
\hline 3,4 & 4,10 & $-58,0$ & 1,229 & 0,981 & 0,000 & 0,000 & 885,000 & 0,744 & 905,000 & 0,774 & 0,050 & 0,250 \\
\hline 3.6 & 2,67 & $-75,0$ & 1,530 & 1,221 & 0,000 & 0,000 & 885,000 & 0,744 & 905,000 & 0,774 & 0.060 & 0,300 \\
\hline 3,8 & 4,22 & $-74,0$ & 1,293 & 1,032 & 0,000 & 0,000 & 875,000 & 0,735 & 890,000 & 0,761 & 0,110 & 0,550 \\
\hline 4,0 & 2,15 & $-96,0$ & 1,998 & 1,595 & 0,000 & 0,000 & 885,000 & 0,744 & 905,000 & 0,774 & 0,130 & 0,650 \\
\hline 4,2 & 4,26 & $-86,0$ & 2,553 & 2,038 & 0,000 & 0,000 & 910,000 & 0,765 & 920,000 & 0,786 & 0,150 & 0,750 \\
\hline 4,4 & 4,31 & $-88,0$ & 1,975 & 1,576 & 0,000 & 0,000 & 905,000 & 0,761 & 940,000 & 0,803 & 0,110 & 0,550 \\
\hline 4,6 & 4,17 & $-91,0$ & 1,824 & 1,456 & 0,000 & 0,000 & 920,000 & 0,773 & 940,000 & 0,803 & 0,120 & 0,600 \\
\hline 4,8 & 3,93 & $-125,0$ & 0,967 & 0,772 & 0,000 & 0,000 & 910,000 & 0,765 & 950,000 & 0,812 & 0,008 & 0,040 \\
\hline 5,0 & 3,93 & $-125,0$ & 0,967 & 0,772 & 0,000 & 0,000 & 910,000 & 0,765 & 950,000 & 0,812 & 0,008 & 0,040 \\
\hline
\end{tabular}

ND - Não Determinado 
APÊNDICE E - Dados dos Perfis de retenção de metais pesados pelas colunas 1,2 e 3

COLUNA 1

\begin{tabular}{ccccccccc}
\hline Prof.(mm) & $\mathbf{Z n}$ & $\mathbf{P b}$ & $\mathbf{C d}$ & $\mathbf{F e}$ & $\mathbf{M n}$ & $\mathbf{C u}$ & $\mathbf{N i}$ & $\mathbf{C r}$ \\
\hline 900 & 4,50 & 22,00 & 31,00 & 5650,00 & 56,00 & 204,00 & 0,40 & 20,50 \\
750 & 6,00 & 11,00 & 13,50 & 5200,00 & 54,50 & 190,00 & 0,40 & 15,00 \\
600 & 8,50 & 8,50 & 4,50 & 4430,00 & 37,00 & 178,50 & 0,40 & 6,00 \\
450 & 24,50 & 7,00 & 0,03 & 4375,00 & 35,50 & 156,50 & 0,40 & 2,50 \\
300 & 28,50 & 6,00 & 0,00 & 4200,00 & 33,00 & 147,00 & 0,40 & 1,00 \\
150 & 71,50 & 5,50 & 0,00 & 3710,00 & 24,00 & 133,50 & 0,40 & 0,25 \\
\hline
\end{tabular}

COLUNA 2

\begin{tabular}{ccccccccc}
\hline Prof.(mm) & Zn & Pb & Cd & Fe & Mn & Cu & Ni & Cr \\
\hline 900 & 1,00 & 22,00 & 30,00 & 5550,00 & 66,50 & 178,50 & 0,40 & 17,50 \\
750 & 4,50 & 17,00 & 18,00 & 4740,00 & 46,00 & 168,50 & 0,40 & 10,50 \\
600 & 12,00 & 10,00 & 2,00 & 4610,00 & 31,00 & 151,50 & 0,40 & 5,10 \\
450 & 22,00 & 6,00 & 0,03 & 4485,00 & 28,00 & 145,50 & 0,40 & 2,00 \\
300 & 35,50 & 2,00 & 0,03 & 4225,00 & 25,00 & 134,50 & 0,40 & 0,25 \\
150 & 62,00 & 0,10 & 0,03 & 3475,00 & 20,00 & 120,50 & 0,40 & 0,25 \\
\hline
\end{tabular}

COLUNA 3

\begin{tabular}{ccccccccc}
\hline Prof.(mm) & Zn & Pb & Cd & Fe & Mn & Cu & Ni & Cr \\
\hline 900 & 31,50 & 9,00 & 0,03 & 5300,00 & 28,50 & 70,00 & 0,40 & 5,50 \\
750 & 21,00 & 8,00 & 0,03 & 5000,00 & 25,00 & 70,00 & 0,40 & 5,50 \\
600 & 19,00 & 6,00 & 0,03 & 4850,00 & 23,50 & 60,00 & 0,40 & 5,00 \\
450 & 10,00 & 5,50 & 0,03 & 4800,00 & 22,00 & 60,00 & 0,40 & 5,00 \\
300 & 9,00 & 5,00 & 0,03 & 3165,00 & 21,00 & 60,00 & 0,40 & 5,00 \\
150 & 8,00 & 5,00 & 0,03 & 2920,00 & 16,50 & 152,50 & 0,40 & 0,25 \\
\hline
\end{tabular}

